ELAINE APARECIDA FERNANDES RODRIGUES

\title{
Validação de modelo biomecânico de marcha para uso em testes pré-clínicos com células tronco
}

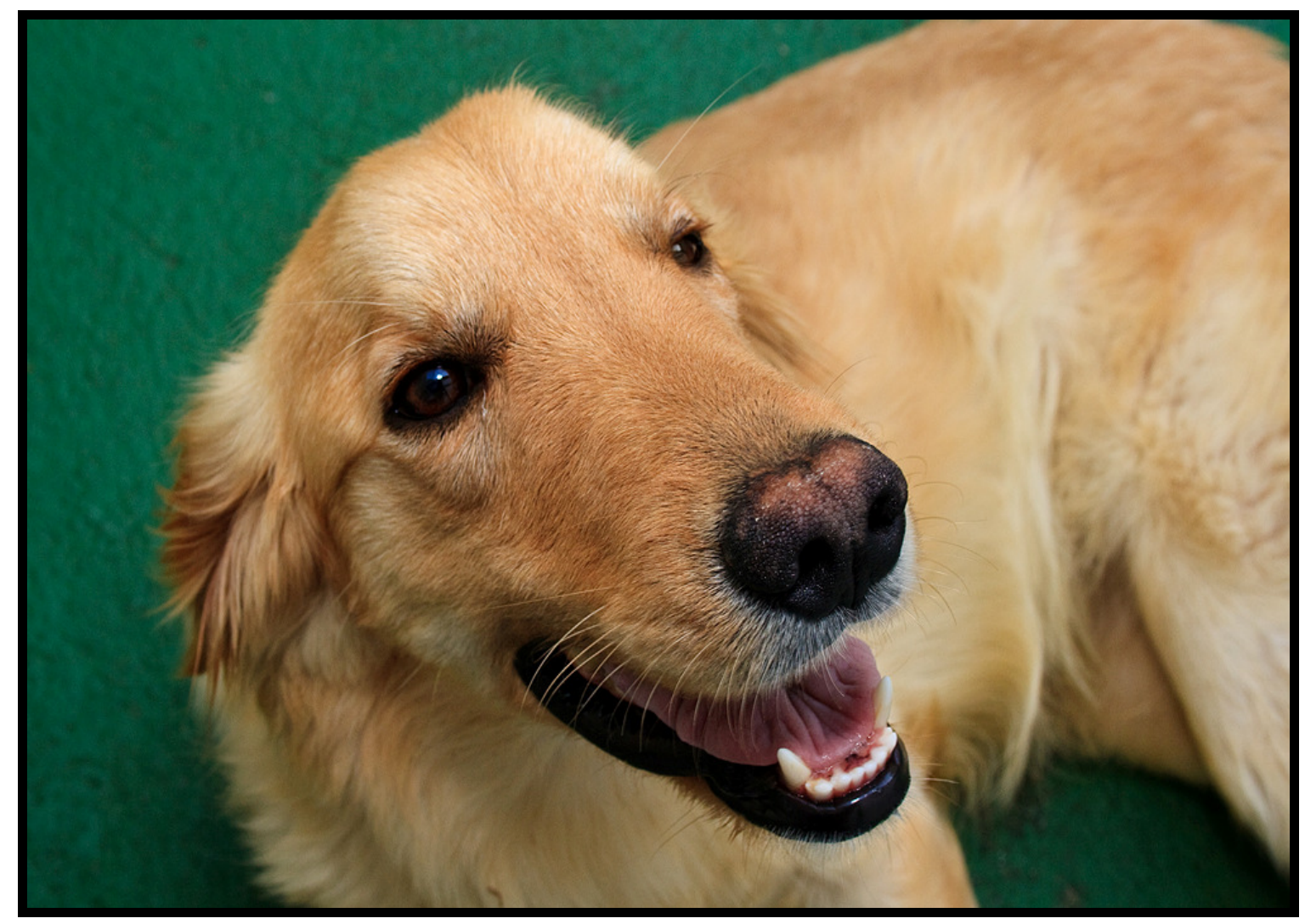

São Paulo 


\title{
Validação de modelo biomecânico de marcha para uso em testes pré-clínicos com células tronco
}

\begin{abstract}
Dissertação apresentada ao Programa de Pós-Graduação em Anatomia dos Animais Domésticos e Silvestres da Faculdade de Medicina Veterinária e Zootecnia da Universidade de São Paulo para obtenção do título de Mestre em Ciências
\end{abstract}

Departamento:

Cirurgia

Área de concentração:

Anatomia dos Animais Domésticos e Silvestres

Orientador:

Prof. Dr. Carlos Eduardo Ambrósio 
Autorizo a reprodução parcial ou total desta obra, para fins acadêmicos, desde que citada a fonte.

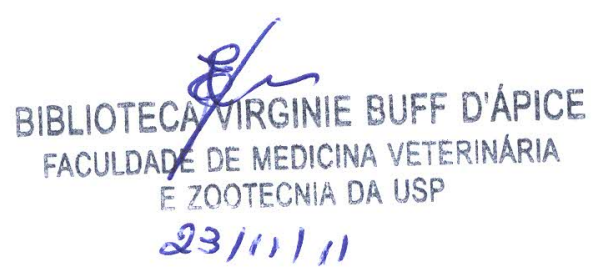

DADOS INTERNACIONAIS DE CATALOGAÇÃO-NA-PUBLICAÇÃO

(Biblioteca Virginie Buff D’Ápice da Faculdade de Medicina Veterinária e Zootecnia da Universidade de São Paulo)

Rodrigues, Elaine Aparecida Fernandes

Validação de modelo biomecânico de marcha para uso em testes pré-clínicos

FMVZ com células tronco / Elaine Aparecida Fernandes Rodrigues. -- 2011

$96 \mathrm{f}$.

Dissertação (Mestrado) - Universidade de São Paulo. Faculdade de Medicina Veterinária e Zootecnia. Departamento de Cirurgia, São Paulo, 2011

Programa de Pós-Graduação: Anatomia dos Animais Domésticos e Silvestres. Área de concentração: Anatomia dos Animais Domésticos e Silvestres.

Orientador: Prof. Dr. Carlos Eduardo Ambrósio.

1. Biomecânica. 2. Marcha. 3. Distrofĩa muscular. I. Titulo. 


\section{CERTIFICADO}

Certificamos que o Projeto intitulado "Validação de modelo biomecânico de marcha para uso em testes pré-clínicos com células-tronco", protocolado sob o $\mathrm{n}^{\circ}$ 1920/2010, sob a responsabilidade do Prof. Dr. Carlos Eduardo Ambrósio, utilizando 8 (oito) cães, está de acordo com os princípios éticos de experimentação animal da "Comissão de Ética no uso de animais" da Faculdade de Medicina Veterinária e Zootecnia da Universidade de São Paulo e foi aprovado em reunião de 07/04/2010.

We certify that the Research "Validation of biomechanical gait model for use in preclinical trials with stem cells", protocol number 1920/2010, utilizing 8 (eight) dogs, under the responsibility Prof. Dr. Carlos Eduardo Ambrósio, agree with Ethical Principles in Animal Research adopted by "Ethic Committee in the use of animals" of the School of Veterinary Medicine and Animal Science of University of São Paulo and was approved in the meeting of day 04/07/2010.

São Paulo, 08 de abril de 2010

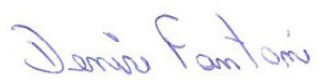

Profa. Dra. Denise Tabacchi Fantoni

Presidente 


\section{FOLHA DE AVALIAÇÃO}

Nome: RODRIGUES, Elaine Aparecida Fernandes

Título: Validação de modelo biomecânico de marcha para uso em testes pré-clínicos com células tronco

Dissertação apresentada ao Programa de Pós-Graduação em Anatomia dos Animais Domésticos e Silvestres da Faculdade de Medicina Veterinária e Zootecnia da Universidade de São Paulo para obtenção do título de Mestre em Ciências

Data:

Banca Examinadora

Prof.Dr.

Instituição:

Prof.Dr.

Instituição:

Prof.Dr.

Instituição: 


\section{DEDICATÓRIA}

A todos os pacientes com distrofia muscular. Que Deus abençoe a vida de cada um de vocês e dê força para superar todos os obstáculos.

Aos amados cães do canil GRMD-Brasil em especial os animais, Monstra, Lola, Gaspar, Luck, Biz e Winner (in memorian) com quem passei maior parte do tempo. Que Deus os protejam sempre. 
Meus amados pais Ubaldino e Marilene. Vocês são os grandes responsáveis por essa conquista, meu maior exemplo de simplicidade, valores e princípios. Obrigada pela confiança, carinho e incentivo.

\section{AMO MUITO VOCÊS!}




\section{Agradecimentos}

Ao Professor Carlos Eduardo Ambrósio, pelo acolhimento e todo apoio nessa pesquisa e na pós-graduação. Obrigada pela orientação, companheirismo, compreensão e até pelas broncas, com certeza elas contribuíram para meu crescimento.

A Professora Thais Gaiad Peixoto Machado, pela disponibilidade e estar sempre me ajudando, socorrendo e tirando dúvidas. Obrigada pelo carinho, e paciência.

A Professora Maria Angélica Miglino, por abrir as portas e me conceder essa oportunidade.

Ao meu amado irmão Fábio e minha cunhada Daniany pelo companheirismo e apoio. Obrigada pelas inúmeras risadas e pelos momentos maravilhosos que dividimos. Que Deus ilumine a vida de vocês nessa nova etapa. Amo vocês irmão e agora minha nova irmãzinha!

A melhor amiga de toda a vida Aline, pelo incentivo de vir para São Paulo, apoio e dedicação. Palavras nunca serão o suficiente para expor o meu respeito, carinho e admiração por você que teve um papel fundamental na minha vida.

As minhas amigas charmosas: Pati, Tati e Paulinha pelo apoio, torcida e sempre estarem do meu lado. Vocês são eternas na minha vida.

A minha amiga Luciana por fazer meu primeiro contato na veterinária $e$ apoio sempre. Você é um grande exemplo amiga.

A companheira de lar e amiga Dilayla Kely por toda ajuda carinho, amizade, risadas, companheirismo dentro e fora da faculdade. Obrigada por me apoiar nos momentos mais difíceis e ter sempre uma palavra de apoio. Amo você amiga!

As minhas flores mais lindas, charmosas e amadas de toda galáxia Renata e Larissa, por todo carinho, dedicação e amizade. Eu amo vocês minhas lindezas que sempre alegram meus dias. 
Aos meus amigos "Isauro dos Bodes" (Marcão), Valdir, e Luiz pela amizade, carinho, confiança, apoio $e$ infinitas conversas "produtivas". E meu caro amigo Sarmento, por estar sempre acabadão e fortalecer os laços todos os dias.

Aos amados Bruno Bertassoli e Delys (Natal) por todas as risadas, brincadeiras, carinho e dedicação. Vocês foram os melhores presentinhos que Papai do céu me enviou esse ano!

Aos amigos, Lucas José e Conrado Vitor, pelas risadas, sustos e companheirismo. Vocês são chatos, mas servem de companhia.

A todos os amigos e colegas de departamento Sílvia (companheira de desabafos; você é meu orgulho amiga!), Thais (você, você, você, você), Marina, Matheus, João Morini, André, Greyson, Phelipinho, Carol Costola, Bruno Vasconcelos, Ana Mançanares, Márcio, Fabiele, Isabela, João Mendonça, Carol Wink, Catarina, Atanásio, Vitória, Amanda, Náthia, Rafael, Érika, Letícia, Graziela, Maria Angélica (pequenininha do mal), Patty Luz, Paulo, (rumo ao best friend) Daniela Bragança, Jodonai (ainda vamos discutir um artigo), Naira, Amilton, Sônia, Dayane e o casal mais boiadeiro Aline Chapolete e Diego Leão pelos momentos de alegria, compartilhados.

Aos amigos conquistados fora da faculdade: Bruna, Wanessa, Gabo, Best, Jovelina, Lê, Flávia e Tina, pelo apoio e companheirismo.

A todo grupo do Canil GRMD-Brasil, pela união nessa luta.

Ao Professor Júlio Cerca Serrão por me receber em seu laboratório, e todo auxílio no desenvolvimento da pesquisa.

Aos professores Daniele Martins, Antônio Assis, José Roberto Kfoury, Patrícia Braga, Pedro Bombonato, Paula Papa, pelas aulas e ensinamentos.

Ao funcionário Augusto pelo cuidado e carinhos com os cães.

Aos funcionários Jaqueline, Maicon, Diogo, İndio, Ronaldo e Fabiana por toda ajuda concedida.

Aos funcionários Bruno e Jaqueline da EEFE-USP, pela paciência e valiosa ajuda na realização dessa pesquisa. Não sei o que seria de mim sem vocês. 
A todos outros, funcionários, colegas e professores que estiveram presentes nessa jornada.

E enfim um agradecimento mais que especial aquele que me concedeu o dom da vida, e está sempre do meu lado, me guiando e protegendo de todo mal:

MUITO OBRIGADA MEU DEUS! 
Agradeço a FAPESP pelo apoio financeiro referente ao processo

2010/03445-5. 


\section{RESUMO}

RODRIGUES, E. A. F. Validação de modelo biomecânico de marcha para uso em testes pré-clinico com células tronco. [Validation of biomechanical model of gait for use in preclinical test with stem cell]. 2011. 96 f. Dissertação (Mestrado em Ciências) Faculdade de Medicina Veterinária e Zootecnia, Universidade de São Paulo, São Paulo, 2011.

A distrofia muscular de Duchenne constitui um distúrbio genético de caráter recessivo e caracteriza-se pela deficiência ou ausência da proteína distrofina na superfície da membrana da célula muscular, podendo acometer a musculatura cardíaca e o sistema nervoso. O cão da raça Golden Retriever afetado pela distrofia muscular (GRDM), é considerado um excelente modelo para o estudo, devido às muitas similaridades entre cães afetados e meninos com distrofia muscular de Duchenne. Sabe-se que os animais do modelo GRMD apresentam fraqueza muscular progressiva, o que gera adaptações importantes na sua marcha. O conhecimento destas adaptações na ausência da musculatura esquelética pode esclarecer a evolução da doença neste modelo, bem como contribuir com uma nova ferramenta de avaliação quantitativa de futuros tratamentos da DMD. Portando este estudo abordou as variáveis da marcha do cão GRDM com o objetivo de estabelecer uma ferramenta de avaliação quantitativa da marcha neste modelo experimental que possa contribuir para futuras pesquisas terapêuticas além de colaborar com o conhecimento e aplicabilidade da biomecânica na marcha animal. Foram utilizados seis animais distróficos selecionados da colônia de cães GRMD Brasil. Foram feitas mensuração dos segmentos corporais, analise cinemáticas através da utilização de imagens e análise dinâmica resultando da utilização de uma plataforma de força. Nos resultados da biometria obtivemos a média dos segmentos corporais dos seis animais estudados: braço: $16,69 \mathrm{~cm}$; antebraço $17,12 \mathrm{~cm}$; carpo $5,16 \mathrm{~cm}$; coxa $18,91 \mathrm{~cm}$; perna $19,03 \mathrm{~cm}$; tarso $10,98 \mathrm{~cm}$; tórax $67.54 \mathrm{~cm}$; altura $52,14 \mathrm{~cm}$; e peso $20,44 \mathrm{~kg}$. Nos resultados referentes à análise cinemática obtivemos o grau de flexão e extensão das seguintes articulações: escapuloumeral (flexão: $121.44^{\circ}$ e extensão $152.76^{\circ}$ ), umeroradioulnar (flexão $121.68^{\circ}$ e extensão $153.24^{\circ}$ ), carpo (flexão $122.2^{\circ}$ e extensão $152.84^{\circ}$ ), coxofemoral (flexão $122.08^{\circ}$ e extensão $153.96^{\circ}$ ), femortibiopatelar (flexão $121.2^{\circ}$ e extensão $151.64^{\circ}$ ), tarso (flexão $121.48^{\circ}$ e extensão $153.44^{\circ}$ ). $\mathrm{Na}$ análise dinâmica obtida através da plataforma de força obtivemos a média dos valores dos picos de força de reação ao solo de cada um dos animais: Biz 141N, Gaspar 128N, Lola $180 \mathrm{~N}, 183 \mathrm{~N}, 150 \mathrm{~N}, 135 \mathrm{~N}$. Com esses resultados podemos concluir que a articulação femortibiopatelar foi a que teve um grau de amplitude maior em relação às outras articulações; os picos de flexão e extensão articular variam de acordo com cada articulação; os picos de flexão e extensão variam mais no membro pélvico do que no membro torácico. Os resultados obtidos podem ser úteis em avaliações pré-clinicas utilizando o modelo canino GRMD.

Palavras-chave: Biomecânica. Marcha. Distrofia muscular. 


\begin{abstract}
RODRIGUES, E. A. F. Validation of biomechanical model of gait for use in preclinical test with stem cell. [Validação de modelo biomecânico de marcha para uso em testes pré-clinico com células tronco]. 2011. 96 f. Dissertação (Mestrado em Ciências) - Faculdade de Medicina Veterinária e Zootecnia, Universidade de São Paulo, São Paulo, 2011.

Duchenne muscular dystrophy is a genetic disorder with a recessive trait and is characterized by a deficiency or absence of dystrophin protein on the membrane surface of muscle cells, affecting the heart muscles and nervous system. The dog Golden Retriever affected by muscular dystrophy (GRDM) is considered an excellent model for the study because of the many similarities between affected dogs and boys with Duchenne muscular dystrophy. It is known that the animal model GRMD have progressive muscle weakness, which leads to major changes in their gait. Knowlege of these adaptations in the absence of skeletal muscles can account for disease progression in this model as well as helping with a new tool for quantitative evaluation of future treatments for DMD. Porting this study addresses the variables of walking the dog GRDM in order to establish a tool for quantitative assessment of gait in this experimental model that may contribute to future therapeutic research and collaborate with the knowledge and applicability of animal gait biomechanics. We used six dystrophy animals selected from the colony of dogs GRMD - Brazil. Analysis was carried out of the body segments of biometrics, using kinematic and dynamic analysis of resulting from image and use of a force platform. The results obtained from the average of the biometrics body segments of the six animals studied: arm: $16,69 \mathrm{~cm}$; forearm 17,12cm; carpus 5,16cm; thigh $18,91 \mathrm{~cm}$; leg $19,03 \mathrm{~cm}$; tarsus $10,98 \mathrm{~cm}$; chest $67.54 \mathrm{~cm}$; height $52,14 \mathrm{~cm}$; e weight $20,44 \mathrm{~kg}$. In the kinematic analysis results obtained regarding the degree of flexion and extension of the following joints: escapuloumeral (flexion: $121.44^{\circ}$ and extension $152.76^{\circ}$ ), umeroradioulnar (flexion $121.68^{\circ}$ and extension $153.24^{\circ}$ ), carpo (flexion $122.2^{\circ}$ and extension $152.84^{\circ}$ ), coxofemoral (flexion $122.08^{\circ}$ and extension $153.96^{\circ}$ ), femortibiopatelar (flexion $121.2^{\circ}$ and extension $151.64^{\circ}$ ), tarsus (flexion $121.48^{\circ}$ and extension $153.44^{\circ}$ ). In dynamic analysis obtained from the force plataform the average values of peak groun reaction force of each animal were: Biz 141N, Gaspar 128N, Lola 180N, Luck 183N, Monstra 150N, Winner135N. Whith these results we conclude that the join femortibiopatelar was the one whith a degree of magnitude higher than in the other joints; peak flexion and extension vary according to each joint; peak flexion and extension vary more in the hind limb when comapred to the fore limb. The results obtained can be useful in pre-clinical evaluation using a canine model.
\end{abstract}

Key words: Biomechanics. Gait. Muscular dystrophy. 
LISTA DE ABREVIATURAS

CK creatina quinase

DMP distrofia muscular progressiva

DMP: distrofia muscular de Duchenne

DNA ácido desoxirribonucléico

GRMD: Golden Retriever Muscular Dystrophy

ISB Sociedade Internacional de Biomecânica

MDX X-linked muscular dystrophy mause 


\section{LISTAS DE FIGURAS}

Figura 1- Canil GRMD Brasil - Faculdade de Medicina Veterinária e Zootecnia da Universidade de São Paulo. Animais permanecem em pátio aberto durante o dia e em balas cobertas, de $3 \mathrm{~m}^{2}$ no período noturno

Figura 2 - Mensuração da morfometria dos animais estudados. Em A mensuração do braço, em B antebraço, em C carpo, em D perna, em E tórax e em $\mathrm{F}$ tarso .45

Figura 3 - Imagem coletada durante análise da marcha do animal II Gaspar .46

Figura 4 - Esquema representando os pontos anatômicos no hemicorpo esquerdo para coleta das imagens ......

Figura 5 - Ângulos articulares analisados 48

Figura 6 - Figura ilustrando a página inicial do Sistema Apas 49

Figura 7 - Figura ilustrando a página inicial do sistema MATLAB. .50 


\section{LISTA DE GRÁFICOS}

Gráfico 1 - Movimento da articulação escapuloumeral do animal I Biz, durante as fases de balanço, apoio e propulsão. A diminuição na curva representa uma diminuição do ângulo articular e o aumento da curva indica um aumento do ângulo articular.

Gráfico 2 - Movimento da articulação umeroradioulnar do animal I Biz, durante as fases de balanço, apoio e propulsão. A diminuição na curva representa uma diminuição do ângulo articular e o aumento da curva indica um aumento do ângulo articular.

Gráfico 3 - Movimento da articulação do carpo do animal I Biz, durante as fases de balanço, apoio e propulsão. A diminuição na curva representa uma diminuição do ângulo articular e o aumento da curva indica um aumento do ângulo articular.

Gráfico 4 - Movimento da articulação coxofemoral do animal I Biz, durante as fases de balanço, apoio e propulsão. A diminuição na curva representa uma diminuição do ângulo articular e o aumento da curva indica um aumento do ângulo articular.

Gráfico 5 - Movimento da articulação femortibiopatelar do animal I Biz, durante as fases de balanço, apoio e propulsão. A diminuição na curva representa uma diminuição do ângulo articular e o aumento da curva indica um aumento do ângulo articular

Gráfico 6 - Movimento da articulação do tarso do animal I Biz, durante as fases de balanço, apoio e propulsão. A diminuição na curva representa uma diminuição do ângulo articular e o aumento da curva indica um aumento do ângulo articular.

Gráfico 7 - Movimento da articulação escapuloumeral do animal II Gaspar, durante as fases de balanço, apoio e propulsão. A diminuição na curva representa 
uma diminuição do ângulo articular e o aumento da curva indica um aumento do ângulo articular

Gráfico 8 - Movimento da articulação umeroradioulnar do animal II Gaspar, durante as fases de balanço, apoio e propulsão. A diminuição na curva representa uma diminuição do ângulo articular e o aumento da curva indica um aumento do ângulo articular

Gráfico 9 - Movimento da articulação do carpo do animal II Gaspar, durante as fases de balanço, apoio e propulsão. A diminuição na curva representa uma diminuição do ângulo articular e o aumento da curva indica um aumento do ângulo articular.

Gráfico 10 - Movimento da articulação coxofemoral do animal II Gaspar, durante as fases de balanço, apoio e propulsão. A diminuição na curva representa uma diminuição do ângulo articular e o aumento da curva indica um aumento do ângulo articular

Gráfico 11 - Movimento da articulação femortibiopatelar do animal II Gaspar, durante as fases de balanço, apoio e propulsão. A diminuição na curva representa uma diminuição do ângulo articular e o aumento da curva indica um aumento do ângulo articular

Gráfico 12 - Movimento da articulação do tarso do animal II Gaspar, durante as fases de balanço, apoio e propulsão. A diminuição na curva representa uma diminuição do ângulo articular e o aumento da curva indica um aumento do ângulo articular.

Gráfico 13 - Movimento da articulação escapuloumeral do animal III Lola, durante as fases de balanço, apoio e propulsão. A diminuição na curva representa uma diminuição do ângulo articular e o aumento da curva indica um aumento do ângulo articular 
Gráfico 14 - Movimento da articulação umeroradioulnar do animal III Lola, durante as fases de balanço, apoio e propulsão. A diminuição na curva representa uma diminuição do ângulo articular e o aumento da curva indica um aumento do ângulo articular

Gráfico 15 - Movimento da articulação do carpo do animal III Lola, durante as fases de balanço, apoio e propulsão. A diminuição na curva representa uma diminuição do ângulo articular e o aumento da curva indica um aumento do ângulo articular.

Gráfico 16 - Movimento da articulação do coxofemoral do animal III Lola, durante as fases de balanço, apoio e propulsão. A diminuição na curva representa uma diminuição do ângulo articular e o aumento da curva indica um aumento do ângulo articular

Gráfico 17 - Movimento da articulação femortibiopatelar do animal III Lola, durante as fases de balanço, apoio e propulsão. A diminuição na curva representa uma diminuição do ângulo articular e o aumento da curva indica um aumento do ângulo articular

Gráfico 18 - Movimento da articulação do tarso do animal III Lola, durante as fases de balanço, apoio e propulsão. A diminuição na curva representa uma diminuição do ângulo articular e o aumento da curva indica um aumento do ângulo articular.

Gráfico 19 - Movimento da articulação escapuloumeral do animal IV Luck, durante as fases de balanço, apoio e propulsão. A diminuição na curva representa uma diminuição do ângulo articular e o aumento da curva indica um aumento do ângulo articular

Gráfico 20 - Movimento da articulação umeroradioulnar do animal IV Luck, durante as fases de balanço, apoio e propulsão. A diminuição na curva representa uma diminuição do ângulo articular e o aumento da curva indica um aumento do ângulo articular 
Gráfico 21 - Movimento da articulação do carpo do animal IV Luck, durante as fases de balanço, apoio e propulsão. A diminuição na curva representa uma diminuição do ângulo articular e o aumento da curva indica um aumento do ângulo articular.

Gráfico 22 - Movimento da articulação coxofemoral do animal IV Luck, durante as fases de balanço, apoio e propulsão. A diminuição na curva representa uma diminuição do ângulo articular e o aumento da curva indica um aumento do ângulo articular

Gráfico 23 - Movimento da articulação femortibiopatelar do animal IV Luck, durante as fases de balanço, apoio e propulsão. A diminuição na curva representa uma diminuição do ângulo articular e o aumento da curva indica um aumento do ângulo articular

Gráfico 24 - Movimento da articulação do tarso do animal IV Luck, durante as fases de balanço, apoio e propulsão. A diminuição na curva representa uma diminuição do ângulo articular e o aumento da curva indica um aumento do ângulo articular.

Gráfico 25 - Movimento da articulação escapuloumeral do animal V Monstra, durante as fases de balanço, apoio e propulsão. A diminuição na curva representa uma diminuição do ângulo articular e o aumento da curva indica um aumento do ângulo articular

Gráfico 26 - Movimento da articulação umeroradioulnar do animal V Monstra, durante as fases de balanço, apoio e propulsão. A diminuição na curva representa uma diminuição do ângulo articular e o aumento da curva indica um aumento do ângulo articular

Gráfico 27 - Movimento da articulação do carpo do animal V Monstra, durante as fases de balanço, apoio e propulsão. A diminuição na curva representa uma 
diminuição do ângulo articular e o aumento da curva indica um aumento do ângulo articular.

Gráfico 28 - Movimento da articulação coxofemoral do animal V Monstra, durante as fases de balanço, apoio e propulsão. A diminuição na curva representa uma diminuição do ângulo articular e o aumento da curva indica um aumento do ângulo articular

Gráfico 29 - Movimento da articulação coxofemoral do animal V Monstra, durante as fases de balanço, apoio e propulsão. A diminuição na curva representa uma diminuição do ângulo articular e o aumento da curva indica um aumento do ângulo articular

Gráfico 30 - Movimento da articulação do tarso do animal V Monstra, durante as fases de balanço, apoio e propulsão. A diminuição na curva representa uma diminuição do ângulo articular e o aumento da curva indica um aumento do ângulo articular.

Gráfico 31 - Movimento da articulação escapuloumeral do animal VI Winner, durante as fases de balanço, apoio e propulsão. A diminuição na curva representa uma diminuição do ângulo articular e o aumento da curva indica um aumento do ângulo articular

Gráfico 32 - Movimento da articulação cubital do animal VI Winner, durante as fases de balanço, apoio e propulsão. A diminuição na curva representa uma diminuição do ângulo articular e o aumento da curva indica um aumento do ângulo articular.

Gráfico 33 - Movimento da articulação do carpo do animal VI Winner, durante as fases de balanço, apoio e propulsão. A diminuição na curva representa uma diminuição do ângulo articular e o aumento da curva indica um aumento do ângulo articular. 
Gráfico 34 - Movimento da articulação coxofemoral do animal VI Winner, durante as fases de balanço, apoio e propulsão. A diminuição na curva representa uma diminuição do ângulo articular e o aumento da curva indica um aumento do ângulo articular

Gráfico 35 - Movimento da articulação femortibiopatelar do animal VI Winner, durante as fases de balanço, apoio e propulsão. A diminuição na curva representa uma diminuição do ângulo articular e o aumento da curva indica um aumento do ângulo articular

Gráfico 36 - Movimento da articulação do tarso do animal VI Winner, durante as fases de balanço, apoio e propulsão. A diminuição na curva representa uma diminuição do ângulo articular e o aumento da curva indica um aumento do ângulo articular.

Gráfico 37 - Pico de força de reação ao solo vertical do membro torácico dos seis animais estudados. 


\section{LISTA DE TABELAS}

Tabela 1- Animais selecionados do Canil GRMD Brasil para a pesquisa 43

Tabela 2 - Média dos valores dos dados morfométricos dos seis animais estudados. 52

Tabela 3 - Valores dos ângulos articulares dos seis animais estudados 77

Tabela 4- Média dos valores dos ângulos articulares dos seis cães estudados 78

Tabela 5- Média dos valores dos picos de força de reação ao solo de cada um dos animais... 79 


\section{SUMÁRIO}

1 INTRODUÇÂA

2 OBJETIVOS

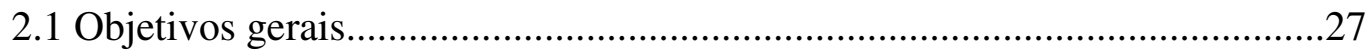

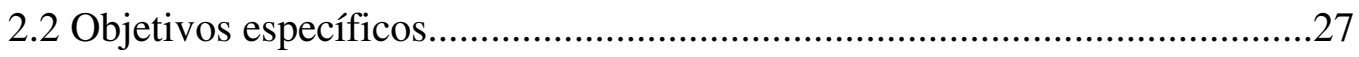

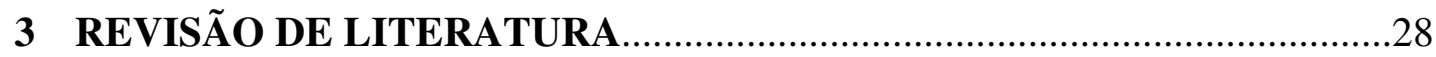

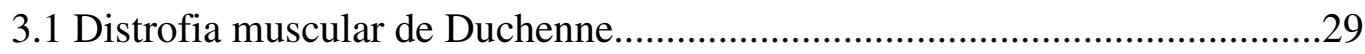

3.2 Distrofia muscular progressiva em cães....................................................32

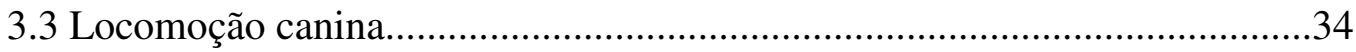

3.4 Avaliação biomecânica.......................................................................... 37

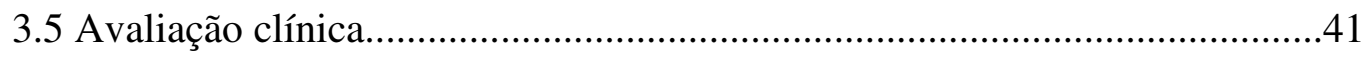

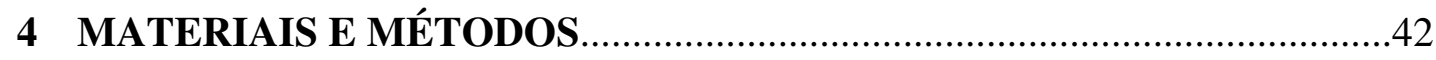

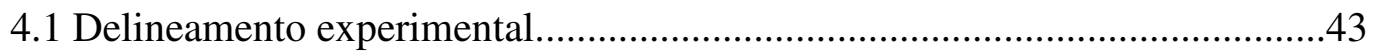

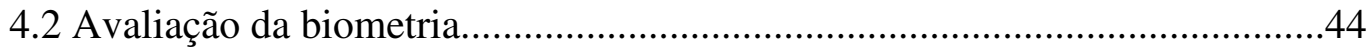

4.3 Avaliação biomecânica...........................................................................46

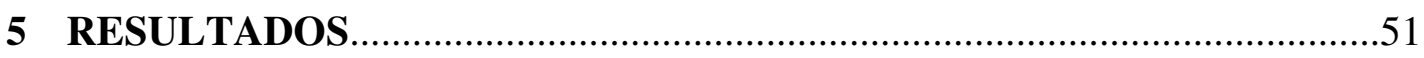

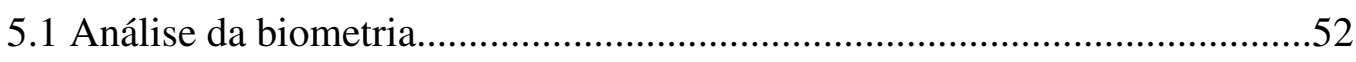

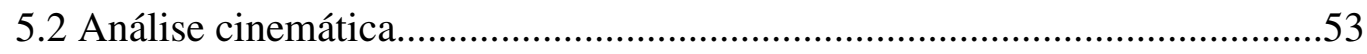

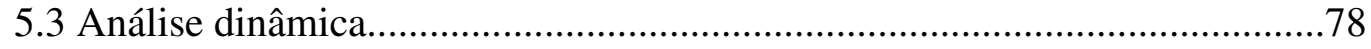

6 DISCUSSÃ

7 CONCLUSÃO

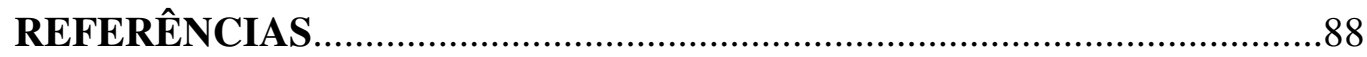




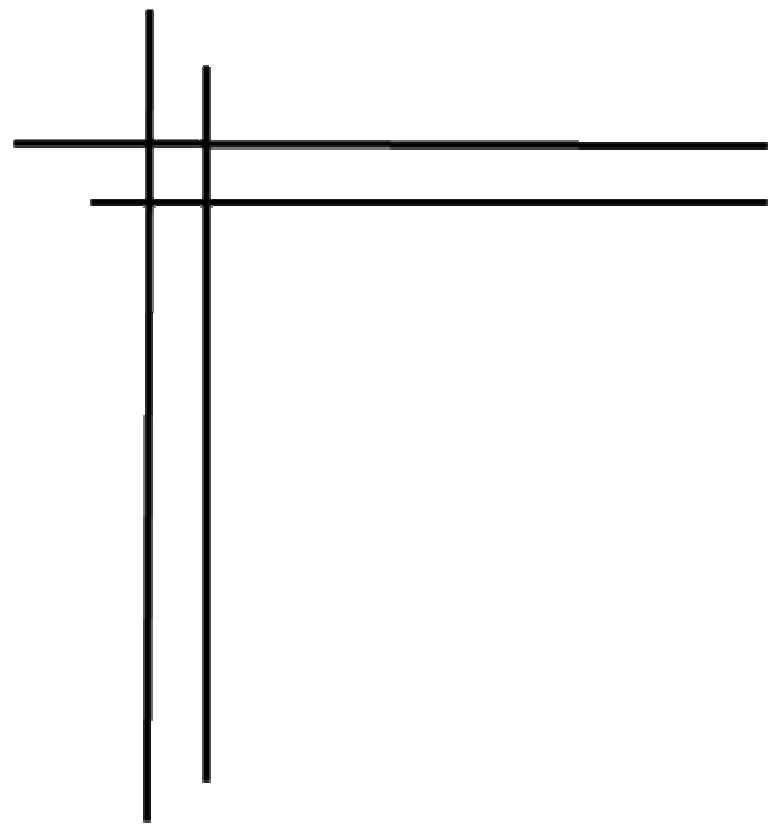

Introduçãa 


\section{INTRODUÇÃO}

A Distrofia Muscular Progressiva (DMP) em humanos engloba um grupo de doenças genéticas que se caracterizam por degeneração progressiva do tecido muscular (SCHATZBERG; SHELTON, 2004).A Distrofia Muscular de Duchenne (DMD)é a forma mais comum da doença, com uma incidência de aproximadamente um para cada 3500 nascimentos masculinos (COLLINS e MORGAN, 2004).

A DMD constitui um distúrbio genético de caráter recessivo e caracteriza-se pela deficiência ou ausência da proteína distrofina na superfície da membrana da célula muscular, podendo acometer a musculatura cardíaca e o sistema nervoso. Apresenta como sinais clínicos a perda progressiva da força muscular, resultando em fraqueza dos músculos respiratórios e cardíacos, sendo que a grande maioria dos pacientes desenvolve cardiomiopatia (CAROMANO, 1999).

Embora o camundongo $m d x$ seja o modelo animal mais utilizado em estudos de patogênese e dos efeitos da terapia gênica e transplante celular, um modelo canino da distrofia muscular de Duchenne com similar mutação pode ser superior ao camundongo, pois seu tamanho, sintomas e evolução clínica são mais próximos aos dos humanos (NICHOLS et al., 1994). No entanto há mais de dois modelos animais para DMD; além do modelo de camundongo mdx também podemos mencionar outros modelos de cães e também um modelo felino, embora ele não se assemelhe a DMD como o cão GRMD. (AMBRÓSIO et al., 2009).

O cão da raça Golden Retriever afetado pela distrofia muscular (GRMD), é considerado um excelente modelo para o estudo da eficácia da gene-terapia em miopatias por deficiência de distrofina, devido às muitas similaridades entre cães afetados e meninos com DMD (HOWELL et al., 1997).

Apesar do gene da distrofina ter sido descrito desde 1987 esta patologia progressiva e degenerativa permanece sem cura até os dias atuais. Dentre as principais terapias promissoras estão as terapias celular e gênica muito estudadas tanto no modelo mdx como no GRMD. Dentre as terapias atualmente disponíveis para a DMD estão as 
terapias de manutenção ou suporte da doença e entre elas destacam-se a corticoterapia, fisioterapia, terapia ocupacional, psicologia e nutrição. (STROBER, 2006).

Estudos sobre a intervenção fisioterapêutica no modelo GRMD são escassos. Entre os humanos, os métodos de fisioterapia renderam resultados controversos. Alguns desses métodos têm sugerido que pacientes com DMD devem realizar exercício físico moderado, enquanto outros têm sugerido que esses pacientes devem realizar atividades de recreação. No entanto, poucos estudos foram efetivamente avaliados como benéficos para a musculatura esquelética dos pacientes DMD. (MACHADO et al., 2009).

A biomecânica descreve, analisa e modela os sistemas biológicos, explica como a forma de movimento do corpo dos seres vivos acontece na natureza, a partir de parâmetros cinemáticos e dinâmicos (AMADIO, 1996). Embora a biomecânica seja relativamente jovem como um campo reconhecido da pesquisa cientifica, as considerações biomecânicas são valiosas em várias disciplinas cientificas e em campos profissionalmente diferentes. Os pesquisadores utilizam à mecânica, ramo da física que analisa forças e movimentos, para estudar os aspectos anatômicos e funcionais dos organismos vivos, possuindo conhecimentos acadêmicos prévios da zoologia, medicina ortopédica, cardíaca ou desportiva, fisioterapia ou cinesiologia, tendo em comum um grande interesse nos aspectos biomecânicos da estrutura e função dos elementos vivos (HALL, 2000).

Sabe-se que os animais do modelo GRMD apresentam fraqueza muscular progressiva, o que gera adaptações importantes na sua marcha. O conhecimento destas adaptações na ausência da musculatura esquelética pode esclarecer a evolução da doença neste modelo, bem como contribuir com uma nova ferramenta de avaliação quantitativa de futuros tratamentos da DMD.

Portando este estudo aborda as variáveis da marcha do cão GRMD buscando gerar novos conhecimentos sobre o efeito desta doença e colaborar para novas pesquisas nesse modelo com terapias celulares, medicamentos, fisioterapia e podendo assim avaliar pré e pós-tratamentos. 


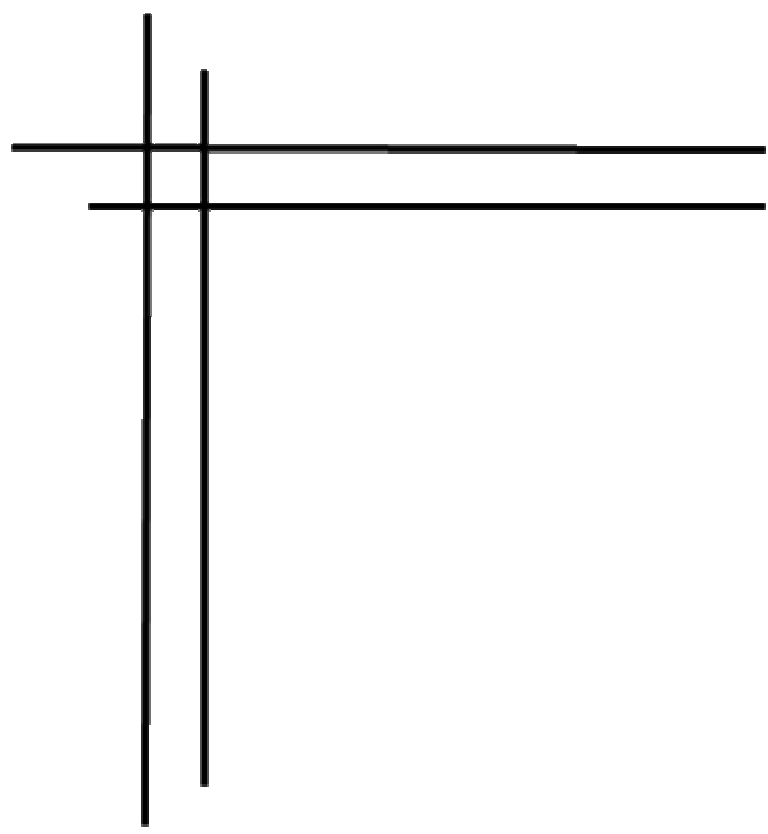

Objetivas 


\section{OBJETIVOS}

Os objetivos desse trabalho foram divididos em gerais e específicos

\subsection{OBJETIVOS GERAIS}

- Avaliar a locomoção de animais do modelo Golden Retriever Muscular Dystrophy (GRMD);

- Estabelecer uma ferramenta de avaliação quantitativa da marcha neste modelo experimental que possa contribuir para futuras pesquisas terapêuticas;

- Colaborar com o conhecimento e aplicabilidade da biomecânica na marcha animal.

\subsection{OBJETIVOS ESPECÍFICOS}

- Avaliar a morfometria dos animais do modelo GRMD.

- Avaliar as variáveis dinâmicas da marcha dos animais do modelo GRMD.

- Avaliar as variáveis cinemáticas da marcha dos animais do modelo GRMD. 


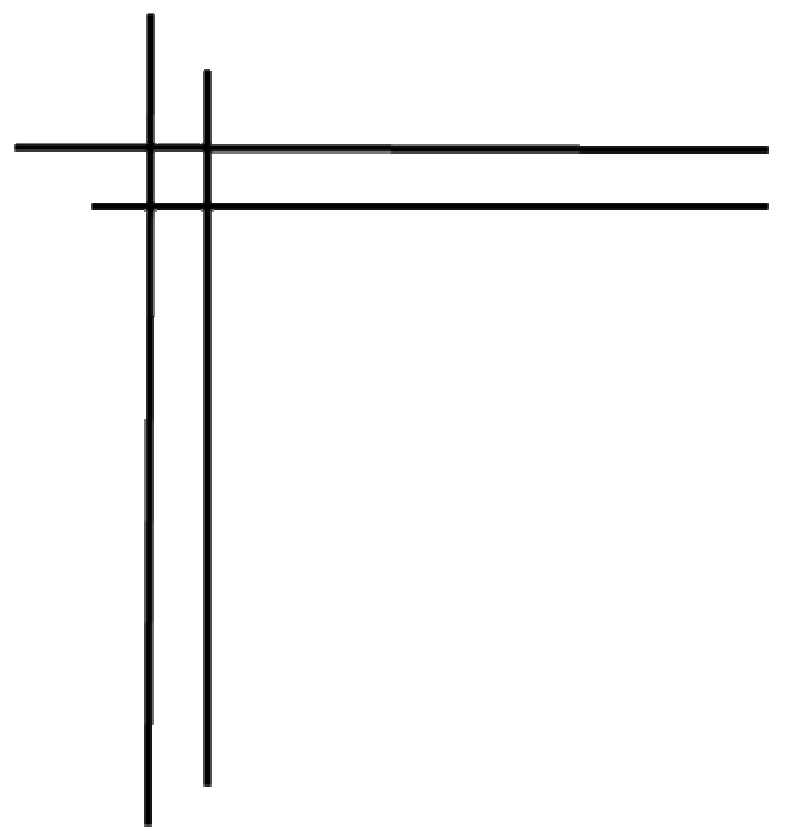

Revisãa de

Literatura 


\section{REVISÃO DE LITERATURA}

Alguns filósofos levam-nos hoje a olhar e compreender o movimento como algo resultante da constante interação entre homem e o meio envolvente, porém, compreender o movimento não é uma tarefa fácil (MEIJER, 2001; MATIAS; GAMBOA, 2005).

O movimento é resultado da interação dos sistemas biológicos e as suas propriedades mecânicas, fazendo com que seu estudo seja feito numa perspectiva neurofisiológica e biomecânica, ou seja, neuromecânica (ENOKA, 2000). Esses sistemas compostos por diversos elementos incluem o sistema fisiológico e anatômico, cada um com uma função relativa, única e necessária para a produção e regulação do mesmo (SAHRMANN, 2000).

\subsection{DISTROFIA MUSCULAR DE DUCHENNE}

Distrofia muscular é um termo amplamente utilizado para se referir a qualquer doença de ordem primária da musculatura esquelética, que resulta em degeneração progressiva, regeneração limitada e fibrose de miofibrilas. (BERGMAN et al., 2002). Existem pelo menos 30 formas diferentes, cuja herança pode ser autossômica dominante ou recessiva ligada ao cromossomo X (KEMPER; WAKE, 2007).

O quadro clínico é muito variável com formas graves de início na infância e progressão rápida e formas mais benignas com inicio na idade adulta e progressão mais lenta. Em 2/3 dos casos a mutação é adquirida da mãe e em 1/3 a mutação ocorre no próprio menino afetado (ZIMOWSKI et al., 2009).

Dentre as mais graves, e também mais comum das DMPs, está a distrofia muscular de Duchenne (DMD) que afeta meninos em uma proporção de 1 para cada 3500 nascidos homens. Teve seu primeiro gene identificado em 1986, e recebe esse 
nome em alusão a um neurologista francês que forneceu a primeira descrição da patologia completa em 1868 (JORDE, 2004).

Mutações no gene da distrofia levam a deficiência no gene da distrofina uma proteína associada ao sarcolema dos músculos lisos, cardíacos e esqueléticos que ajuda manter a integridade da membrana durante o processo de contração muscular. A DMD ocorre por um defeito localizado no braço curto do cromossomo $\mathrm{X}$ sendo portando, mais susceptível a mutações. Sendo assim a deficiência da distrofina afeta predominantemente as pessoas do sexo masculino, pelo fato das pessoas desse sexo possuir somente um cromossomo X (BERGMAN et al., 2002).

A distrofina participa juntamente com outras proteínas do complexo distrofina glicoproteínas (DGC), o qual possui funções mecânicas e estruturais, protegendo as fibras musculares de lesões produzidas por contração ao longo do tempo (Marques, 2004). Outros estudos sugerem seu desenvolvimento na permeabilidade na membrana de apoptose celular (HACK; GROH; MCNALLY, 2000).

Segundo Valentine et al. (1989), o músculo sem a proteína distrofina, fica mais susceptível a lesões induzidas pelo exercício, evidenciada pelo rápido influxo de enzimas musculares. Pelo fato desse processo protéico estar embebido no sarcolema e de fornecer a ligação entre o citoesqueleto interno da célula muscular a matrix extracelular, a perda destrói essa ligação e então gera a degeneração muscular, podendo acometer a musculatura cardíaca e o sistema nervoso.

Os primeiros sintomas desenvolvem-se por volta dos três a cinco anos, com manifestação de dificuldades dos membros inferiores: quedas freqüentes, dificuldade para subir escadas, correr, levantar do chão e as crianças apresentam aumento do volume das panturrilhas. Alterações da coluna e dos tendões são conseqüências das alterações musculares dos membros posteriores. Com o progredir da doença ocorre comprometimento dos músculos dos membros superiores. A fraqueza progressiva evolui pra incapacidade de andar, em geral ao redor da adolescência. $\mathrm{O}$ comprometimento do músculo cardíaco e dos músculos respiratórios ocorre a partir desta idade (KEMPER; WAKE, 2007).

Na maioria dos casos de DMD, o diagnóstico pode ser estabelecido através da história familiar, de achados clínicos, laboratoriais e genéticos (análise de DNA), 
podendo ser utilizados eventualmente, exames eletrofisiológicos e histológicos. Os níveis enzimáticos, principalmente de creatina quinase (CK), biopsia muscular e análise de DNA são amplamente explorados na caracterização da doença (CAROMANO, 1999).

A dosagem de CK é de extrema importância uma vez que servirá de indicação no diagnostico diferencial entre as forma de distrofias musculares progressiva. Na DMD, os autores colocam que os níveis de CK estão aumentados de 100 a 300 vezes na fase pré-clinica. Através de Westem blot também se pode diagnosticar a DMD ao detectar menos de $3 \%$ de distrofina no músculo, associada à diminuição de $\alpha$ sarcolicanas (ERAZO-TORRICELLI, 2004).

O estudo imuno-histoquimico permite detectar a presença ou ausência de proteínas do sarcolema ou ligadas a esta membrana, incluindo a determinação da porcentagem de núcleos centralizados e a variabilidade do tamanho das fibras. Ambos os parâmetros juntos descrevem bem o processo de degeneração da musculatura esquelética (BRIGUET, 2004; ERAZO-TORRICELLI, 2004).

$\mathrm{Na}$ analise da estrutura do músculo esquelético a partir da biopsia, realizada normalmente nos músculos quadríceps, gastrocnêmio ou deltóide, observa-se padrão distrófico, ou seja, perda da forma poligonal em corte transversal, necrose e regeneração de fibras com deposição em tecido conjuntivo e adiposo. Em algumas distrofias, tais como as congênitas, o padrão distrófico da fibra muscular não se apresenta em idades precoces. Desta forma, a ausência de alterações distróficas características, nem sempre descarta a existência de uma distrofia muscular (ERAZO - TORRICELLI, 2004).

Em estudo feito com trinta pacientes portadores de DMD Wang et al. (1999), notaram alterações histopatológicas em todos os casos estudados, tais como degeneração, necrose e regeneração das fibras musculares. Em relação às reações imuno-histoquímicas, todos os sujeitos mostraram reações negativas para anticorpos anti-distrofina Dys 1-3. Em três dos trinta casos estudados, com quadro clínico severo, foram observadas algumas características diferentes na morfometria, como ausência de diferença no diâmetro das fibras do tipo I e II, e o diâmetro das fibras do tipo I em um dos casos foi menor do que todos os outros trinta, com grande proliferação de tecido conjuntivo e adiposo. 


\subsection{DISTROFIA MUSCULAR PROGRESSIVA EM CÃES}

Modelos animais são usados para fornecer hipóteses cientificas na DMD. Dentre eles, os mais estudados são o camundongo $m d x$ e o canino Golden Retriever Muscular Dystrophy (GRMD).

O camundongo $m d x$ mantém relativamente seu quadro clínico devido à patologia ser considerada moderada e a função mecânica muscular pouco comprometida, além de não apresentar fibrose endomisial extensiva, uma das características patológicas mais importantes na DMD (YAMAZAKI et al.,1994; COLLINS; MORGAN, 2003).

Mutações espontâneas do gene da distrofina, resultando na distrofia muscular ligada ao cromossomo X têm sido identificadas em diversas raças de cães domésticos: $\mathrm{o}$ Golden Retriever, o Rottweiller e o Beagle. Destes, o GRMD tem sido o modelo mais amplamente estudado e melhor caracterizado. Em 1958, Méier documentou o primeiro caso de cão com distrofia em um filhote de Golden Retriever. Desde as primeiras descrições, a mutação do gene da distrofina no GRMD tem sido identificada e então, este modelo animal tem sido reconhecido e amplamente utilizado nas avaliações experimentais de novos tratamentos previamente aos estudos clínicos em humanos (COLLINS; MORGAN, 2003; SHELTON, 1994).

A distrofia muscular canina ligada ao cromossomo $\mathrm{X}$ em cães do modelo GRMD tem similaridades fenotípicas e genotípicas com a Distrofia Muscular de Duchenne (DMD) em humanos (SHELTON, 1994; NGUYEN et al., 2002) o que torna o cão GRMD é um útil modelo pré-clínico, porque imita a doença humana em muitos aspectos mais perto do que outros modelos existentes de mamíferos de deficiência de distrofina. Como pacientes com DMD, os cães GRMD sofrem com a da falta distrofina. Seus músculos esqueléticos são submetidos a um processo degenerativo, levando à fibrose progressiva. Locomoção prejudicada é uma característica precoce desta doença. Geralmente também provoca insuficiência respiratória, disfagia e cardiomiopatia. Secundariamente, anquilose, pneumonias, megaesôfago e hérnia hiatal (AMBRÓSIO et. al., 2009). 
Por essas características o GRMD é considerado o modelo animal mais relevante para o estudo da DMD, embora o uso deste animal para pesquisa requer um alto custo, além de possuir uma variação intra-animal a qual dificulta uma padronização (COLLINS; MORGAN, 2003; MCCLOREY et al., 2006).

O cruzamento de cães GRMD de uma fêmea heterozigota, ou seja, portadora do gene com a distrofia, com um macho afetado gera machos normais, fêmeas heterozigotas e machos e fêmeas afetados (NGUYEN, 2000).

Logo no primeiro dia de vida, os cães afetados já são diagnosticados através da $\mathrm{CK}$, que se encontra acentuadamente elevada na maioria dos casos, e juntamente por teste genético utilizando reação em cadeia de polimerase (PCR) (VALENTINE et al., 1990).

O curso da doença é paralela à doença humana e, em conjunto com o grande tamanho deste modelo animal faz cães GRMD útil para a avaliação das abordagens terapêuticas com a intenção de combater a DMD (BARTHÉLÉMY et al., 2009). Embora muitos filhotes possam morrer durante o período neonatal, dentre os sobreviventes, ao redor dos dois meses de idade, podem ser constatados sinais de regeneração muscular verificável pela imaturidade do tecido muscular através de imunohistoquímica. Os sinais clínicos progridem rapidamente entre os 3 e 6 meses de idade. Quando ultrapassam este período crítico, apresentam expectativa de vida de três a cinco anos. A causa da morte quando adultos é a cardiomiopatia. O músculo cardíaco é afetado tanto em humanos como em cães, porém, os meninos portadores de DMD morrem devido à atrofia dos músculos que levam a problemas respiratórios antes que eles progridam para o estágio de cardiomiopatia (NGUYEN et al., 2002).

As lesões musculares se caracterizam por necrose maciça, que afeta principalmente músculos da cabeça, pescoço e membros. Clinicamente, os cães afetados cansam-se com facilidade, desenvolvem deformidades esqueléticas e marchas altamente anormais, caracterizadas por passadas rígidas e curtas. Pode ainda apresentar redução na capacidade de abrir os maxilares e dificuldade na apreensão e deglutição de grupos musculares e a língua apresentam-se com hipertrofia. Esta hipertrofia está associada com a disfunção da faringe e do esôfago resultando em disfagia, sialorréia e regurgitação (NGUYEN ET al., 2002). De acordo com Valentine et al. (1990), as lesões 
no músculo da língua podem se iniciar ainda na vida intra-uterina. A função respiratória esta diminuída e caracterizada pelo aumento da frequiência respiratória de repouso e um excessivo componente abdominal respiratório após mínimos esforços (NGUYEN et al., 2002).

Outra diferença é que os cães podem continuar a se movimentar com seus problemas musculares precoces uma vez que são quadrúpedes, mas os meninos afetados perdem sua habilidade para ficar eretos e precisam utilizar-se de cadeiras de rodas (NGUYEN et al., 2002).

Adicionalmente, outros sistemas de órgãos musculares e não musculares também podem estar alterados em humanos e animais distróficos. Estudos realizados discorreram sobre aumentos de tensão ocasionada pela ausência do gene da distrofina em camundongos $m d x$. Além disso, relataram síndrome de má absorção e processos diarréicos atribuídos à disfunção pancreática em humanos (BAROHN, 1988; MIYATAKE et al., 1989; MORIUCHI et al., 1991; GRANDO et al., 2009).

As semelhanças clínicas na evolução e gravidade da distrofia entre humanos com DMD e o modelo GRMD, justificam seu uso como modelo de estudo para os mecanismos que contribuem para a lesão em músculos distróficos e, mais importante ainda, para os fatores que lidam com a regeneração (CHILDERS et al., 2001).

\subsection{LOCOMOÇÃO CANINA}

A locomoção é o processo pelo qual o animal se move de uma posição geográfica para outra. Ela inclui início, parada, mudanças na velocidade, alterações na direção e adaptações para as mudanças da inclinação do terreno. Os animais apresentam um deslocamento rítmico das partes do corpo, que mantém em progresso constante para frente (GILLETTE; ANGLE, 2008).

Ao andar lentamente os animais tendem a coordenar os quatro membros de modo que três membros fiquem apoiados como lactente que engatinha e avança um membro apenas quando os outros três estão apoiados no solo (DECAMP, 1997). 
Zoólogos concluíram que a maioria dos vertebrados incluindo o homem escolhem um marcha que otimiza a economia ou consumo de energia metabólica para determinada velocidade (HALL, 2000), ou seja, a marcha normal é o movimento para frente com eficiência, uma vez que há um mínimo gasto de energia durante esta atividade.

$\mathrm{Na}$ análise de locomoção deve-se atentar a fatores que implicam de forma relevante á qualidade do movimento como a região dorsal e a região lombar que têm importante participação no alinhamento postural. Tanto o comprimento do dorso quanto da região lombar devem ser enquadrados no padrão da raça objetivando o tipo de movimentação característica favorecendo um melhor desempenho muscular otimizando as funções específicas de cada raça (BOMBONATO et al., 2005).

A avaliação subjetiva da marcha canina tem sido utilizada por muitos anos. Contudo, a nossa capacidade de perceber detalhes minuciosos durante o ciclo da marcha pode ser difícil e em alguns aspectos, até mesmo impossível para o especialista da marcha mais talentoso. A evolução da informática na análise da marcha assistida por computador nos últimos 20 anos tem vindo a melhorar a capacidade de definir quantitativamente as características da marcha. Estes avanços tecnológicos e os novos desenvolvimentos nas abordagens metodológicas têm ajudado pesquisadores e clínicos em ganhar uma melhor compreensão de locomoção canina. A utilização de análise cinemática e cinética tem sido validada como um instrumento útil na medicina veterinária (GILLETTE; ANGLE, 2008).

A marcha canina pode ser dividida em dois grupos: simétrica e assimétrica. $\mathrm{Na}$ primeira observa-se que o trote e o passo dos membros de um lado do corpo são repetidos do outro lado do corpo. Já na segunda observa-se uma rotação no galope e os movimentos do membro de um lado do corpo não se repetem do lado oposto, incluindo outros sinais clínicos (DECAMP, 1997).

Para cada tipo de locomoção detalhes adicionais do movimento das patas e membros podem ser descritos. A fase de apoio é definida como período na qual a pata toca e permanece no solo. A fase de balanço é definida como período na qual a pata permanece no ar. Juntas, as fases de apoio e balanço de um membro são consideradas um passo. A fase de apoio ainda pode ser dividida em apoio inicial, desaceleração, 
propulsão e apoio final. O ciclo da locomoção de quadrúpede pode ser definido como uma série de eventos que inclui um passo para cada um dos quatro membros, independentemente do tipo de locomoção (DECAMP, 1997)

A marcha normal ou simétrica pode ser dividida em dois tipos: lateral ou diagonal (BOMBONATO et al., 2005). Os ciclos da marcha humana são definidos por dois períodos que são a fase de apoio e a fase de balanço. Estes períodos são separados por dois eventos: o instante em que o pé faz o contato como o solo e o instante em que o pé deixa o solo. Um ciclo completo compreende a retirada ou colocação do pé até a sua retirada ou colocação novamente no solo, ou seja, uma passada (ENOKA, 2000).

A caminhada inclui dois ou três membros na fase de estação. $\mathrm{O}$ trote coloca geralmente dois membros em contato com o solo. Durante as fases da marcha, o cão realiza movimentos que determinam as subfases. No apoio inicial o membro inicia seu contato como o solo, quando o membro já está totalmente apoiado ele recebe a carga, inicia transferência de peso para os outros membros para iniciar a fase de propulsão, realiza o balanço e inicia uma extensão do membro para a acomodação ou desaceleração, uma preparação para um novo apoio e o início de um novo ciclo (DECAMP, 1997).

Existem vários métodos de análise da locomoção, o método mais simples é a análise visual durante a locomoção (HARRIS; WERTSCH, 1994). Esta observação clínica e visual, no entanto, é subjetiva e os pesquisadores têm desenvolvido métodos mais objetivos para avaliar o andar quantitativamente (ANDERSON; MANN, 1993).

O laboratório moderno de locomoção compreende três elementos interdependentes para avaliar a função locomotora: capacidade de percepção humana, medidas quantitativas e análise biomecânica. A cinesiologia é ciência do movimento e pode ser dividida em áreas: cinética e cinemática. Cinemática é a descrição do movimento, independente das influências da massa e da força. Cinética é o estudo das relações do movimento e das forças geradoras do movimento (DECAMP, 1997).

A análise clínica é feita através da observação visual, que é útil, porém limitada, pois é mais descritiva do que quantitativa. Enquanto a análise quantitativa vai a um estágio mais evoluído da avaliação, medindo os passos sincronizadamente, calculando variáveis angulares (CLAYTON, 1991; HARRRIS, 1994). 
De acordo com Guo (2002), a análise laboratorial da marcha é de fácil uso e pode fornecer resultado visual, o que leva a uma rápida compreensão. Uma das vantagens da análise de marcha canina em laboratórios e a avaliação da angulação articular ativa, onde analisamos o movimento realizado por um indivíduo sem qualquer auxílio.

De acordo com Marques (2003) quando a amplitude é realizada ativamente, o examinador tem a informação exata sobre a capacidade e coordenação da amplitude de movimento articular. Ao avaliar a amplitude de movimento ativa e o indivíduo ao completar o movimento sem esforço e sem dor tem-se a noção exata da real condição da angulação articular. Isto não é possível na análise feita com o uso de goniômetros, onde o animal encontra-se sedado e o movimento é analisado passivamente.

\subsection{AVALIAÇÃO BIOMECÂNICA}

A biomecânica é uma disciplina que, entre as ciências derivadas das ciências naturais se preocupa com as análises físicas de sistemas biológicos, conseqüentemente, de análises físicas dos movimentos, suas causas e fenômenos (AMADIO, 1999).

O método utilizado pela biomecânica consiste na observação, teorização, experimentação, validação e aplicação. Em 1979, a comunidade internacional adotou o termo biomecânica para a ciência que estuda os sistemas biológicos de uma perspectiva mecânica, estuda os aspectos anatômicos e funcionais dos organismos vivos, os fenômenos e as causas dos movimentos, normal ou patológico (HALL, 2000).

Os animais estão expostos as mesmas forças físicas que os objetos inanimados, logo a subdivisão da biomecânica é análoga a da mecânica física em duas disciplinas: biodinâmica e bioestática. A primeira é o estudo do movimento em que há aceleração. A biodinâmica se divide em cinética e cinemática. Já o segundo é o estudo dos sistemas que se encontram em repouso ou em estado de movimento constante (HALL, 2000).

Cinemática é uma técnica baseada na análise de eventos definidos pela trajetória de um ponto que tenha uma posição anatômica fixa no corpo durante a marcha 
(STANHONE, 1990). Ela busca medir parâmetros do movimento como posição, orientação, velocidade e aceleração através de imagens registradas do movimento, e através de um software específico, onde essas variáveis são calculadas (AMADIO, 1999).

Embora a análise cinemática propicie uma medida direta de posição em relação ao tempo e seja um bom indicador dos padrões de movimento durante a fase de apoio e de balanço da ação do membro (quando ocorre a maior parte do movimento), ela é menos sensível quando o membro contatar o solo e com qual carga de peso ele o faz. Para muitas patologias a questão principal é exatamente a carga de peso com a qual o membro contacta o solo. Dessa forma, a análise cinemática é freqüentemente ineficaz para perceber as diferenças importantes na função do membro (BERTRAN et al., 1997).

Ela tem sido utilizada com o objetivo de caracterizar o movimento articular nas mais variadas espécies e para caracterizar a amplitude de movimento em cães saudáveis e com afecções ortopédicas, através de análise das variáveis espaciais e temporais do indivíduo, descreve o movimento incluindo o padrão e velocidade das sequiências de movimentos realizados pelos segmentos corporais que freqüentemente correspondem ao grau de coordenação motora demonstrada pelo indivíduo (WINGFIELD, 1993; HALL, 2000; MARSOLAIS et al., 2003).

Medidas cinemáticas tridimensional da marcha são rotineiramente utilizadas na análise clínica da marcha e dar um desfecho chave para a investigação da marcha e prática clínica (MARSOLAIS et al., 2003).

Para análises bidimensionais ou tridimensionais do movimento a sociedade internacional de biomecânica (International Society Biomechanics - ISB) sugeriu normalizações para o sistema de referência de medidas biomecânicas como:

- Eixo X horizontal na direção do movimento;

- Eixo Y vertical paralelo a direção da força da gravidade;

- Eixo $\mathrm{Z}$ horizontal na direção perpendicular a direção do movimento. (AMANDIO, 1996). 
As variáveis cinemáticas estão envolvidas na descrição do movimento independente das forças que o causam. Ela inclui deslocamento linear e angular, velocidade a aceleração. Os dados de deslocamento são referentes a marcas anatômicas como: centro de gravidade dos segmentos corporais, centro de rotação articular, extremidades dos membros ou proeminências corporais anatômicas (WINTER, 1990).

As análises cinemáticas são normalmente baseadas em um conjunto de dados de posição x tempo obtido com auxílio de câmaras de vídeo, resultado em um conjunto de imagens fixas (quadros) que são projetadas individualmente sobre um equipamento de medida, e a localização dos pontos pré-determinados pode ser efetuada. O digitalizador determina as coordenadas (x, y) desses pontos de referência (AMANDIO et al. 1999; ENOKA, 2000).

As coordenadas $\mathrm{x}, \mathrm{y}$ e $\mathrm{z}$ definem o espaço tridimensional. $\mathrm{O}$ par dessas cooredenadas define planos bi-dimensionais. Em termos anatômicos estes três planos são definidos como transversal (x), sagital (z) e frontal (y) (ENOKA, 2000).

A cinemática da locomoção normal e anormal pode ser estudada através do uso de plataformas de força. Estas avaliam as forças de reação ao solo geradas durante a locomoção e, embora sejam uma das muitas formas pelas quais a locomoção pode ser estudada, elas vem sendo utilizadas com maior frequiência e estão preenchendo uma lacuna importante no entendimento da biomecânica do andar (ANDERSON et al.,1988; BESANCON et al., 2003).

A força de reação do solo (FRS) é a força externa que age sobre o corpo durante a fase de contato com o solo e é interpretada de acordo com as leis de movimento Newtoniana. Para medir variáveis á FRS é utilizada principalmente plataformas de força, que permitem a mensuração da força de reação produzida durante a fase de contato do movimento. (PICON, 2004).

Ao executar suas funções de sustentação e movimentação do corpo, os ossos dos membros torácicos (anteriores) e pélvicos (posteriores) dos animais quadrúpedes sofrem a ação de um complexo conjunto de forças. Em uma condição estática, esses ossos resistem à ação da gravidade, suportando o peso do corpo como também a força muscular necessária para manter a postura. Em uma situação dinâmica, o corpo do 
animal é alternadamente sustentado por dois ou três membros que suportam todo o peso do corpo (ENOKA, 2000).

Budsberg, Verstraete e Soutras-Litte (1987) redefiniram a metodologia da análise da locomoção no cão pelo uso da placa de força, introduzindo uma nova era de análise objetiva do andar na medicina veterinária.

As placas e plataformas de força têm sido utilizadas na avaliação das forças de reação ao solo em cães ao passo, trote, galope e durante o salto. (BUDBERG et al., 1987; RUMPH et al., 1994; ALLEN et al., 1994; BERTRAN et al., 1997; FANCHON et al., 2006; WALTER et al., 2007).

A placa de força mensura as forças ortogonais de reação ao solo resultante da locomoção em três planos (BUDSBERG et al., 1987). Estas forças representam a somatória das forças do tronco e membro trasmitidas através de um membro ao solo. São eles: (a) médio lateral (Fx); (b) crânio caudal (Fy), conhecida como força aceleradora ou desaceleradora; e (c) Força vertical (Fz).

Geralmente a força de pico (máxima) nos eixo vertical e crânio caudal são avaliados como medidas objetivas da função do membro. A força vertical e crânio caudal também podem ser integrados sobre o tempo, descritas como impulso vertical e crânio caudal, como uma medida da função através da fase de apoio (BUDSBERG et al., 1987). Estas três forças têm diferentes importâncias durante a análise da locomoção.

A força pico vertical e o impulso vertical são as mais utilizadas pelos pesquisadores para avaliar a locomoção normal e patológica (BUDSBERG et al., 1987; RUMPH et al., 1994). A força vertical mede de forma mais direta a sustentação do peso e tem maior magnitude quando comparada com outras forças ortogonais e, na presença de claudicação esta se encontra reduzida em relação ao normal (DECAMP, 1997). A força crânio caudal é mensurada para quantificar a força do membro que atua para a progressão da locomoção do animal. A fase de apoio subdivide-se em (a) desaceleração e (b) aceleração ou propulsão, de acordo com o sinal negativo ou positivo da em força em questão. 


\subsection{AVALIAÇÃO CLÍNICA}

Estudos com terapias celulares, medicamentosa e fisioterapêutica têm sido estudados no modelo GRMD, devido às similaridades dos meninos portadores de DMD e cães adultos, que apresentam quantidade de tecido muscular equivalente, o que possibilita o monitoramento da fraqueza muscular.

Em experimentações com terapia gênica no modelo mdx, mostraram redução na degeneração das miofibrilas e aumento da resistência muscular, sem aumentar a massa e a força muscular dos animais. Nesse mesmo estudo Abmaya et al., 2005, fizeram injeção com outro vetor (rAAV/mlgf1) que aumentaram a massa muscular, mas não foram capazes de proteger a fibra muscular do processo de degeneração.

Em estudo com células tronco, procurou levar ao músculo distrófico células musculares normais, com objetivo de que estas novas células se fundam com as distróficas melhorando as alterações patológicas e a função muscular. Chakkalakal et al., 2005

Em outro estudo com células tronco isolou-se células CD133 coletadas em cães GRMD e fizeram duas injeções das mesma na artéria femoral esquerda desses cães. Observaram que todos os cães tratados tiveram uma melhora do desempenho clínico e melhora morfológica nos músculos analisadas quando comparados ao grupo controle (MEREGALLI et al., 2011)

Neste contexto a avaliação biomecânica da marcha desses animais poderá contribuir para avaliações pré-clinica com a utilização de terapia celular entre outras para verificar a eficácia ou não dessas técnicas. 


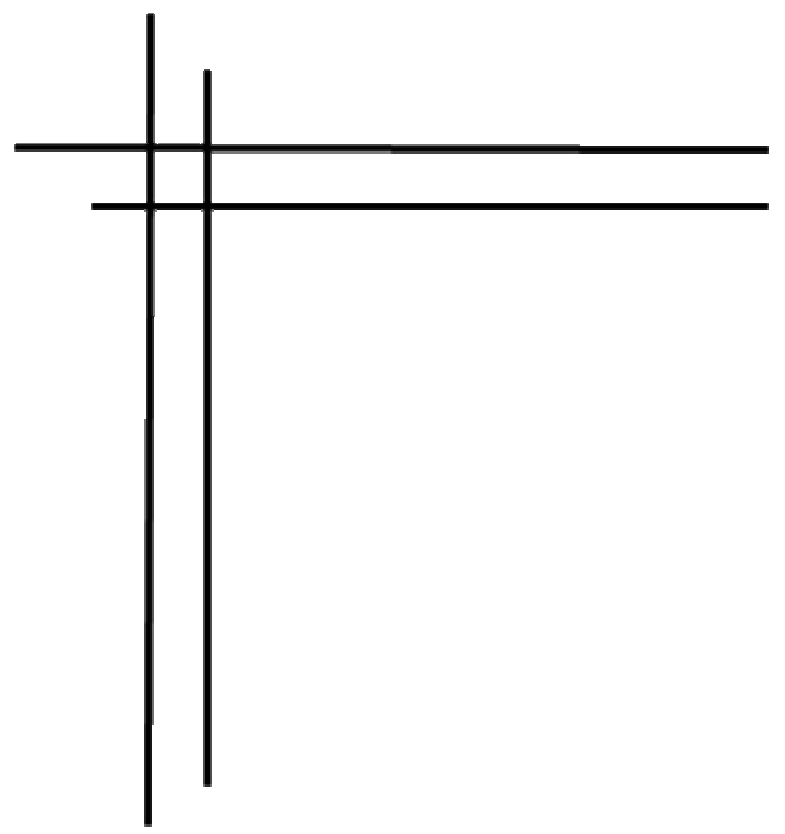

Materiais e Métadas 


\section{MATERIAIS E MÉTODOS}

Os animais estudados foram selecionados da colônia de cães GRMD - Brasil, localizado na Faculdade de Medicina Veterinária e Zootecnia da Universidade de São Paulo, Departamento de Cirurgia - Setor Anatomia. Na data da realização dessa pesquisa, o canil possuía nove animais afetados pela distrofia muscular homóloga a distrofia muscular de Duchenne encontrados em humanos além de oito fêmeas portadoras destinadas a reprodução.

Esse projeto foi aprovado pela comissão de Bioética da Faculdade de Medicina Veterinária e Zootecnia da Universidade de São Paulo (protocolo 1920/2010).

\subsection{DELINEAMENTO EXPERIMENTAL}

Seis animais distróficos foram aceitos para participar do projeto uma vez que cumpriam os critérios de inclusão estabelecidos: apresentar parâmetros clínicos estáveis durante o experimento e o ciclo da marcha desses animais incluírem apoio dos quatro membros. A tabela 1 mostra os animais selecionados para essa pesquisa. Os números indicam a identificação feita por microchip.

Tabela 1- Animais selecionados do Canil GRMD Brasil para a pesquisa

\begin{tabular}{lll}
\hline Animal & Idade/data da coleta & Peso/ data da coleta \\
\hline Animal I & 54 meses & $22,800 \mathrm{~kg}$ \\
Animal II & 39 meses & $15,900 \mathrm{~kg}$ \\
Animal III & 39 meses & $24,300 \mathrm{~kg}$ \\
Animal IV & 54 meses & $26,500 \mathrm{~kg}$ \\
Animal V & 57 meses & $28,200 \mathrm{~kg}$ \\
Animal VI & 72 meses & $21,300 \mathrm{~kg}$ \\
\hline
\end{tabular}


A rotina dos animais distróficos do Canil GRMD - Brasil inclui permanência no pátio ao ar livre onde são realizadas as atividades de vida diária como alimentação, ingestão de água e ambulatório para avaliação clínica regular, com restrição noturna em baia coberta de $3 \mathrm{~m}^{2}$. (Figura 1 )

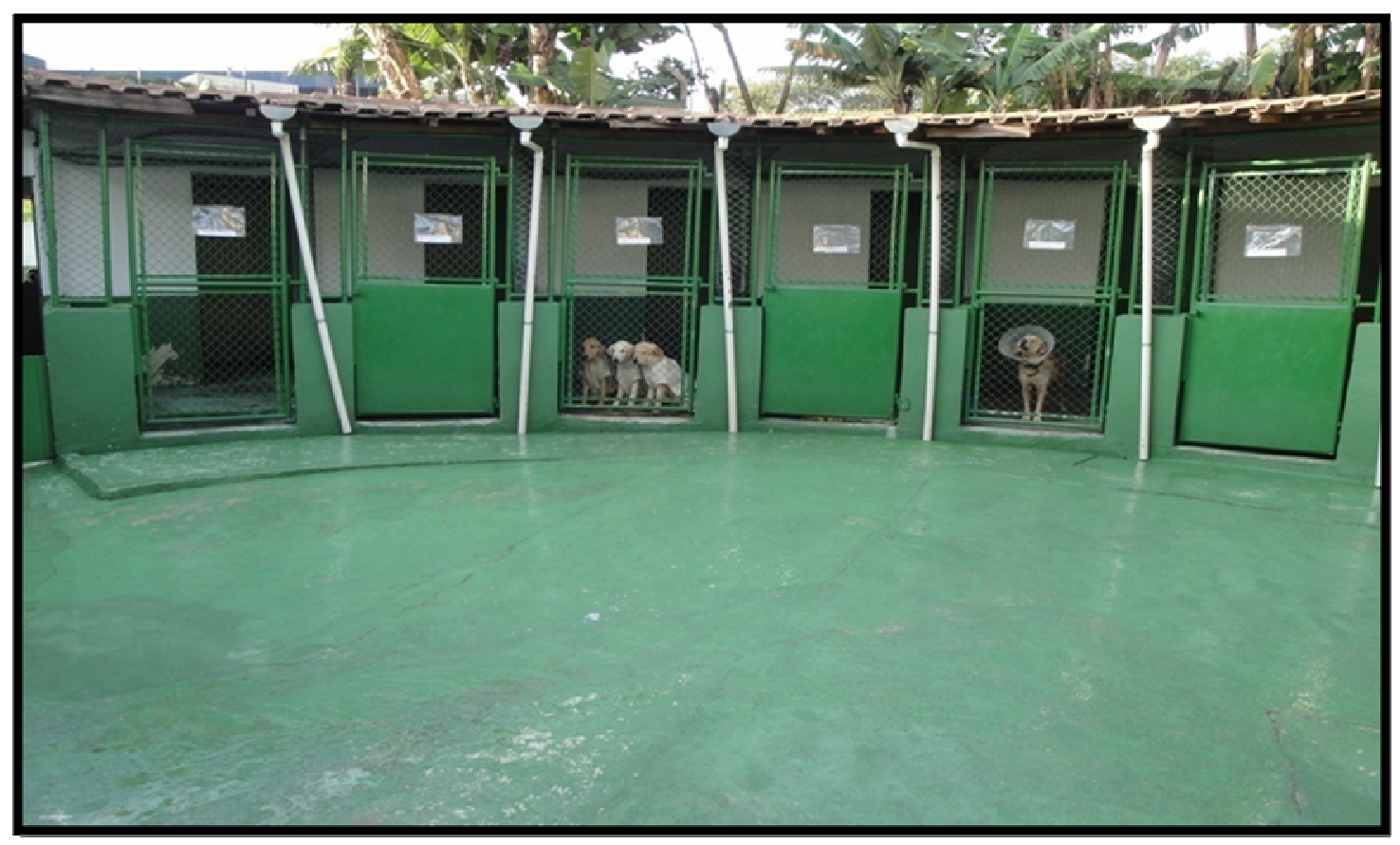

Figura 1 - Canil GRMD Brasil - Faculdade de Medicina Veterinária e Zootecnia da Universidade de São Paulo. Animais permanecem em pátio aberto durante o dia e em balas cobertas, de $3 \mathrm{~m}^{2}$ no período noturno.

\subsection{ANALISE DA BIOMETRIA}

Para análise da biometria, foi considerado o comprimento dos segmentos corporais, a circunferência do tórax e altura de cada animal para verificar possíveis variações nos cães estudados.

Os animais foram avaliados individualmente em estação. Com a utilização da fita métrica foram mensurados o comprimento dos segmentos de braço, antebraço, coxa, 
perna e tórax. A altura de cada animal foi medida da espinha da escápula até o quinto metacarpo.

Os segmentos corporais de referencia foram: úmero (tubérculo maior do úmero/epicôndilo lateral do úmero), ulna (epicôndilo lateral do úmero/processo estilóide da ulna), carpo (processo estilóide da ulna/cabeça do quinto metacarpo), fêmur (trocânter maior do fêmur/côndilo femoral), tíbia (côndilo femoral/maléolo lateral), tarso (maléolo lateral/cabeça do quinto metatarso) e tórax (processo xifóide).

Cada segmento foi mensurado três vezes para minimizar possíveis erros de medida, sendo utilizada para análise a média das três medidas. A figura 2 ilustra a mensuração dessas medidas.

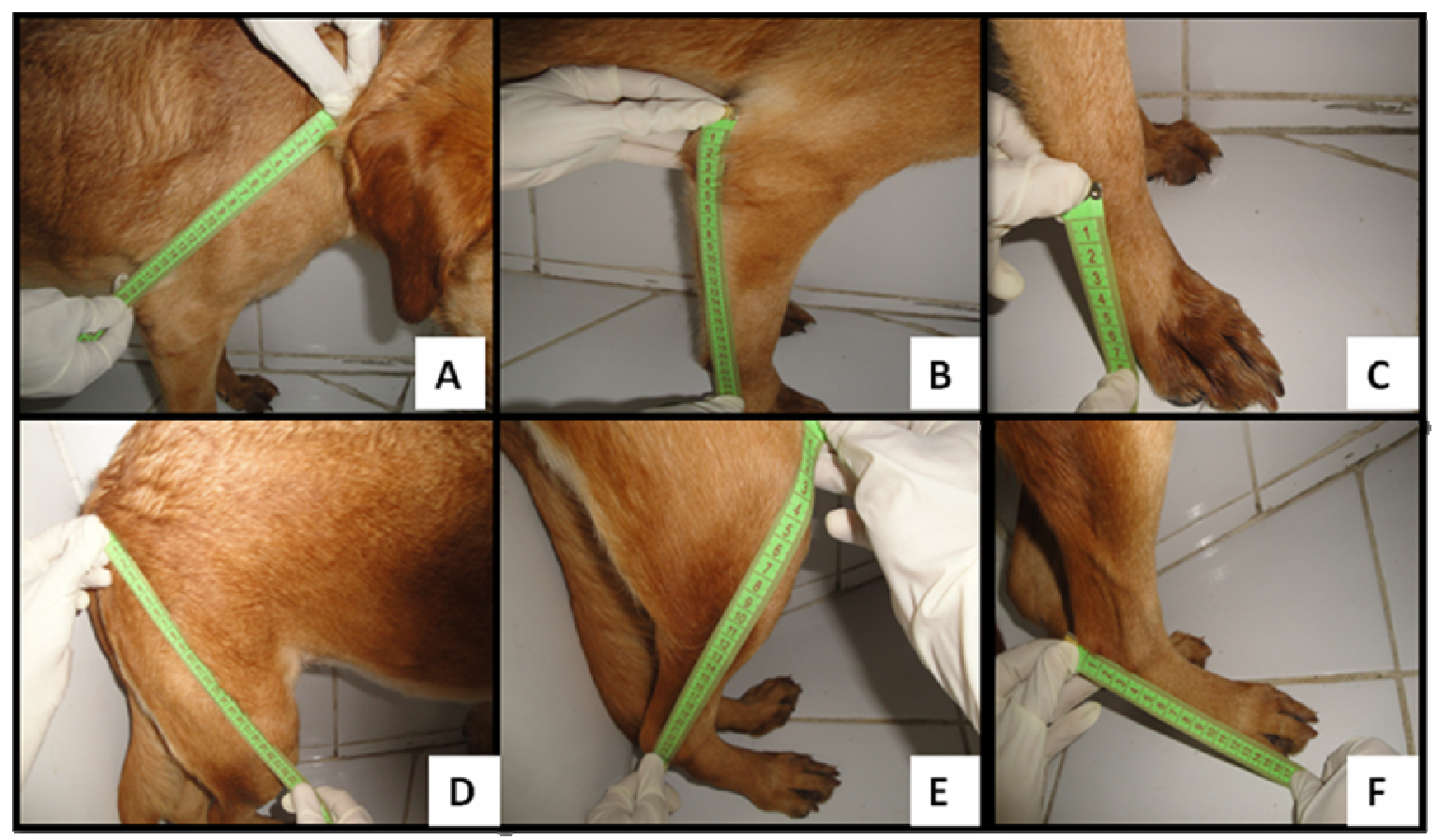

Figura 2 - Mensuração da biometria dos animais estudados. Em A mensuração do braço, em $\mathrm{B}$ antebraço, em $\mathrm{C}$ carpo, em D perna, em $\mathrm{E}$ tórax e em $\mathrm{F}$ tarso. 


\subsection{AVALIAÇÃO BIOMECÂNICA}

Os dados referentes à biomecânica da marcha foram coletados no Laboratório de Biomecânica da Escola de Educação Física e Esporte (EEFE) da Universidade de São Paulo. Foram realizadas as filmagens de vídeos e a coleta de força de reação do solo sincronizadamente, de cada um dos animais.

Afim de que os animais respondessem positivamente as coletas dos dados biomecânicos e estivessem adaptados ao ambiente, eles foram levadas três vezes por semana ao local da coleta para adaptação do espaço.

Para avaliação da cinemática da marcha, uma câmera digital com capacidade de aquisição de $60 \mathrm{~Hz}$ fixa a um tripé, foi colocada no plano transverso no sentido crâniocaudal do lado esquerdo de cada animal com uma distância de 4 metros (m).

A análise cinemática foi sincronizada com a coleta na plataforma de força. $\mathrm{O}$ animal fez o percurso passando pela plataforma, e para analise dos dados foi considerado o momento que o animal toca na plataforma até o momento em que o ultimo membro deixa de tocar plataforma. A figura ilustra o animal II Gaspar durante a coleta.

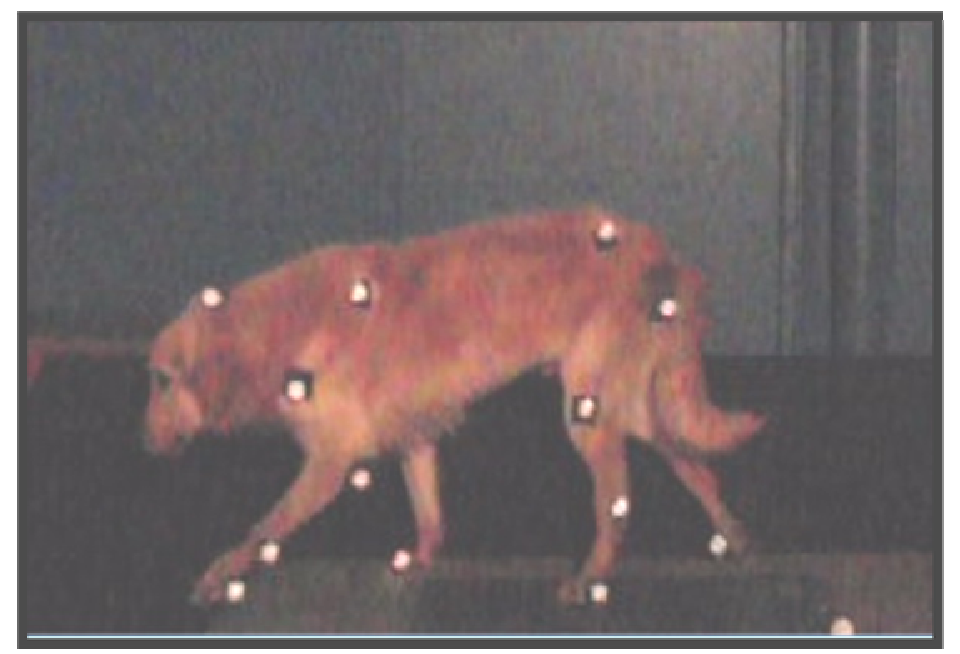

Figura 3 - Imagem coletada durante análise da marcha do animal II Gaspar. 
Fitas reflexivas foram posicionadas nos seguintes pontos anatômicos do hemicorpo esquerdo analisado na filmagem:

1. Espinha da escápula/acrômio;

2. Tubérculo maior do úmero,

3. Epicôndilo lateral do úmero;

4. Processo estilóide da ulna;

5. Cabeça do quinto metacarpo;

6. Crista ilíaca;

7. Trocânter maior do fêmur;

8. Côndilo femoral;

9. Maléolo lateral;

10. Cabeça do quinto metatarso;

11. Crista do occipital;

12. Cabeça do segundo metatarso contralateral;

13. Cabeça do segundo metacarpo contralateral.

A figura 4 ilustra esses pontos anatômicos no hemicorpo esquerdo dos animais.

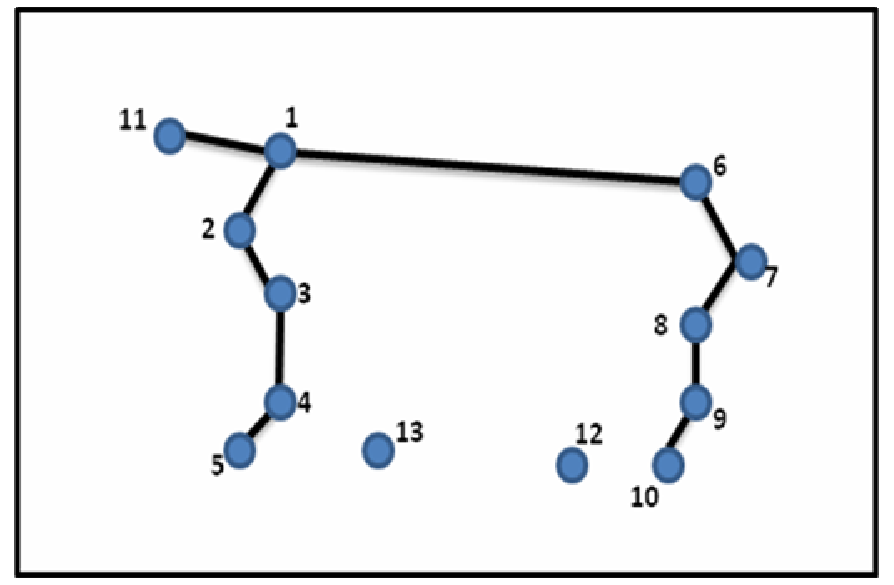

Figura 4 - esquema representando os pontos anatômicos no hemicorpo esquerdo para coleta das imagens. 
A partir das marcações dos pontos articulares foram analisados os ângulos articulares expressos na figura 4.

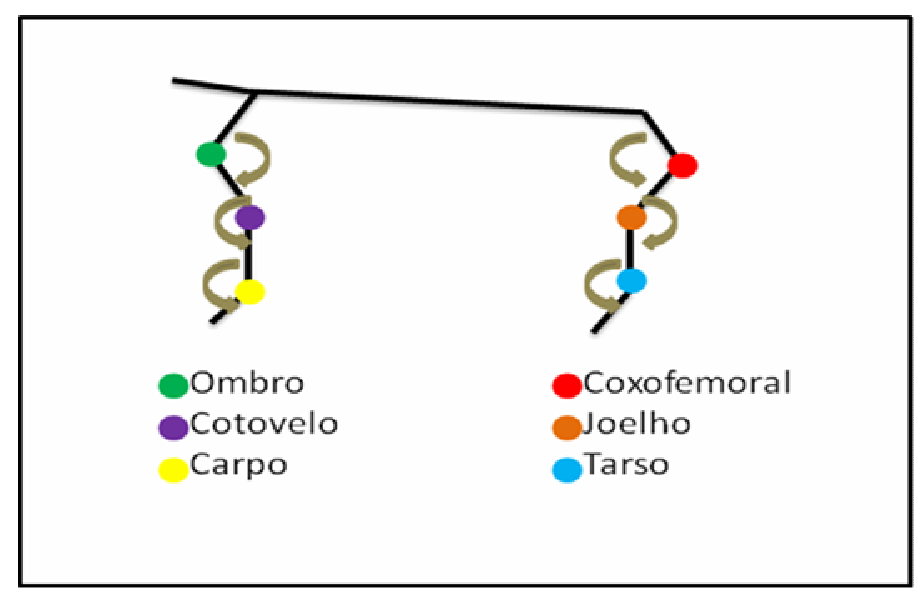

Figura 5 - Ângulos articulares analisados

Os movimentos analisados durante as fases da marcha foram: flexão: diminuição do ângulo articular; extensão: aumento do ângulo articular.

Para a captação dos dados cinemáticos há a necessidade de calibração do espaço no qual será realizado o estudo. É necessário introduzir e filmar um objeto calibrador com coordenadas conhecidas. A extensão do espaço calibrado é de fundamental importância já que os métodos de reconstrução são mais precisos dentro do espaço calibrado (NIGG et al., 1994).

O ambiente deve estar com mínima iluminação e um refletor foi utilizado para aumentar a iluminação das marcas reflexivas colocadas nos pontos anatômicos de cada animal.

O movimento foi analisado no plano sagital, através de uma analise bidimensional, com a utilização de uma única câmera.

O Sistema Apas foi utilizado para registrar o posicionamento e deslocamento dos segmentos corporais durante a marcha, e também para controle da aquisição, leitura, digitalização, tratamento, armazenamento dos parâmetros cinemáticos. A figura 6 ilustra a página inicial desse sistema. 
Apasview - Apasview1

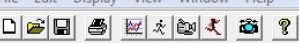

- $G$ Graph View

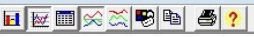

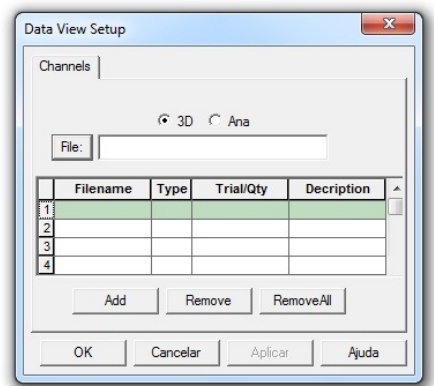

Figura 6 - Figura ilustrando a página inicial do Sistema Apas

Para a coleta da força de reação do solo (FRS) foi utilizada uma plataforma composta de transdutores de força ST-emed da empresa Novel, com superfície de medição de 690x403x19(22), com 6080 sensores e capacidade máxima de força de $193000 \mathrm{~N}$.

As coletas de FRS foram feitas sincronizadamente com as coletas dos dados cinemáticos considerando também o momento em que o primeiro membro do animal toca a plataforma até o momento em que o ultimo membro deixa a plataforma.

Um programa da mesma empresa ST-emed foi utilizado para registrar variáveis de força de reação ao solo de cada animal estudado. Após o sistema MATLAB foi utilizado para tratamento e análise final dos resultados. A figura 7 ilustra a página inicial desse sistema. 


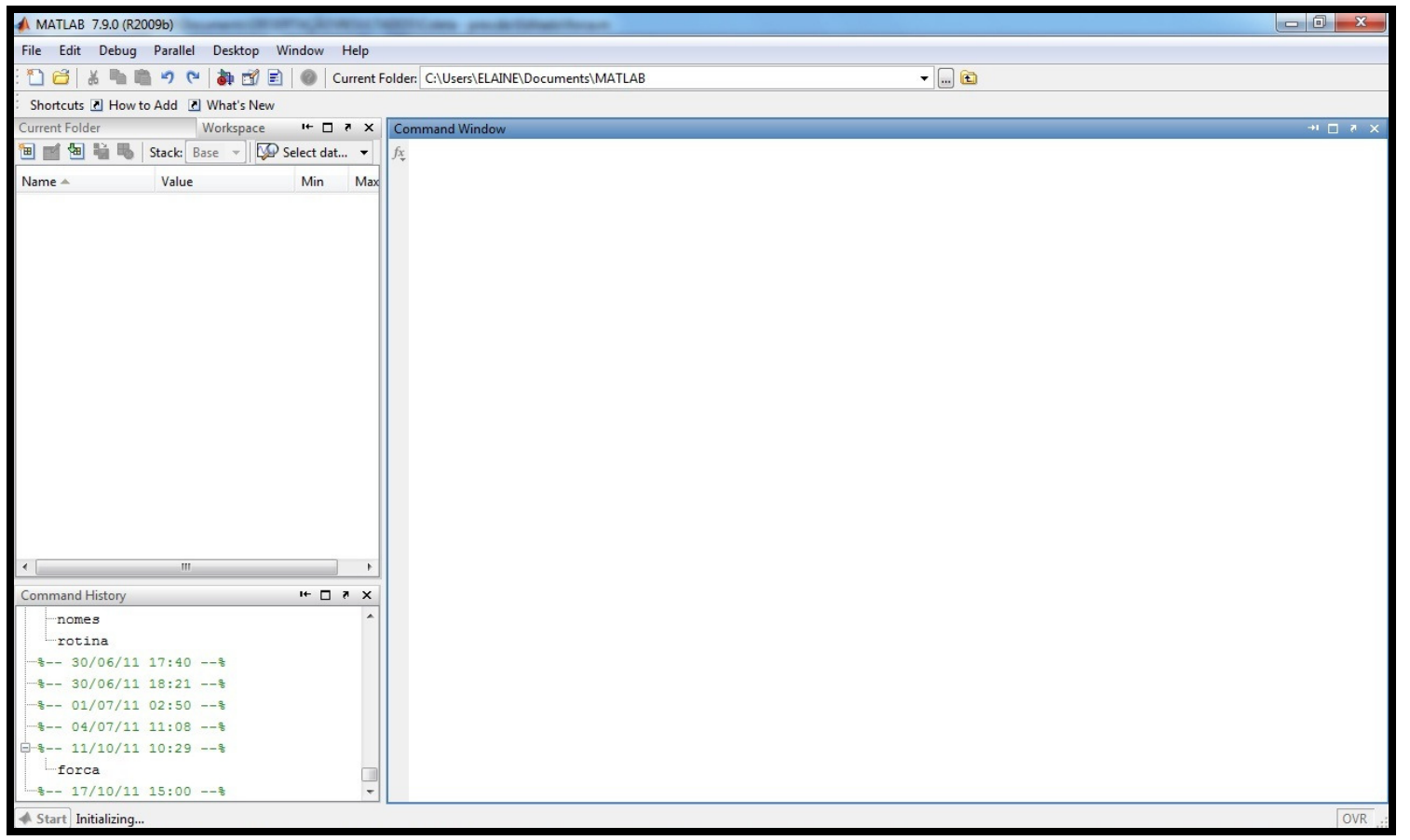

Figura 7 - Figura ilustrando a página inicial do sistema MATLAB

Para análises estatísticas foi utilizado o método de GraphPad para verificar se os valores relacionados a cada variável respeiram um distribuição normal de Gauss, considerando o nível de normalidade $\mathrm{p}>0.10$. 


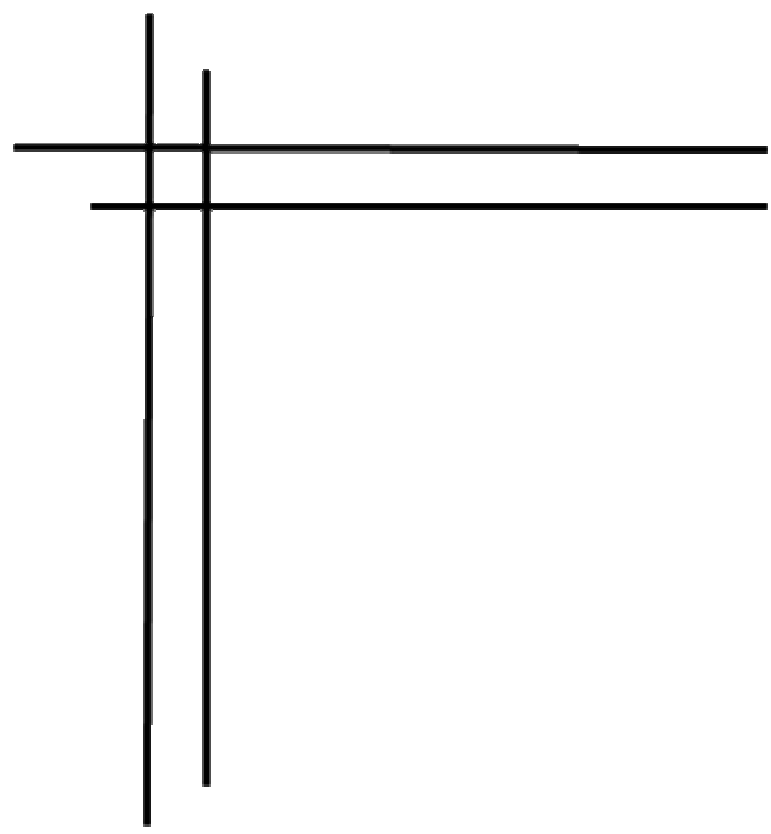

Resultados 


\section{RESULTADOS}

Foram analisadas variáveis biométricas como peso, altura, comprimentos de braço, antebraço, perna, coxa e diâmetro de tórax de cada animal, além de variáveis cinemáticas como angulação mínima e máxima das articulações do tarso, joelho, coxofemoral, ombro, cotovelo e carpo além das variáveis dinâmicas como a força de reação ao solo que animal sofre no desenvolver da marcha.

\subsection{ANÁLISE DA BIOMETRIA}

O comprimento do braço, antebraço, carpo, coxa, perna e tarso foram analisados apena no antímero esquerdo de cada um dos cães, lado também utilizado para as filmagens. Os parâmetros morfométricos dos seis animais distróficos estão descritos na tabela 2.

Tabela 2 - Média dos valores dos dados biométricos dos seis animais estudados.

\begin{tabular}{cccc}
\hline Variáveis & Unidade & Média & Desvio padrão \\
\hline Braço & $(\mathrm{cm})$ & 16,69 & 0,69 \\
Antebraço & $(\mathrm{cm})$ & 17,12 & 0,92 \\
Carpo & $(\mathrm{cm})$ & 5,16 & 0,60 \\
Coxa & $(\mathrm{cm})$ & 18,91 & 0,75 \\
Perna & $(\mathrm{cm})$ & 19,03 & 1,34 \\
Tarso & $(\mathrm{cm})$ & 10,98 & 0,73 \\
Tórax & $(\mathrm{cm})$ & 67,54 & 1,98 \\
Altura & $(\mathrm{cm})$ & 52,14 & 0,87 \\
Peso & $(\mathrm{kg})$ & 20,44 & 2,32 \\
\hline
\end{tabular}


Para todas as análises biométricas analisadas foram aceitas a hipótese de normalidade pelo método GraphPad, valor de $\mathrm{p}>0.10$.

\subsection{VARIAÇÕES CINEMÁTICAS}

Cada articulação apresentou padrões característicos dos movimentos de flexão e extensão articular. Os picos de flexão, ou seja, a diminuição do ângulo formado pelos seguimentos daquela articulação ocorreu na fase de balanço, e o aumento do ângulo articular, ocorreu nas fases de apoio e propulsão do membro.

Foram analisados os movimentos de flexão e extensão por vídeo em seis vídeos para cada animal, considerando desde o momento que animal tocou na plataforma de pressão até o momento que retirou o ultimo membro da mesma.

Foram analisados separadamente os ângulos articulares de cada um dos sei animais estudados sempre considerando o momento que animal toca na plataforma até o momento que retira o ultimo membro.

Os gráficos abaixo ilustram esse movimento sendo a diminuição da curva representa a flexão da articulação, ou seja, uma diminuição do ângulo articular e o aumento da curva representam a extensão, ou seja, indica o aumento máximo do ângulo articular de cada animal separadamente.

\subsubsection{Animal I BIZ}

Neste animal podemos observar que no movimento da articulação escapuloumeral a angulação máxima de $132.8^{\circ} \pm 8.07$ e angulação mínima de $119.2^{\circ} \pm 10.10$ durante a marcha. O gráfico 1 ilustra o comportamento dessa articulação durante a coleta. 


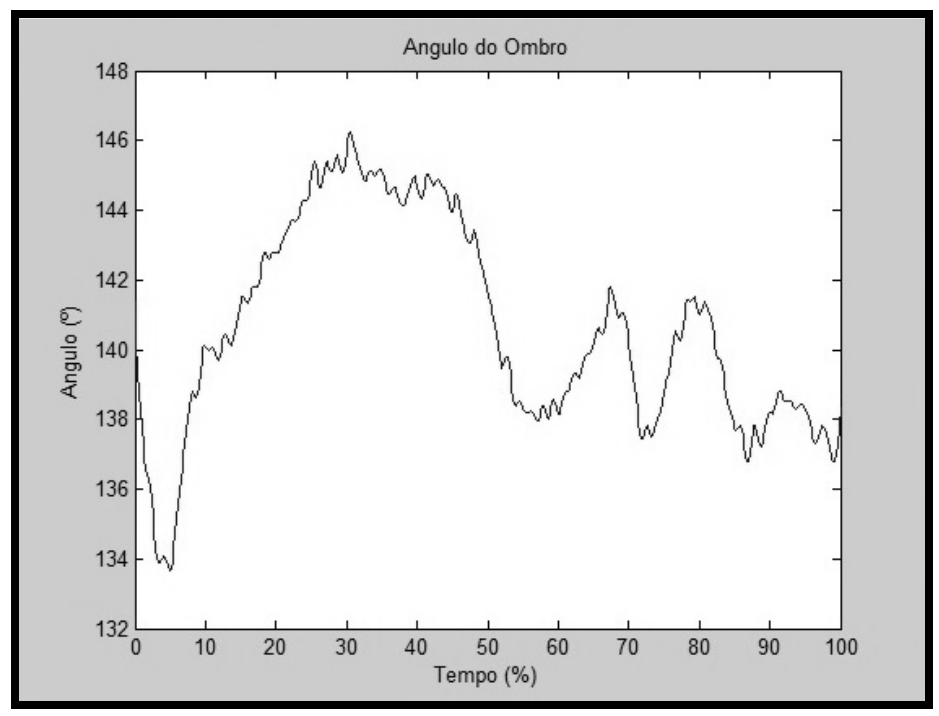

Gráfico 1- Movimento da articulação escapuloumeral do animal I Biz, durante as fases de balanço, apoio e propulsão. A diminuição na curva representa uma diminuição do ângulo articular e o aumento da curva indica um aumento do ângulo articular

$\mathrm{Na}$ articulação umeroradioulnar a angulação máxima de $133^{\circ} \pm 7.38$ e angulação mínima de $120.2^{\circ} \pm 9.62$ durante a marcha. $\mathrm{O}$ gráfico 2 ilustra o comportamente dessa articulação durante a coleta.

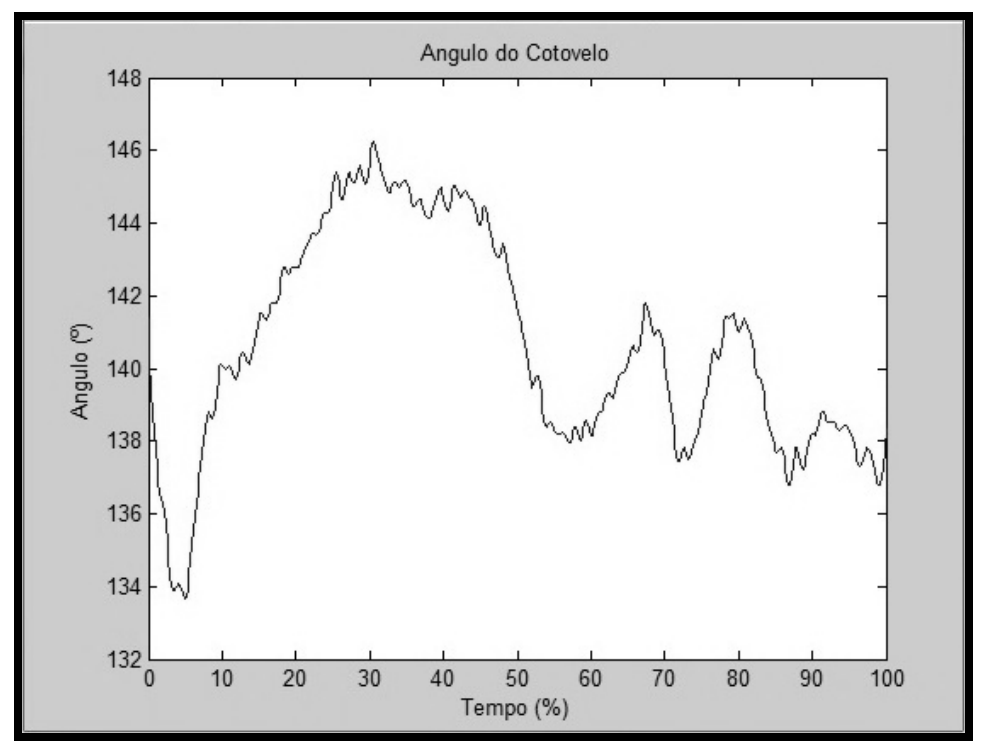

Gráfico 2 - Movimento da articulação umeroradioulnar do animal I Biz, durante as fases de balanço, apoio e propulsão. A diminuição na curva representa uma diminuição do ângulo articular e o aumento da curva indica um aumento do ângulo articular. 
$\mathrm{Na}$ articulação do carpo desse mesmo animal podemos observar uma angulação máxima de $133.2^{\circ} \pm 7.82$ e angulação mínima de $120.6^{\circ} \pm 9.44$ durante a marcha.O gráfico 3 ilustra o comportamento dessa articulação durante a coleta.

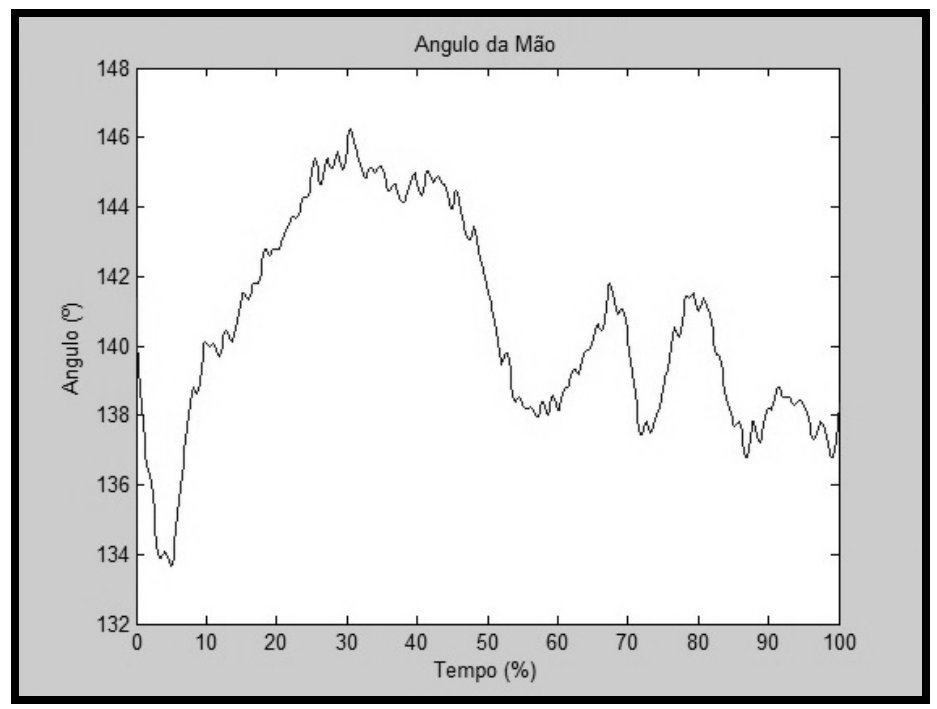

Gráfico 3- Movimento da articulação do carpo do animal I Biz, durante as fases de balanço, apoio e propulsão. A diminuição na curva representa uma diminuição do ângulo articular e o aumento da curva indica um aumento do ângulo articular.

$\mathrm{Na}$ articulação coxofemoral podemos observar uma angulação máxima de $132.2^{\circ}$ \pm 7.25 e angulação mínima de $119^{\circ} \pm 8.09$ durante a marcha. $\mathrm{O}$ gráfico 4 ilustra $\mathrm{o}$ comportamento dessa articulação durante a coleta. 


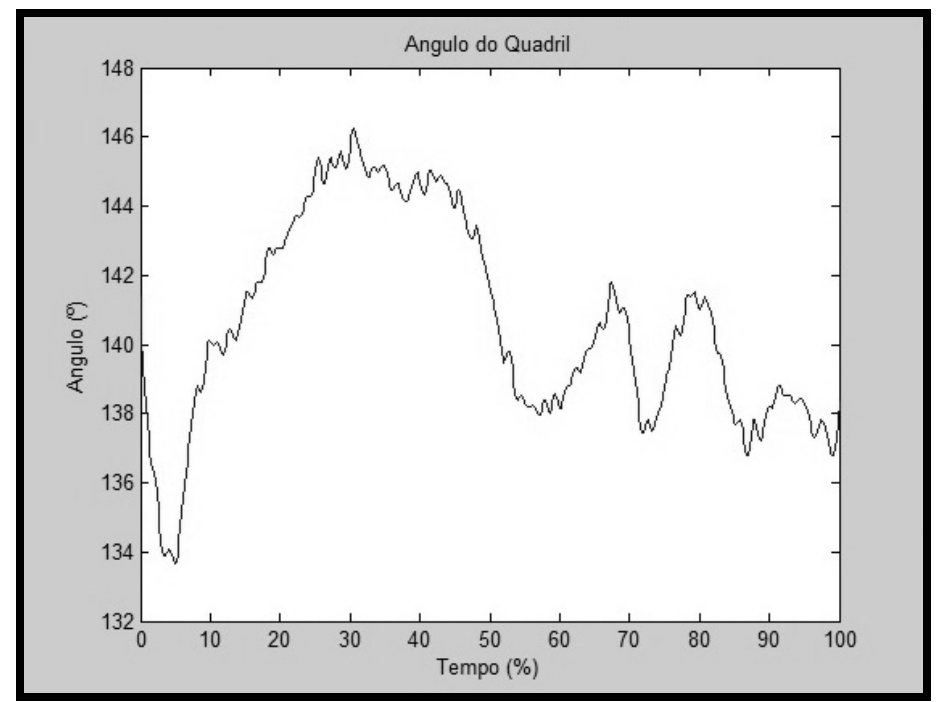

Gráfico 4- Movimento da articulação coxofemoral do animal I Biz, durante as fases de balanço, apoio e propulsão. A diminuição na curva representa uma diminuição do ângulo articular e o aumento da curva indica um aumento do ângulo articular.

$\mathrm{Na}$ articulação femortibiopatelar, podemos observar uma angulação máxima de $133^{\circ}$ \pm 7.38 e angulação mínima de $118.8^{\circ} \pm 10.25$ durante a marcha. $\mathrm{O}$ gráfico 5 representa $\mathrm{o}$ comportamento dessa articulação durante a coleta.

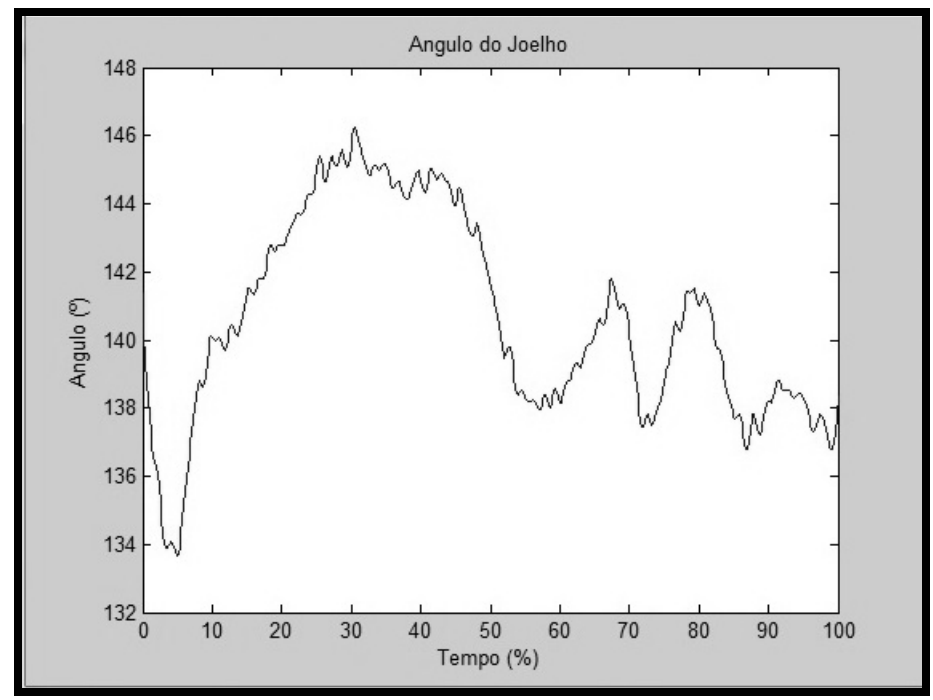

Gráfico 5- Movimento da articulação femortibiopatelar do animal I Biz, durante as fases de balanço, apoio e propulsão. A diminuição na curva representa uma diminuição do ângulo articular e o aumento da curva indica um aumento do ângulo articular. 
Já na articulação do tarso, podemos observar no movimento articular uma angulação máxima de $133^{\circ} \pm 7.38$ e angulação mínima de $119^{\circ} \pm 9.59$ durante a marcha. O gráfico 6 representa o comportamento dessa articulação durante a marcha.

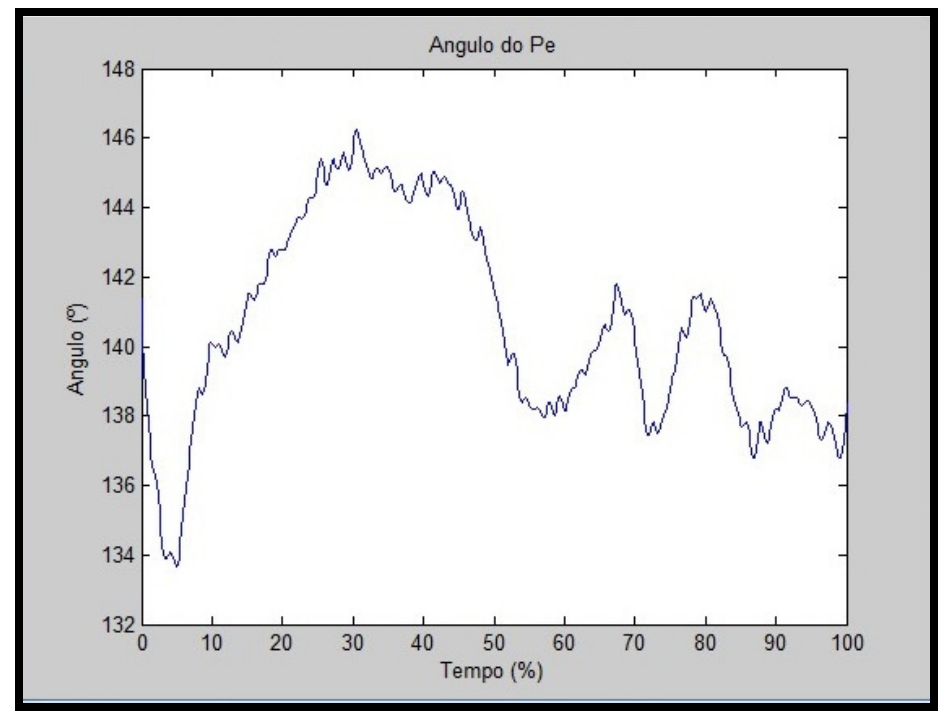

Gráfico 6- Movimento da articulação do tarso do animal I Biz, durante as fases de balanço, apoio e propulsão. A diminuição na curva representa uma diminuição do ângulo articular e o aumento da curva indica um aumento do ângulo articular.

\subsubsection{ANIMAL II GASPAR}

Neste animal podemos observar no movimento da articulação escapuloumeral uma angulação máxima de $136.6^{\circ} \pm 2.07$ e angulação mínima de $107.6^{\circ} \pm 4.92$ durante a marcha. O gráfico 7 representa o comportamento dessa articulação durante a coleta. 


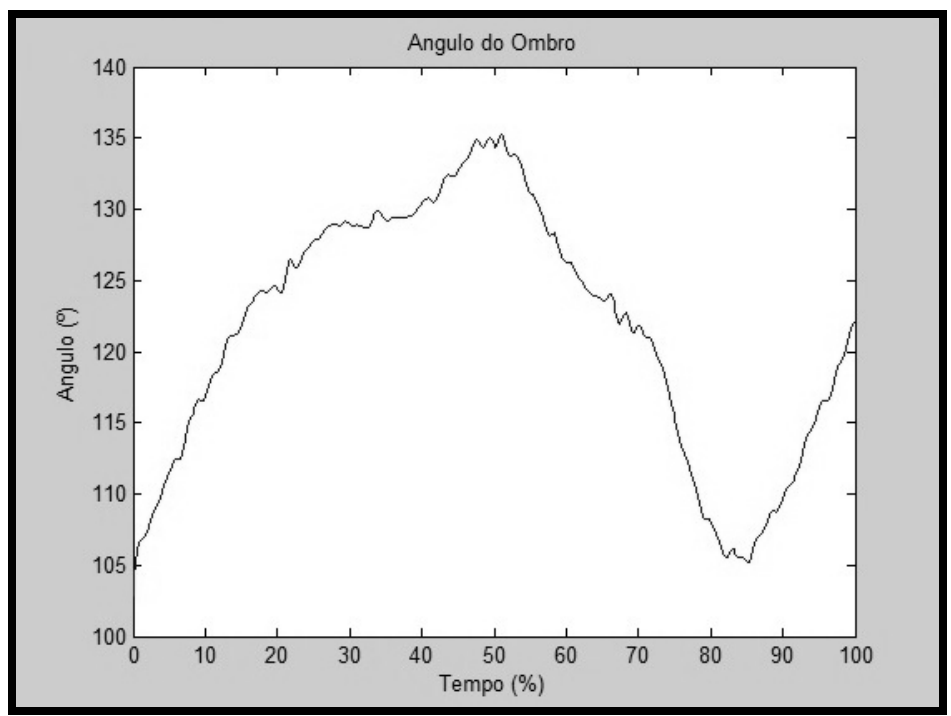

Gráfico 7 - Movimento da articulação escapuloumeral do animal II Gaspar, durante as fases de balanço, apoio e propulsão. A diminuição na curva representa uma diminuição do ângulo articular e o aumento da curva indica um aumento do ângulo articular.

$\mathrm{Na}$ articulação umeroradioulnar foi observado à angulação máxima de $136.4^{\circ} \pm 1.94$ e angulação mínima de $106.6^{\circ} \pm 5.54$ durante a marcha. O gráfico 8 ilustra o comportamento dessa articulação durante as coletas.

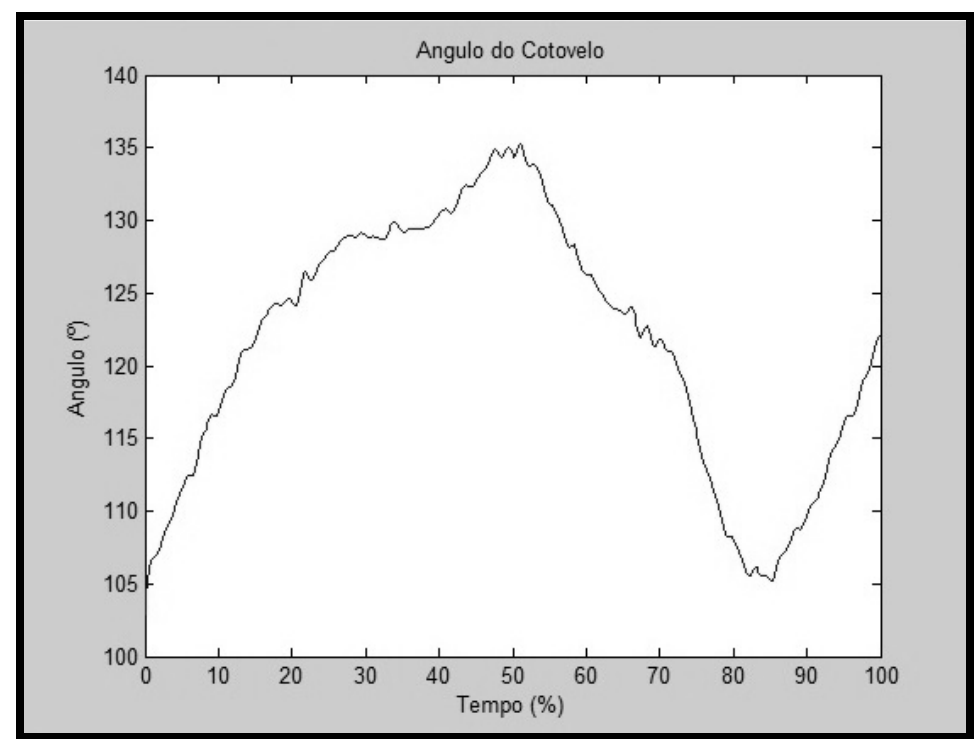

Gráfico 8- Movimento da articulação umeroradioulnar do animal II Gaspar, durante as fases de balanço, apoio e propulsão. A diminuição na curva representa uma diminuição do ângulo articular e o aumento da curva indica um aumento do ângulo articular. 
$\mathrm{Na}$ articulação do carpo desse mesmo animal podemos observar a angulação máxima de $136.4^{\circ} \pm 1.81$ e angulação mínima de $107^{\circ} \pm 5.26$ durante a marcha. $\mathrm{O}$ gráfico 9 ilustra o comportamento dessa articulação durante a coleta.

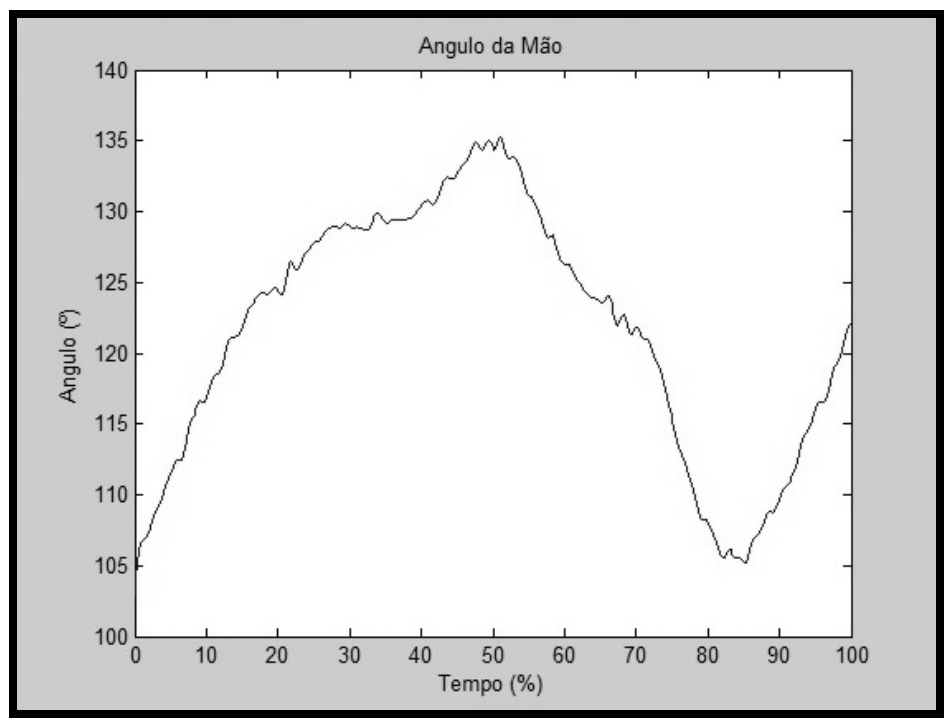

Gráfico 9- Movimento da articulação do carpo do animal II Gaspar, durante as fases de balanço, apoio e propulsão. A diminuição na curva representa uma diminuição do ângulo articular e o aumento da curva indica um aumento do ângulo articular.

$\mathrm{Na}$ articulação coxofemoral observamos no movimento articular uma angulação máxima de $136.8^{\circ} \pm 1.92$ e angulação mínima de $108^{\circ} \pm 4.69$ durante a marcha. $\mathrm{O}$ gráfico 10 representa o comportamento dessa articulação durante a coleta.

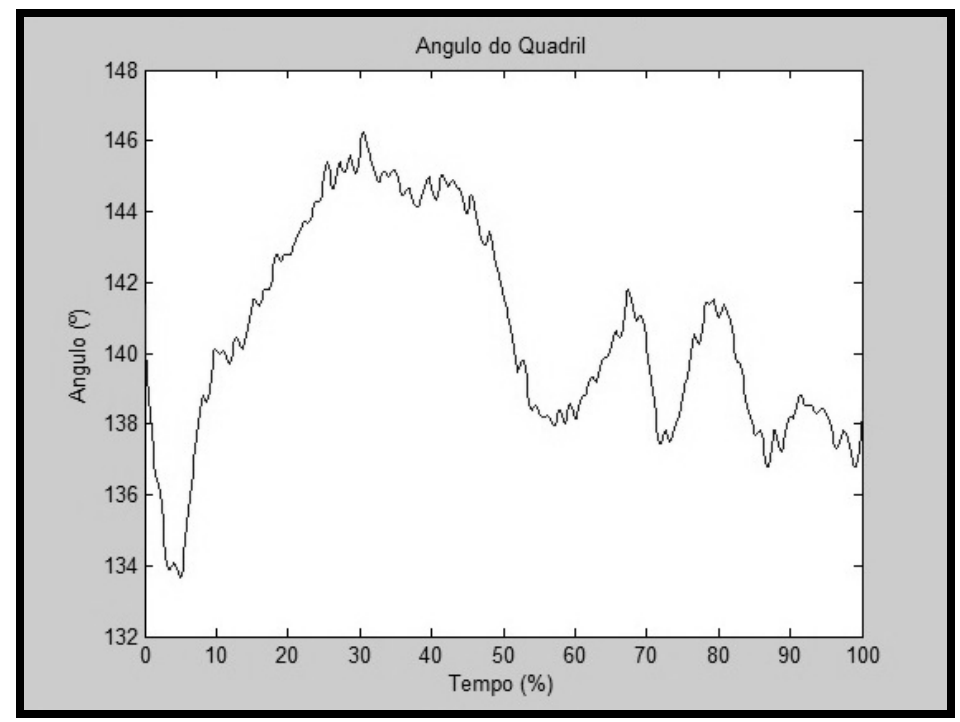

Gráfico 10- Movimento da articulação coxofemoral do animal II Gaspar, durante as fases de balanço, apoio e propulsão. A diminuição na curva representa uma diminuição do ângulo articular e o aumento da curva indica um aumento do ângulo articular. 
$\mathrm{Na}$ articulação femortibiopatelar, observamos uma angulação máxima de $136.6^{\circ}$ \pm 2.07 e angulação mínima de $108^{\circ} \pm 4.74$ durante a marcha. O gráfico 11 ilustra o comportamento dessa articulação durante a coleta.

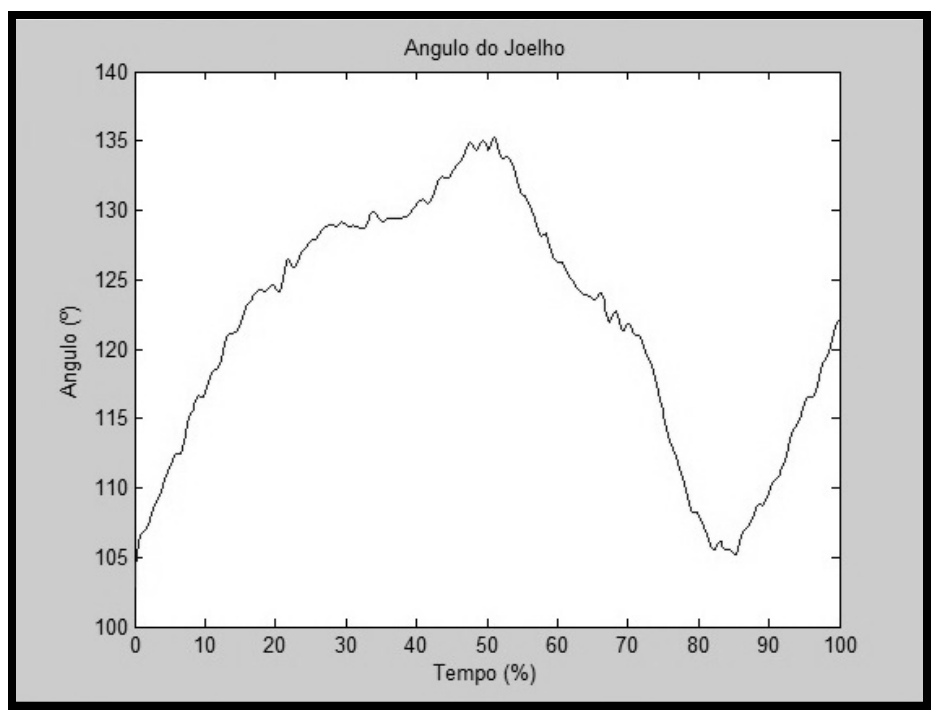

Gráfico 11- Movimento da articulação femortibiopatelar do animal II Gaspar, durante as fases de balanço, apoio e propulsão. A diminuição na curva representa uma diminuição do ângulo articular e o aumento da curva indica um aumento do ângulo articular.

Já na articulação do tarso, observamos a angulação máxima de $136.8^{\circ} \pm 1.92 \mathrm{e}$ angulação mínima de $108.2^{\circ} \pm 4.60$ durante a marcha. O gráfico 12 ilustra o comportamento dessa articulação durante a coleta. 


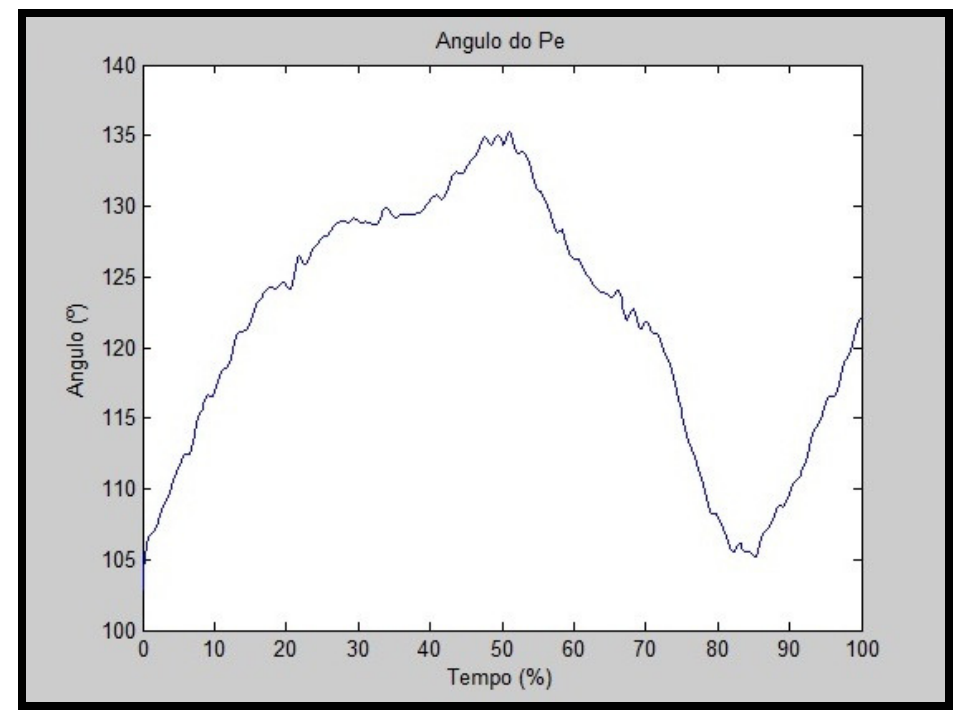

Gráfico 12- Movimento da articulação do tarso do animal II Gaspar, durante as fases de balanço, apoio e propulsão. A diminuição na curva representa uma diminuição do ângulo articular e o aumento da curva indica um aumento do ângulo articular.

\subsubsection{ANIMAL III LOLA}

Neste animal podemos observar no movimento da articulação escapuloumeral uma angulação máxima de $150.8^{\circ} \pm 6.26$ e angulação mínima de $123^{\circ} \pm 5.17$ durante a marcha. O gráfico 13 ilustra o comportamento dessa articulação durante a coleta.

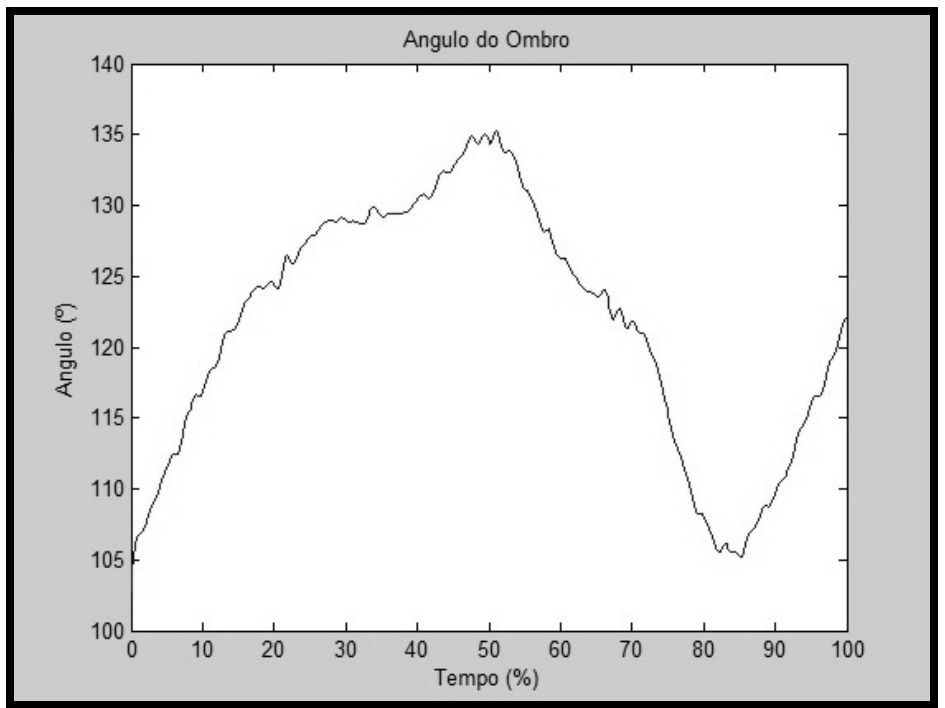

Gráfico 13- Movimento da articulação escapuloumeral do animal III Lola, durante as fases de balanço, apoio e propulsão. A diminuição na curva representa uma diminuição do ângulo articular e o aumento da curva indica um aumento do ângulo articular. 
$\mathrm{Na}$ articulação umeroradioulnar a angulação máxima foi de $151^{\circ} \pm 6.28$ e angulação mínima de $124^{\circ} \pm 5.47$ durante a marcha. O Gráfico 14 ilustra o comportamento dessa articulação durante a coleta.

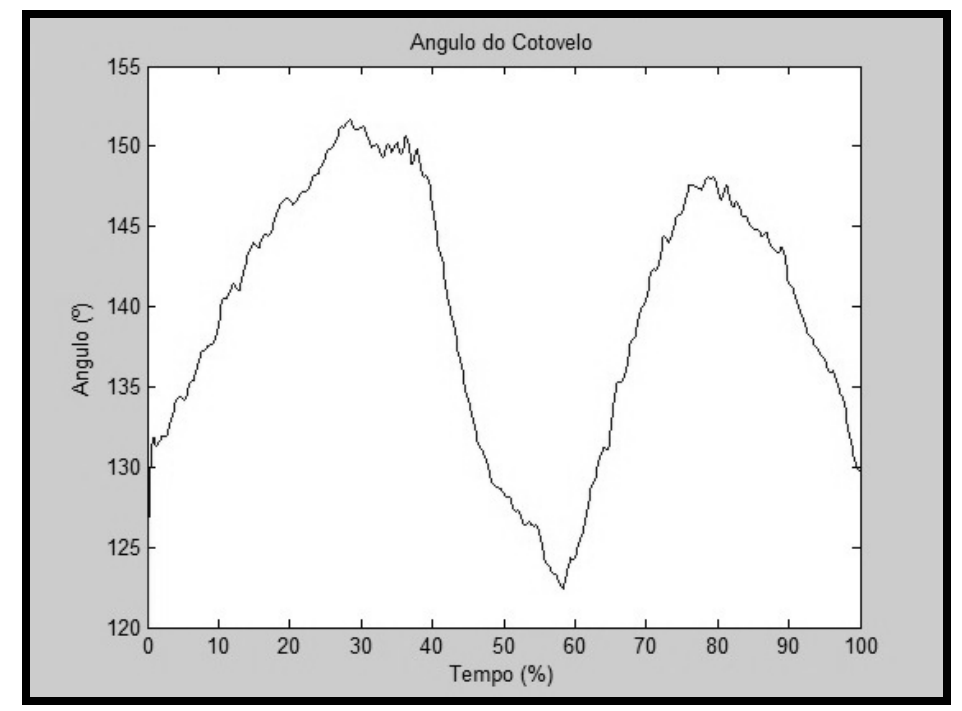

Gráfico 14- Movimento da articulação umeroradioulnar do animal III Lola, durante as fases de balanço, apoio e propulsão. A diminuição na curva representa uma diminuição do ângulo articular e o aumento da curva indica um aumento do ângulo articular.

$\mathrm{Na}$ articulação do carpo desse mesmo animal podemos observar a angulação máxima de $150.8^{\circ} \pm 6.26$ e angulação mínima de $124.6^{\circ} \pm 6.02$ durante a marcha. $\mathrm{O}$ gráfico 15 representa o comportamento dessa articulação durante e coleta. 


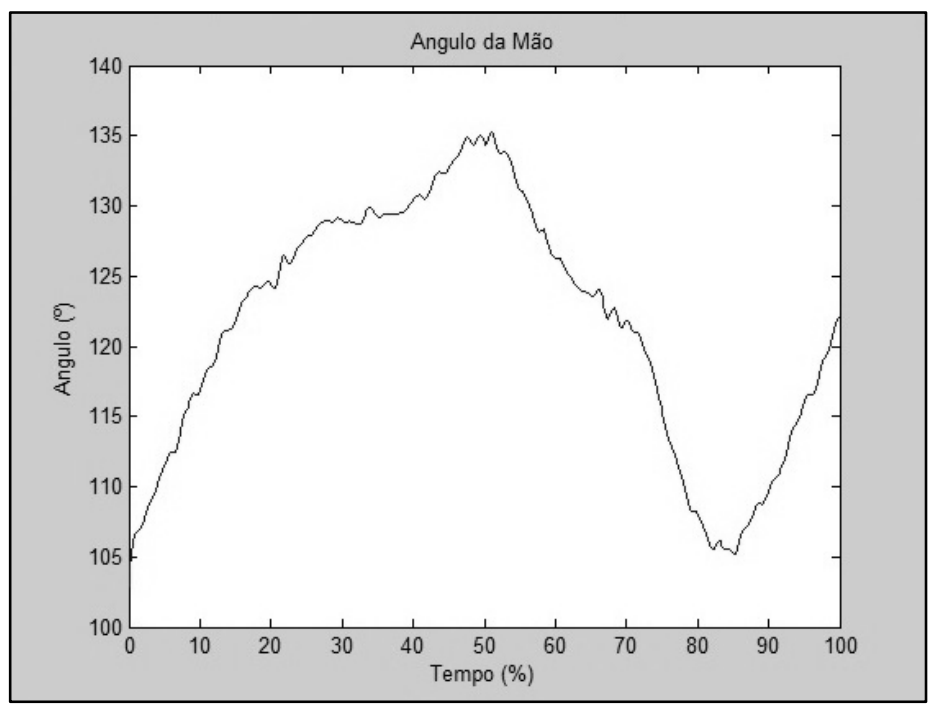

Gráfico 15- Movimento da articulação do carpo do animal III Lola, durante as fases de balanço, apoio e propulsão. A diminuição na curva representa uma diminuição do ângulo articular e o aumento da curva indica um aumento do ângulo articular.

$\mathrm{Na}$ articulação coxofemoral podemos observar no movimento articular uma angulação máxima de $151^{\circ} \pm 6.28$ e angulação mínima de $123.8^{\circ} \pm 5.97$ durante a marcha. O gráfico 16 ilustra o comportamento dessa articulação durante a coleta.

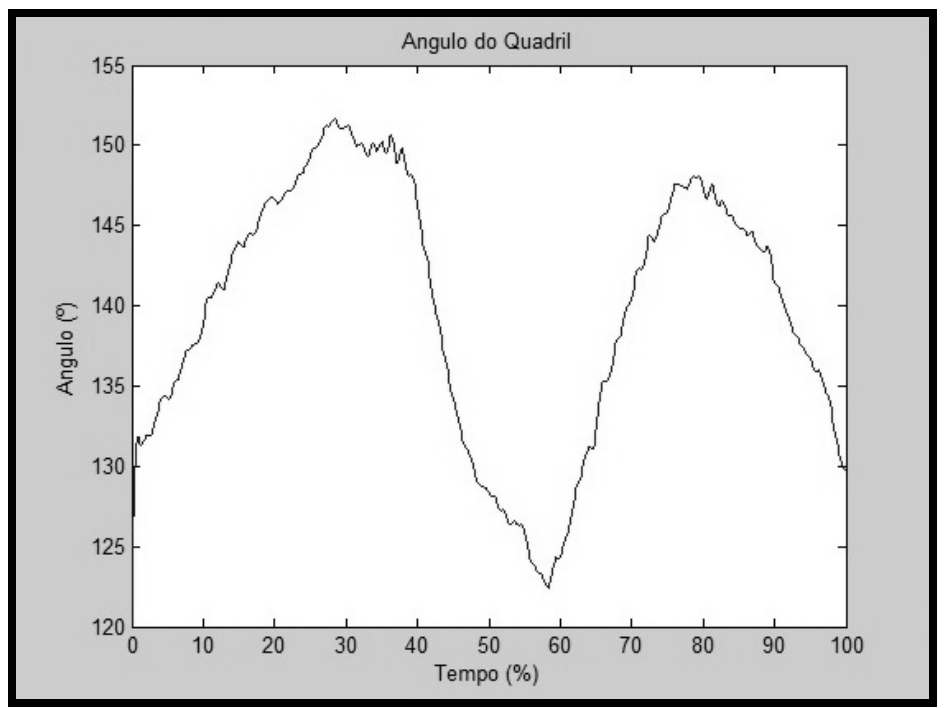

Gráfico 16- Movimento da articulação do coxofemoral do animal III Lola, durante as fases de balanço, apoio e propulsão. A diminuição na curva representa uma diminuição do ângulo articular e o aumento da curva indica um aumento do ângulo articular. 
$\mathrm{Na}$ articulação femortibiopatelar, podemos observar no movimento articular uma angulação máxima de $151^{\circ} \pm 6.28$ e angulação mínima de $123.6^{\circ} \pm 5.85$ durante a marcha. O gráfico 17 ilustra o comportamento dessa articulação durante a coleta.

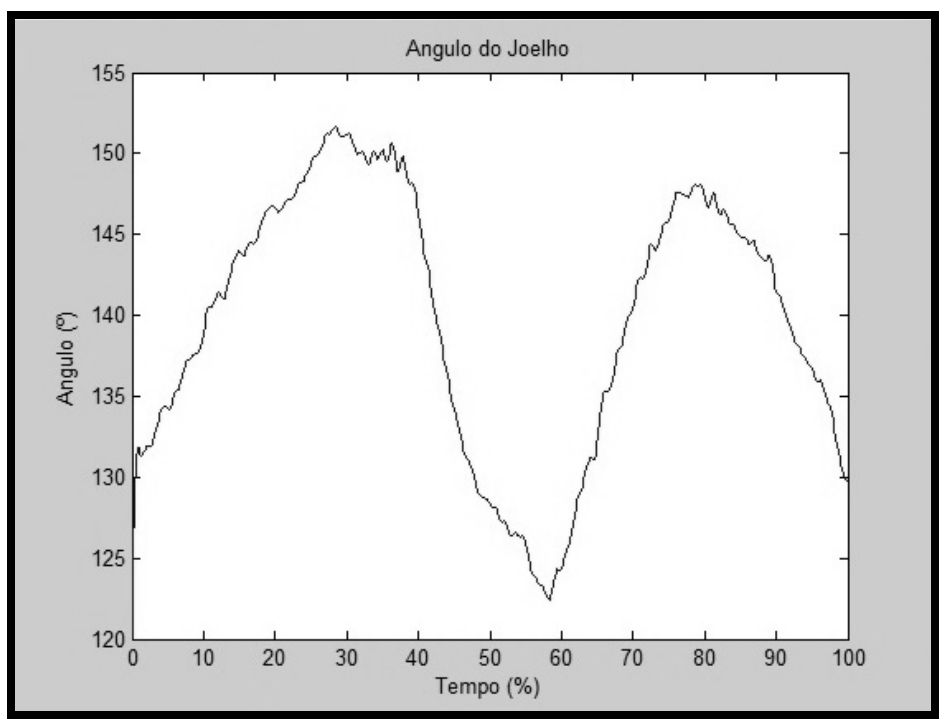

Gráfico 17- Movimento da articulação femortibiopatelar do animal III Lola, durante as fases de balanço, apoio e propulsão. A diminuição na curva representa uma diminuição do ângulo articular e o aumento da curva indica um aumento do ângulo articular.

Já na articulação do tarso, observamos no movimento articular uma angulação máxima de $150.8^{\circ} \pm 6.26$ e angulação mínima de $124.2^{\circ} \pm 5.93$ durante a marcha. $\mathrm{O}$ gráfico 18 ilustra o comportamento dessa articulação durante a coleta.

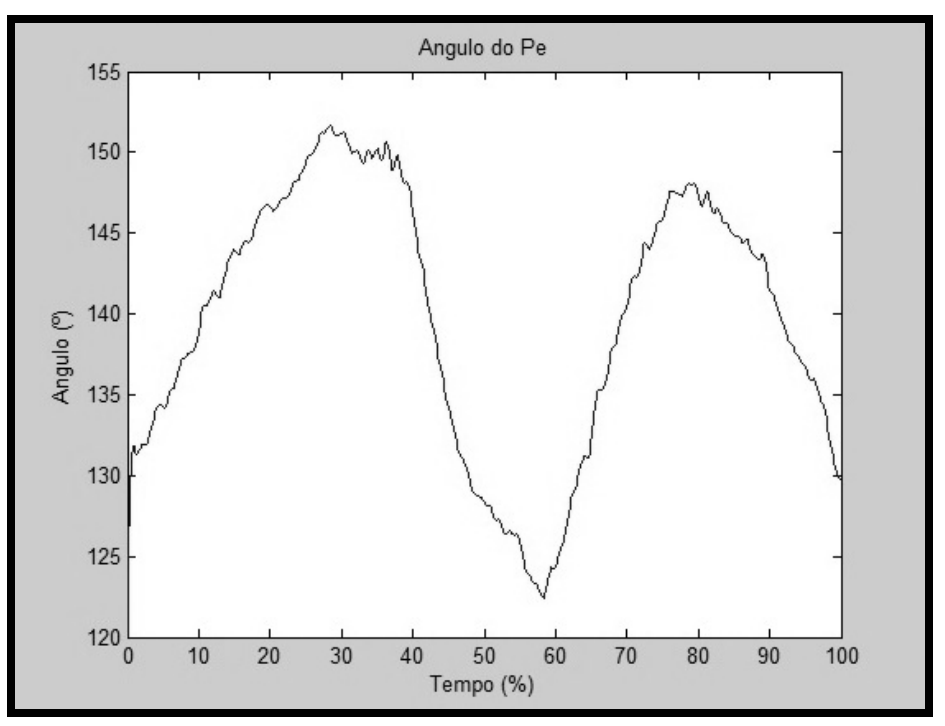

Gráfico 18- Movimento da articulação do tarso do animal III Lola, durante as fases de balanço, apoio e propulsão. A diminuição na curva representa uma diminuição do ângulo articular e o aumento da curva indica um aumento do ângulo articular. 


\subsubsection{ANIMAL IV LUCK}

Neste animal podemos observar no movimento da articulação escapuloumeral uma angulação máxima de $179.4^{\circ} \pm 0.89$ e angulação mínima de $139.8^{\circ} \pm 7.59$ durante a marcha. O gráfico 19 ilustra o comportamento dessa articulação durante a coleta.

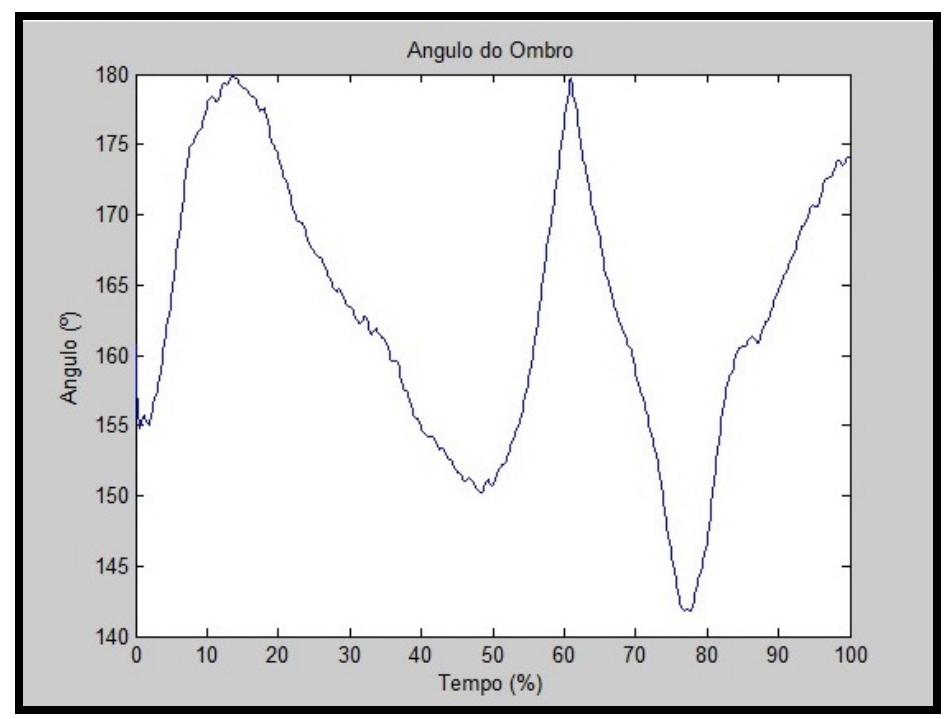

Gráfico 19- Movimento da articulação escapuloumeral do animal IV Luck, durante as fases de balanço, apoio e propulsão. A diminuição na curva representa uma diminuição do ângulo articular e o aumento da curva indica um aumento do ângulo articular.

$\mathrm{Na}$ articulação umeroradioulnar a angulação máxima foi de $179^{\circ} \pm 0.44$ e angulação mínima de $140.2^{\circ} \pm$ durante a marcha. O gráfico 20 ilustra o comportamento dessa articulação durante a coleta. 


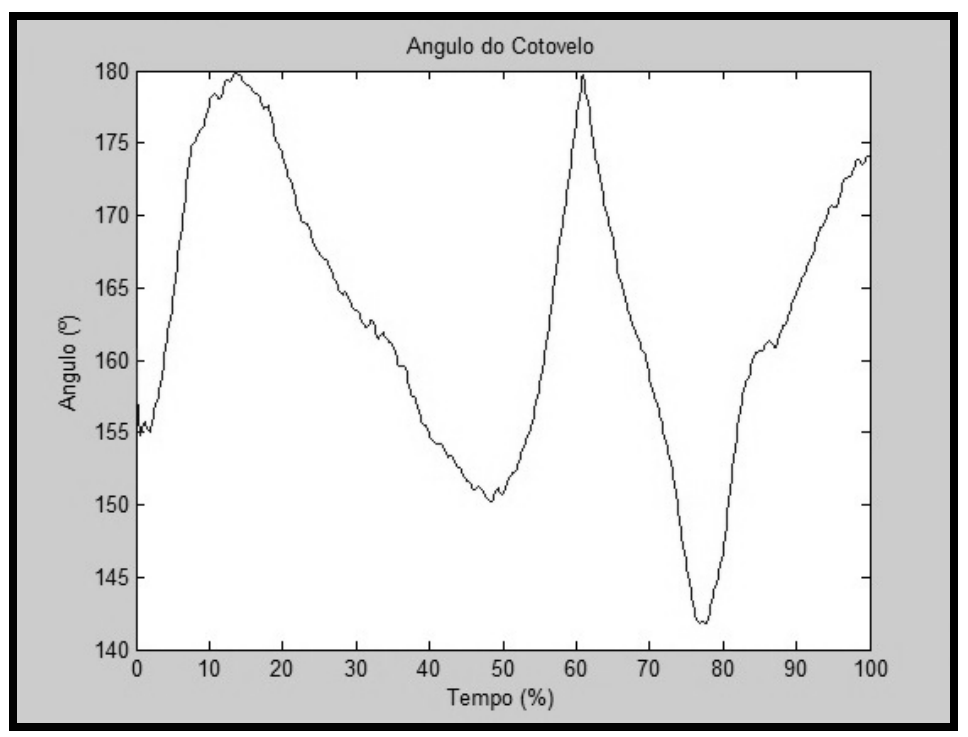

Gráfico 20- Movimento da articulação umeroradioulnar do animal IV Luck, durante as fases de balanço, apoio e propulsão. A diminuição na curva representa uma diminuição do ângulo articular e o aumento da curva indica um aumento do ângulo articular.

$\mathrm{Na}$ articulação do carpo desse mesmo animal podemos observar no movimento da articulação escapulo umeral uma angulação máxima de $179.4^{\circ} \pm 1.31$ e angulação mínima de $139.4^{\circ} \pm 6.76$ durante a marcha.

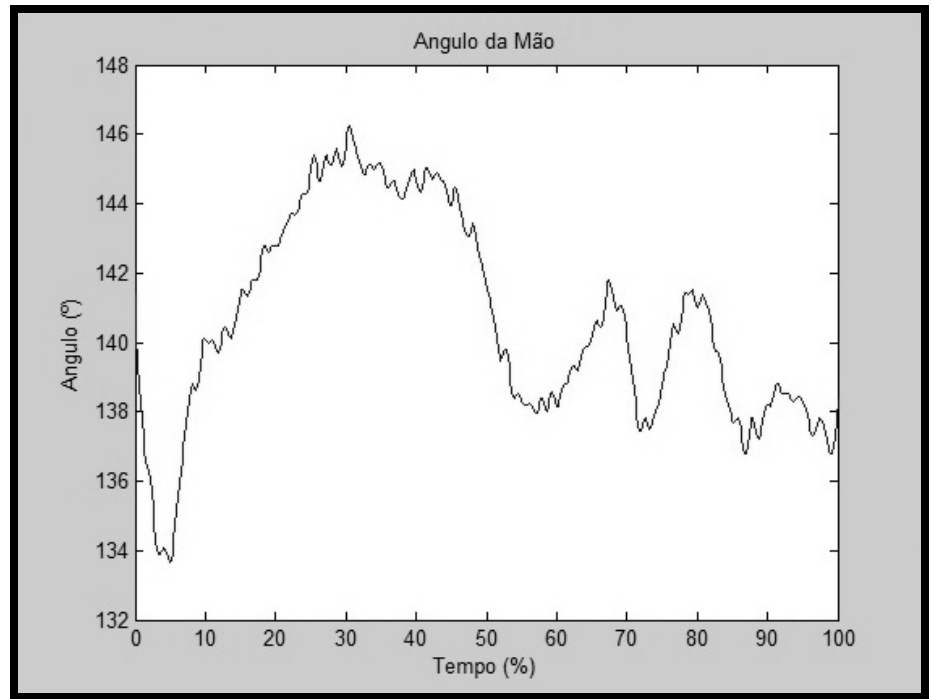

Gráfico 21- Movimento da articulação do carpo do animal IV Luck, durante as fases de balanço, apoio e propulsão. A diminuição na curva representa uma diminuição do ângulo articular e o aumento da curva indica um aumento do ângulo articular. 
$\mathrm{Na}$ articulação coxofemoral observamos a angulação máxima de $179.8^{\circ} \pm 0.44 \mathrm{e}$ angulação mínima de $140^{\circ} \pm 7.26$ durante a marcha. O gráfico 21 representa o comportamento dessa articulação durante a coleta.

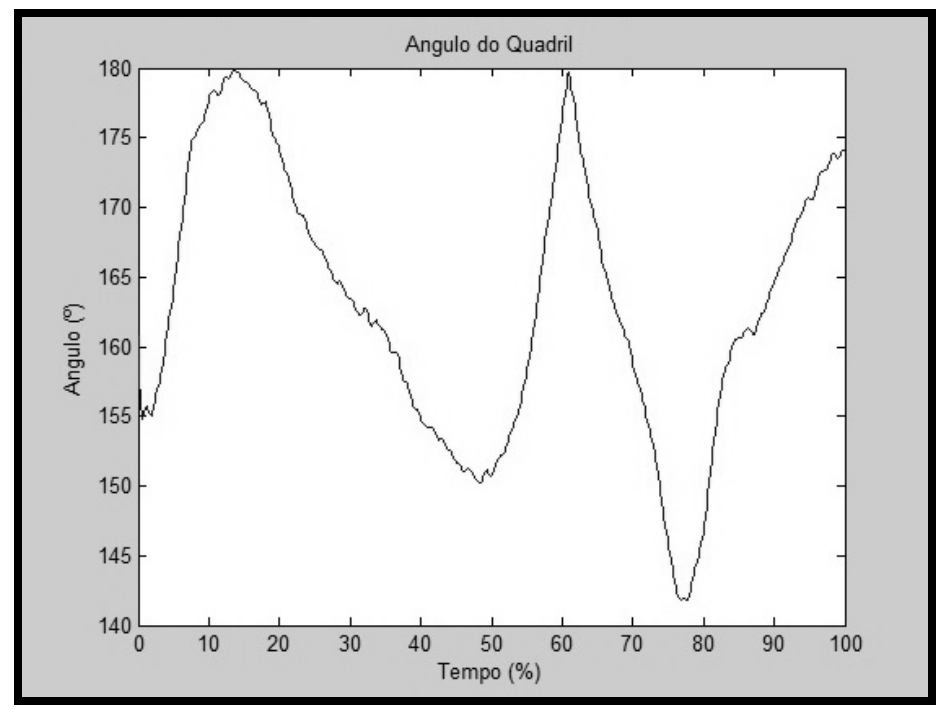

Gráfico 22- Movimento da articulação coxofemoral do animal IV Luck, durante as fases de balanço, apoio e propulsão. A diminuição na curva representa uma diminuição do ângulo articular e o aumento da curva indica um aumento do ângulo articular.

$\mathrm{Na}$ articulação femortibiopatelar, a angulação máxima foi de $179.4^{\circ} \pm 0.89 \mathrm{e}$ angulação mínima de $141^{\circ} \pm 7.81$ durante a marcha. $\mathrm{O}$ gráfico 22 representa $\mathrm{o}$ comportamente dessa articulação no momento da coleta. 


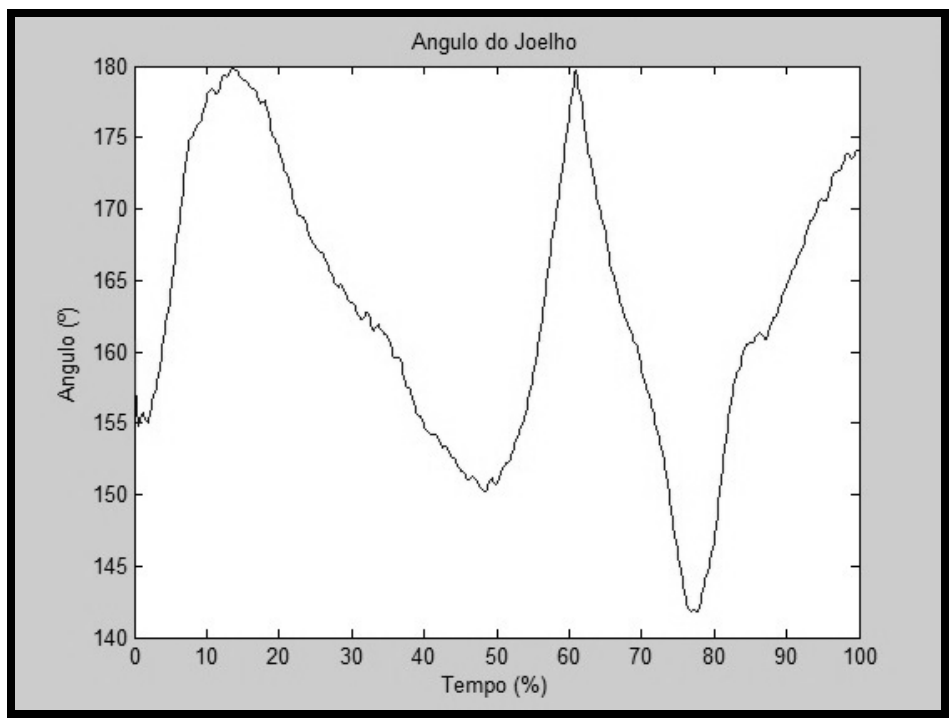

Gráfico 23- Movimento da articulação femortibiopatelar do animal IV Luck, durante as fases de balanço, apoio e propulsão. A diminuição na curva representa uma diminuição do ângulo articular e o aumento da curva indica um aumento do ângulo articular.

Já na articulação do tarso, podemos observamos a angulação máxima de $180^{\circ} \pm 0 \mathrm{e}$ angulação mínima de $139.8^{\circ} \pm 6.94$ durante a marcha. O gráfico 24 representa o comportamento dessa articulação durante a marcha.

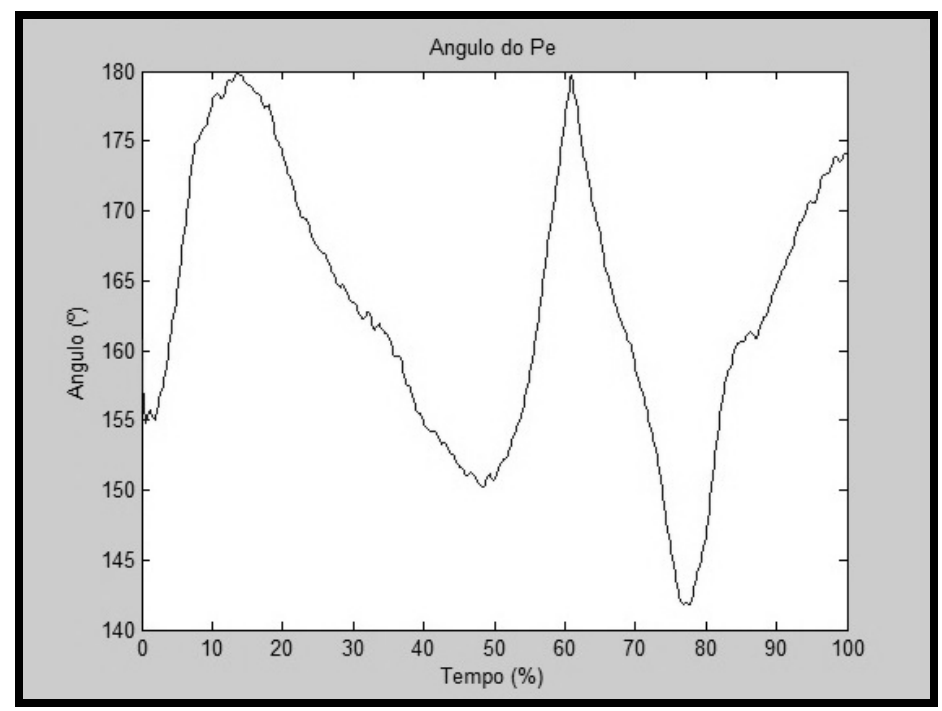

Gráfico 24- Movimento da articulação do tarso do animal IV Luck, durante as fases de balanço, apoio e propulsão. A diminuição na curva representa uma diminuição do ângulo articular e o aumento da curva indica um aumento do ângulo articular. 


\subsubsection{ANIMAL V MONSTRA}

Neste animal podemos observar no movimento da articulação escapuloumeral uma angulação máxima de $150^{\circ} \pm 0.89$ e angulação mínima de $127^{\circ} \pm 5.76$ durante a marcha. O gráfico 25 ilustra o comportamento dessa articulação durante a coleta em uma das tentativas analisadas.

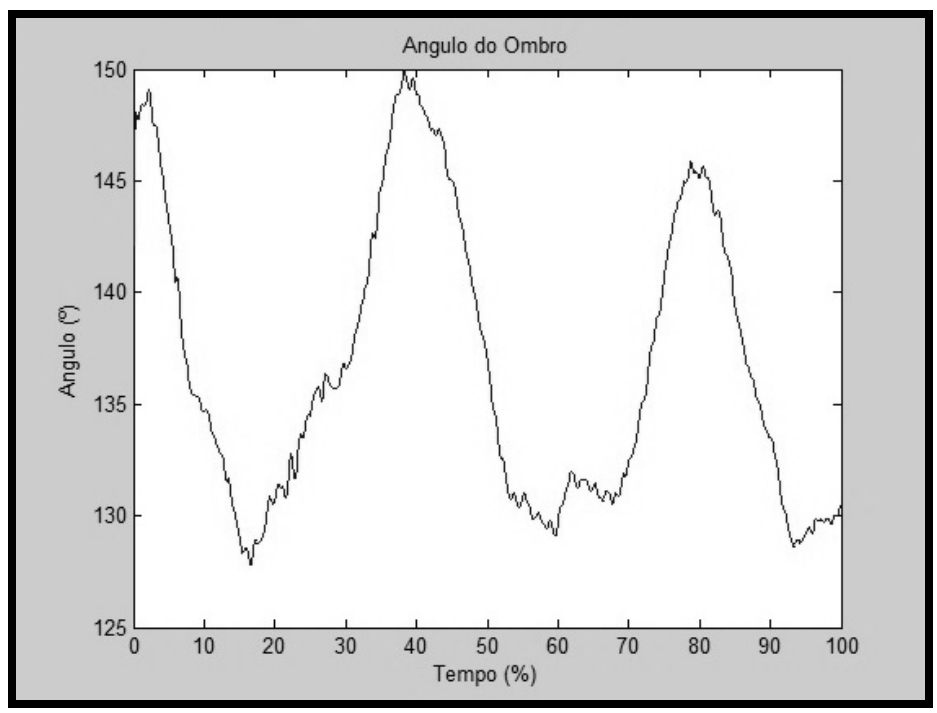

Gráfico 25- Movimento da articulação escapuloumeral do animal V Monstra, durante as fases de balanço, apoio e propulsão. A diminuição na curva representa uma diminuição do ângulo articular e o aumento da curva indica um aumento do ângulo articular.

$\mathrm{Na}$ articulação umeroradioulnar podemos observar no movimento articular uma angulação máxima de $148^{\circ} \pm 1.56$ e angulação mínima de $120^{\circ} \pm 7.39$ durante a marcha. O gráfico 26 ilustra o comportamento dessa articulação durante a coleta em uma das tentativas. 


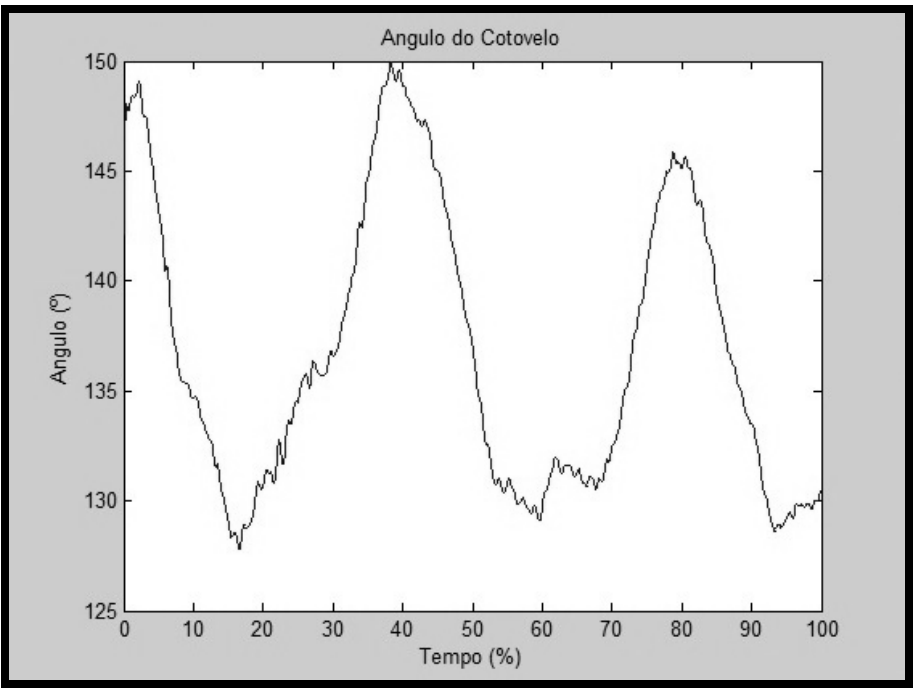

Gráfico 26-Movimento da articulação umeroradioulnar do animal V Monstra, durante as fases de balanço, apoio e propulsão. A diminuição na curva representa uma diminuição do ângulo articular e o aumento da curva indica um aumento do ângulo articular.

$\mathrm{Na}$ articulação do carpo desse mesmo animal podemos observar no movimento da articulação escapulo umeral uma angulação máxima de $149^{\circ} \pm 0.89$ e angulação mínima de $126^{\circ} \pm 7.58$ durante a marcha.

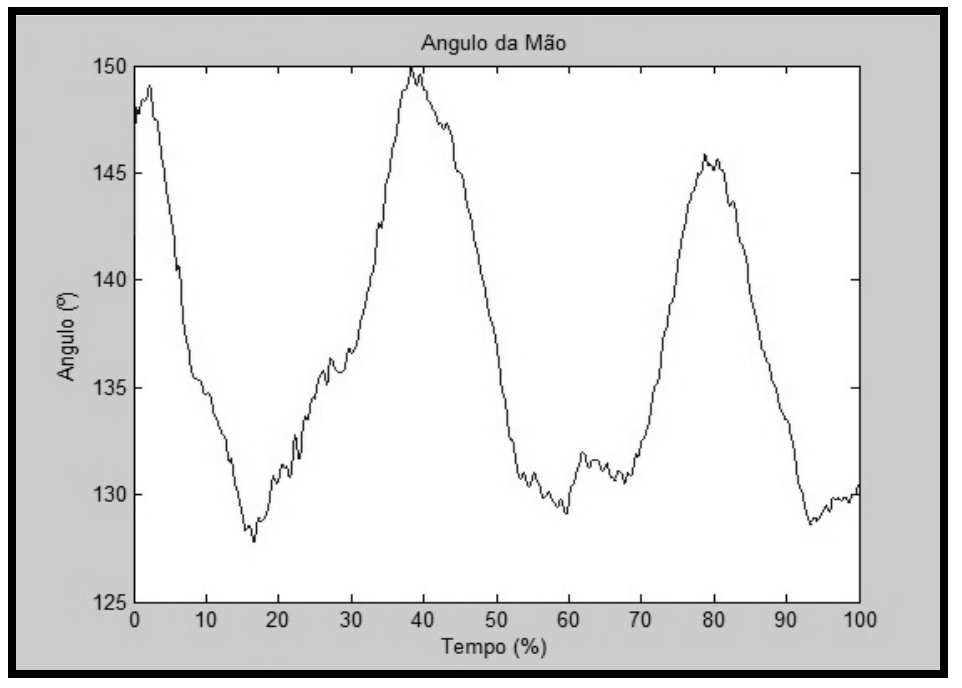

Gráfico 27 - Movimento da articulação do carpo do animal V Monstra, durante as fases de balanço, apoio e propulsão. A diminuição na curva representa uma diminuição do ângulo articular e o aumento da curva indica um aumento do ângulo articular.

$\mathrm{Na}$ articulação coxofemoral podemos observar no movimento articular uma angulação máxima de $150^{\circ} \pm 0.50$ e angulação mínima de $124^{\circ} \pm 5.89$ durante a marcha. 
O gráfico 26 ilustra o comportamento dessa articulação durante a coleta em uma das tentativa.

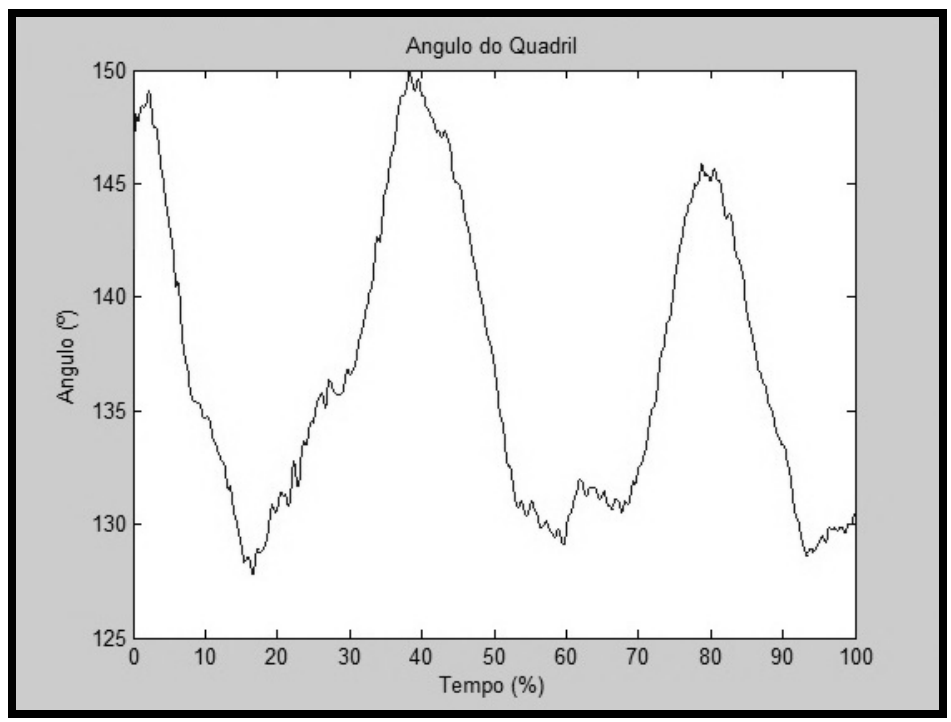

Gráfico 28- Movimento da articulação coxofemoral do animal V Monstra, durante as fases de balanço, apoio e propulsão. A diminuição na curva representa uma diminuição do ângulo articular e o aumento da curva indica um aumento do ângulo articular.

$\mathrm{Na}$ articulação femortibiopatelar, podemos observar no movimento articular uma angulação máxima de $152^{\circ} \pm 2.67$ e angulação mínima de $129^{\circ} \pm 8.42$ durante a marcha.

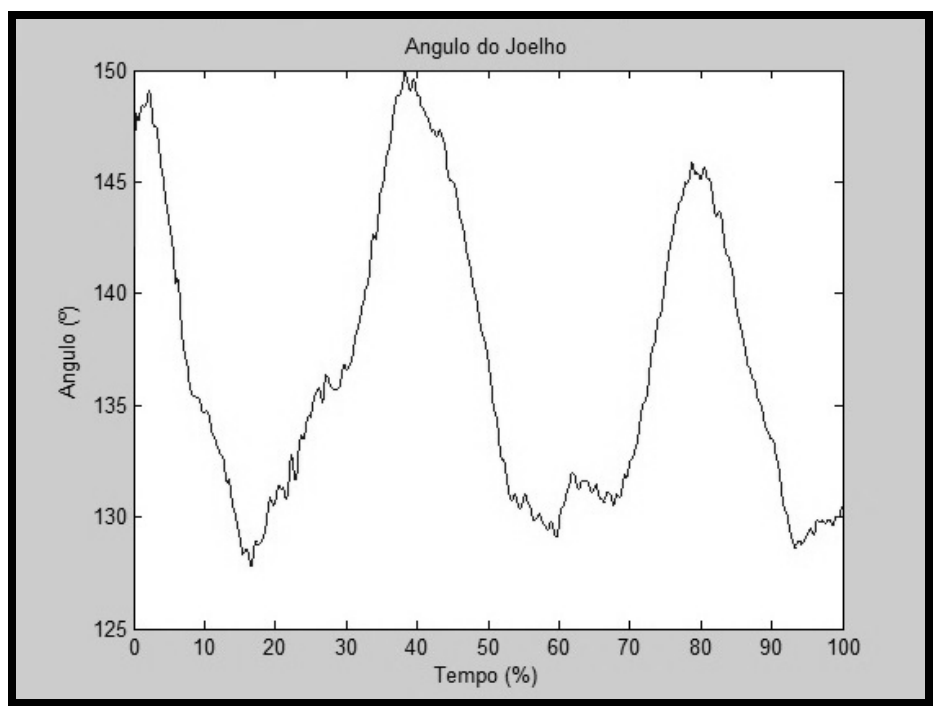

Gráfico 29- Movimento da articulação femortibiopatelar do animal V Monstra, durante as fases de balanço, apoio e propulsão. A diminuição na curva representa uma diminuição do ângulo articular e o aumento da curva indica um aumento do ângulo articular. 
Já na articulação do tarso, podemos observar no movimento articular uma angulação máxima de $150^{\circ} \pm 0$ e angulação mínima de $127^{\circ} \pm 4.96$ durante a marcha. $\mathrm{O}$ gráfico 30 ilustra o comportamento dessa articulação durante a coleta em uma das tentativas.

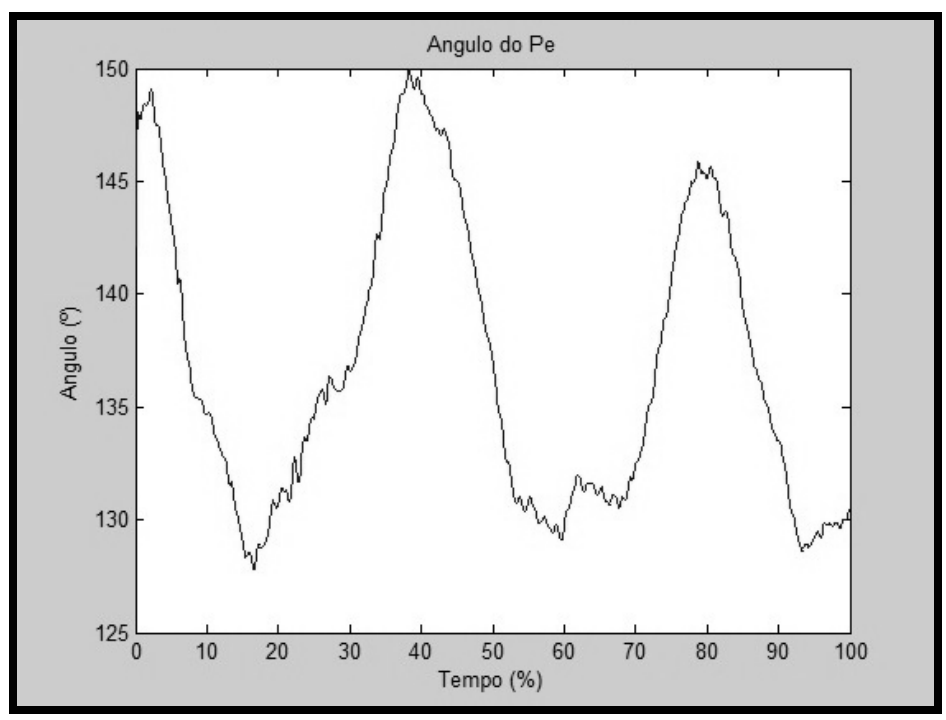

Gráfico 30- Movimento da articulação do tarso do animal V Monstra, durante as fases de balanço, apoio e propulsão. A diminuição na curva representa uma diminuição do ângulo articular e o aumento da curva indica um aumento do ângulo articular.

\subsubsection{ANIMAL VI WINNER}

Neste animal podemos observar no movimento da articulação escapuloumeral uma angulação máxima de $164^{\circ} \pm 7.85$ e angulação mínima de $117.2^{\circ} \pm 4.65$ durante a marcha. O gráfico 31 representa o comportamento dessa articulação durante a coleta. 


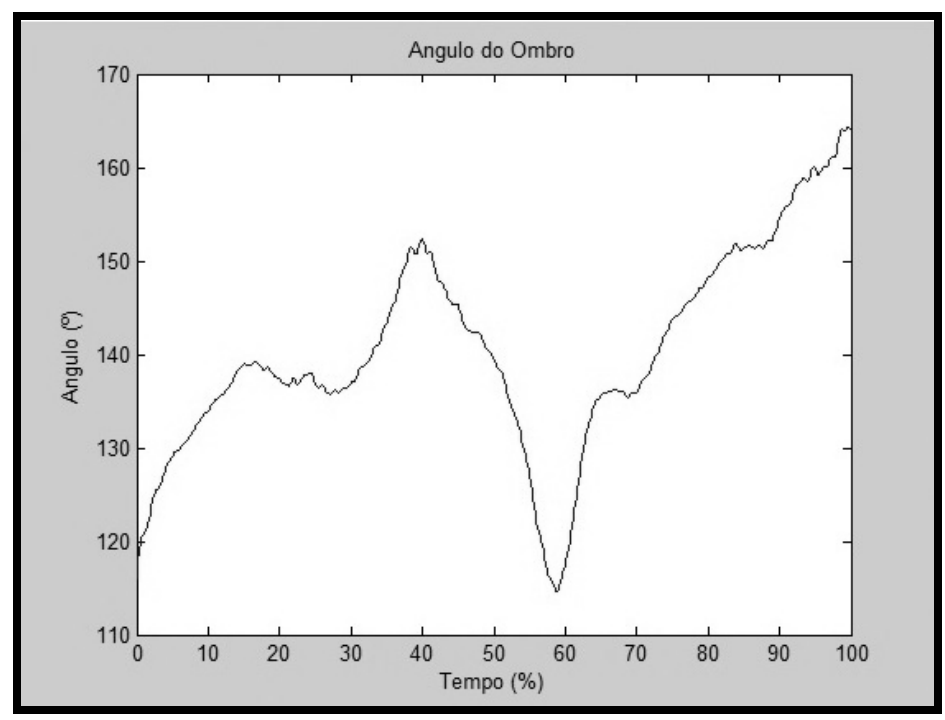

Gráfico 31- Movimento da articulação escapuloumeral do animal VI Winner, durante as fases de balanço, apoio e propulsão. A diminuição na curva representa uma diminuição do ângulo articular e o aumento da curva indica um aumento do ângulo articular.

$\mathrm{Na}$ articulação umeroradioulnar a angulação máxima de $166^{\circ} \pm 10.65$ e angulação mínima de $117.4^{\circ} \pm 3.50$ durante a marcha. O gráfico 31 representa o comportamento dessa articulação durante e coleta.

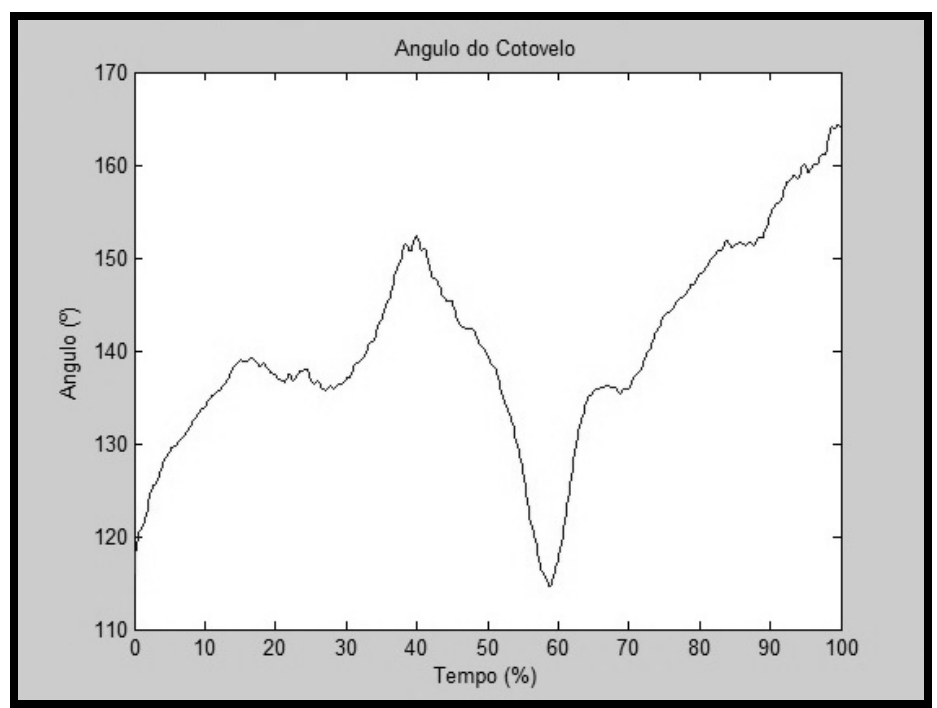

Gráfico 32- Movimento da articulação umeroradioulnar do animal VI Winner, durante as fases de balanço, apoio e propulsão. A diminuição na curva representa uma diminuição do ângulo articular e o aumento da curva indica um aumento do ângulo articular. 
$\mathrm{Na}$ articulação do carpo desse mesmo animal a angulação máxima de $164.4^{\circ} \pm 8.08 \mathrm{e}$ angulação mínima de $118.6^{\circ} \pm 4.72$ durante a marcha. $\mathrm{O}$ gráfico 33 representa o comportamento dessa articulação durante a coleta.

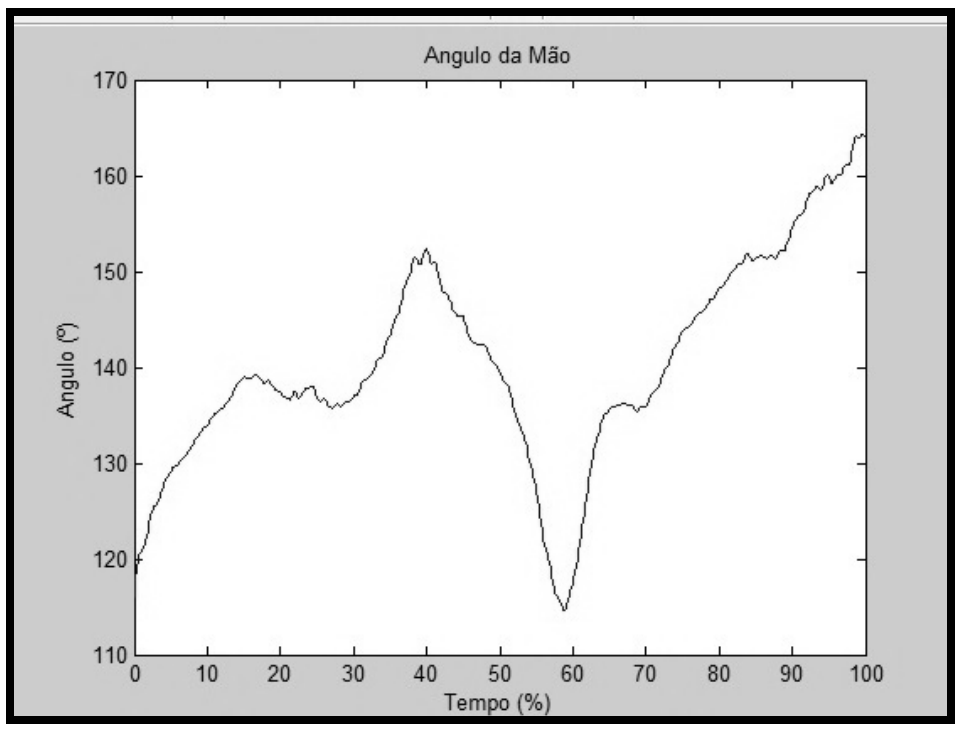

Gráfico 33- Movimento da articulação do carpo do animal VI Winner, durante as fases de balanço, apoio e propulsão. A diminuição na curva representa uma diminuição do ângulo articular e o aumento da curva indica um aumento do ângulo articular.

$\mathrm{Na}$ articulação coxofemoral a angulação máxima de $169^{\circ} \pm 2.34$ e angulação mínima de $119^{\circ} \pm 3.39$ durante a marcha. O gráfico 34 ilustra o comportamento dessa articulação durante a coleta.

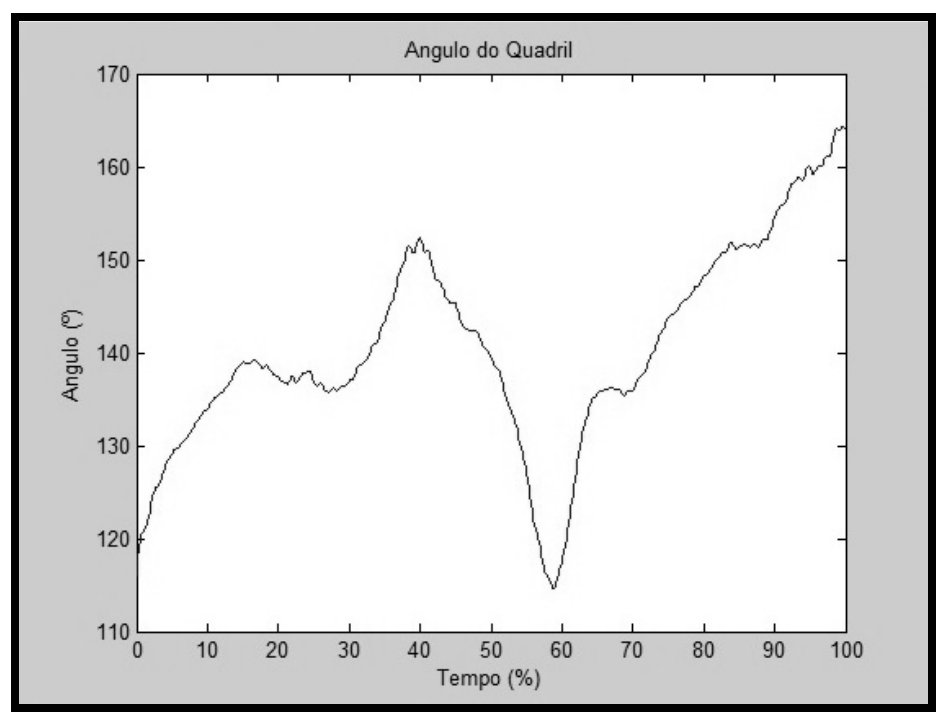

Gráfico 34- Movimento da articulação coxofemoral do animal VI Winner, durante as fases de balanço, apoio e propulsão. A diminuição na curva representa uma diminuição do ângulo articular e o aumento da curva indica um aumento do ângulo articular. 
$\mathrm{Na}$ articulação femortibiopatelar, a angulação máxima de $158.2^{\circ} \pm 8.40$ e angulação mínima de $114^{\circ} \pm 1.14$ durante a marcha. O gráfico 35 representa o comportamento dessa articulação durante a coleta.

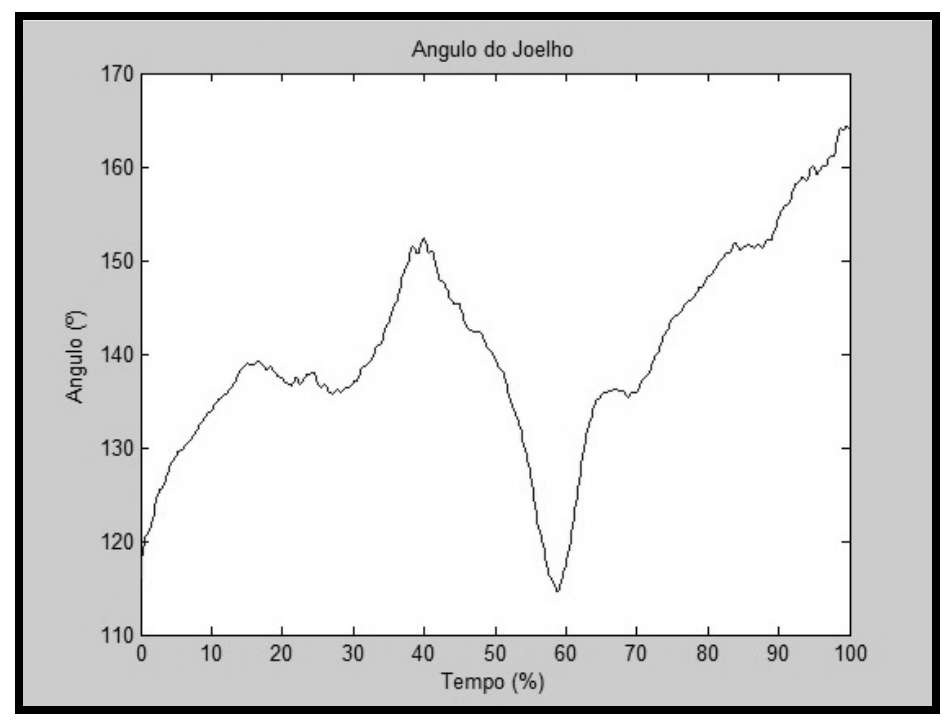

Gráfico 35 - Movimento da articulação femortibiopatelar do animal VI Winner, durante as fases de balanço, apoio e propulsão. A diminuição na curva representa uma diminuição do ângulo articular e o aumento da curva indica um aumento do ângulo articular.

Já na articulação do tarso, a angulação máxima de $167.4^{\circ} \pm 3.20$ e angulação mínima de $116.4^{\circ} \pm 5.31$ durante a marcha. O gráfico 36 ilustra o comportamento dessa articulação durante a marcha. 


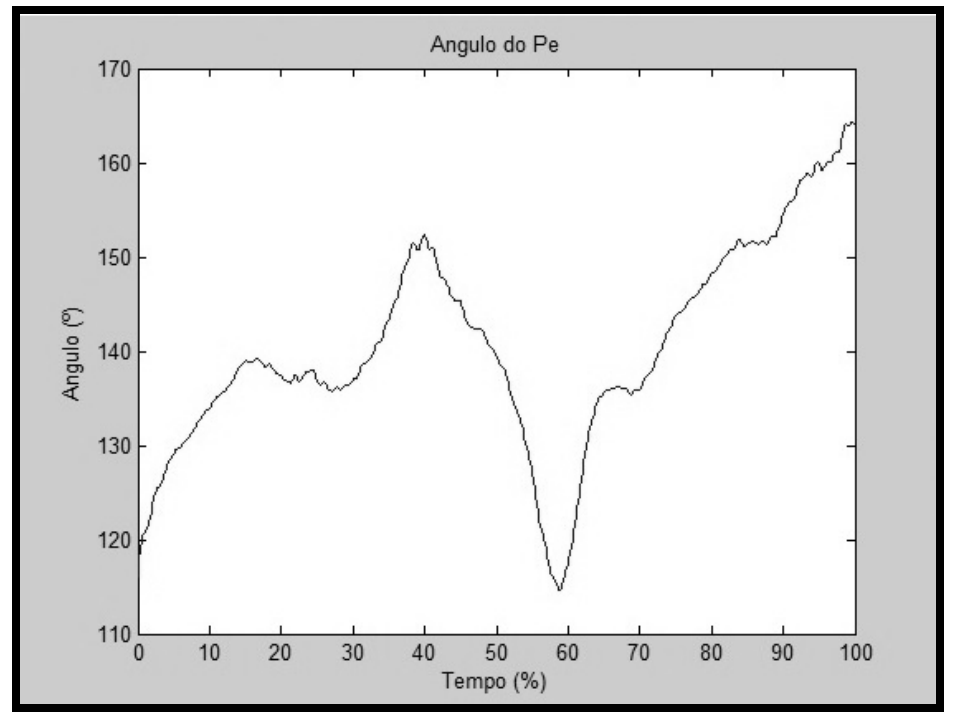

Gráfico 36 - Movimento da articulação do tarso do animal VI Winner, durante as fases de balanço, apoio e propulsão. A diminuição na curva representa uma diminuição do ângulo articular e o aumento da curva indica um aumento do ângulo articular.

A tabela abaixo ilustra os valores médios de flexão e extensão de cada articulação dos sei animais estudados. 
Tabela 3 - Valores dos ângulos articulares dos seis animais estudados

\begin{tabular}{|c|c|c|c|c|c|c|}
\hline & $\mathrm{BIZ}$ & GASPAR & LOLA & LUCK & MONSTRA & WINNER \\
\hline $\begin{array}{l}\text { Escapuloumeral } \\
\text { flexão }\end{array}$ & $119.2^{\circ}$ & $107.6^{\circ}$ & $123^{\circ}$ & $139.8^{\circ}$ & $127^{\circ}$ & $117.2^{\circ}$ \\
\hline $\begin{array}{l}\text { Escapuloumeral } \\
\text { extensão }\end{array}$ & $123.8^{\circ}$ & $136.6^{\circ}$ & $150.8^{\circ}$ & $179.4^{\circ}$ & $150^{\circ}$ & $164^{\circ}$ \\
\hline $\begin{array}{l}\text { Umeroradioulnar } \\
\text { flexão }\end{array}$ & $120.2^{\circ}$ & $106.6^{\circ}$ & $124^{\circ}$ & $140^{\circ}$ & $120^{\circ}$ & $117.4^{\circ}$ \\
\hline $\begin{array}{l}\text { Umeroradioulnar } \\
\text { extensão }\end{array}$ & $133^{\circ}$ & $136.4^{\circ}$ & $151^{\circ}$ & $179^{\circ}$ & $148^{\circ}$ & $166^{\circ}$ \\
\hline $\begin{array}{l}\text { Carpo } \\
\text { flexão }\end{array}$ & $120.6^{\circ}$ & $107^{\circ}$ & $124.6^{\circ}$ & $139.4^{\circ}$ & $126^{\circ}$ & $118.6^{\circ}$ \\
\hline $\begin{array}{l}\text { Carpo } \\
\text { extensão }\end{array}$ & $133.2^{\circ}$ & $136.4^{\circ}$ & $150.8^{\circ}$ & $179.4^{\circ}$ & $149^{\circ}$ & $164.4^{\circ}$ \\
\hline $\begin{array}{l}\text { Coxofemoral } \\
\text { flexão }\end{array}$ & $119^{\circ}$ & $108^{\circ}$ & $123.8^{\circ}$ & $140^{\circ}$ & $124^{\circ}$ & $119^{\circ}$ \\
\hline $\begin{array}{l}\text { Coxofemoral } \\
\text { extensão }\end{array}$ & $132.2^{\circ}$ & $136.8^{\circ}$ & $151^{\circ}$ & $179.8^{\circ}$ & $150^{\circ}$ & $169^{\circ}$ \\
\hline $\begin{array}{l}\text { Femortibiopatelar } \\
\text { flexão }\end{array}$ & $118.8^{\circ}$ & $108^{\circ}$ & $123.6^{\circ}$ & $179.4^{\circ}$ & $129^{\circ}$ & $114^{\circ}$ \\
\hline $\begin{array}{l}\text { Fermortibiopatelar } \\
\text { extensão }\end{array}$ & $133^{\circ}$ & $136.6^{\circ}$ & $151^{\circ}$ & $141^{\circ}$ & $152^{\circ}$ & $158.2^{\circ}$ \\
\hline $\begin{array}{l}\text { Tarso } \\
\text { flexão }\end{array}$ & $119^{\circ}$ & $108.2^{\circ}$ & $124.2^{\circ}$ & 139.8 & $127^{\circ}$ & $116.4^{\circ}$ \\
\hline $\begin{array}{l}\text { Tarso } \\
\text { extensão }\end{array}$ & $133^{\circ}$ & $136.8^{\circ}$ & $150.8^{\circ}$ & $180^{\circ}$ & $150^{\circ}$ & $176.4^{\circ}$ \\
\hline
\end{tabular}

Após a análise de cada animal, foi feita a média dos valores dos ângulos articulares dos seis animais estudados que estão descritos na tabela 4 . 
Tabela 4- Média dos valores dos ângulos articulares dos seis cães estudados.

\begin{tabular}{|c|c|c|c|c|}
\hline \multirow{2}{*}{$\begin{array}{l}\text { Variáveis } \\
\text { Escapuloumeral - flexão }\end{array}$} & \multirow{2}{*}{$\begin{array}{l}\text { Unidade } \\
\text { [graus] }\end{array}$} & \multirow{2}{*}{$\begin{array}{l}\text { Média } \\
121.10\end{array}$} & \multicolumn{2}{|c|}{ Desvio Padrão } \\
\hline & & & 11.78 & $p>0.10$ \\
\hline Escapuloumeral - extensão & [graus] & 150.40 & 19.39 & $p>0.10$ \\
\hline Umeroradioulnar - flexão & [graus] & 120.10 & 12.20 & $p>0.10$ \\
\hline Umeroradioulnar - extensão & [graus] & 149.50 & 19.78 & $p>0.10$ \\
\hline Carpo - flexão & [graus] & 122.60 & 11.45 & $p>0.10$ \\
\hline Carpo - extensão & [graus] & 149.90 & 19.35 & $p>0.10$ \\
\hline Coxofemoral - flexão & [graus] & 121.40 & 11.86 & $p>0.10$ \\
\hline Coxofemoral - extensão & [graus] & 150.50 & 20.17 & $p>0.10$ \\
\hline Femortibiopatelar - flexão & [graus] & 121.20 & 12.46 & $p>0.10$ \\
\hline Fermortibiopatelar - extensão & [graus] & 146.00 & 18.62 & $p>0.10$ \\
\hline Tarso - flexão & [graus] & 121.60 & 11.79 & $p>0.10$ \\
\hline Tarso - extensão & [graus] & 150.40 & 20.18 & $p>0.10$ \\
\hline
\end{tabular}

Para todas as análises dos ângulos articulares analisadas foram aceitas a hipótese de normalidade pelo método GraphPad, valor de $\mathrm{p}>0.10$.

\subsection{VARIAÇÕES DINÂMICAS}

Nos dados obtidos referentes a variações dinâmicas, foram analisados os picos da força de reação do membro pélvico em cada uma das seis tentativas válidas. O gráfico 37 ilustra o comportamento dessa força em cada um dos animais. 
Gráfico 37 - Pico de força de reação ao solo vertical do membro torácico dos seis animais estudados.

\section{Pico de FRS vertical mebro pélvico}

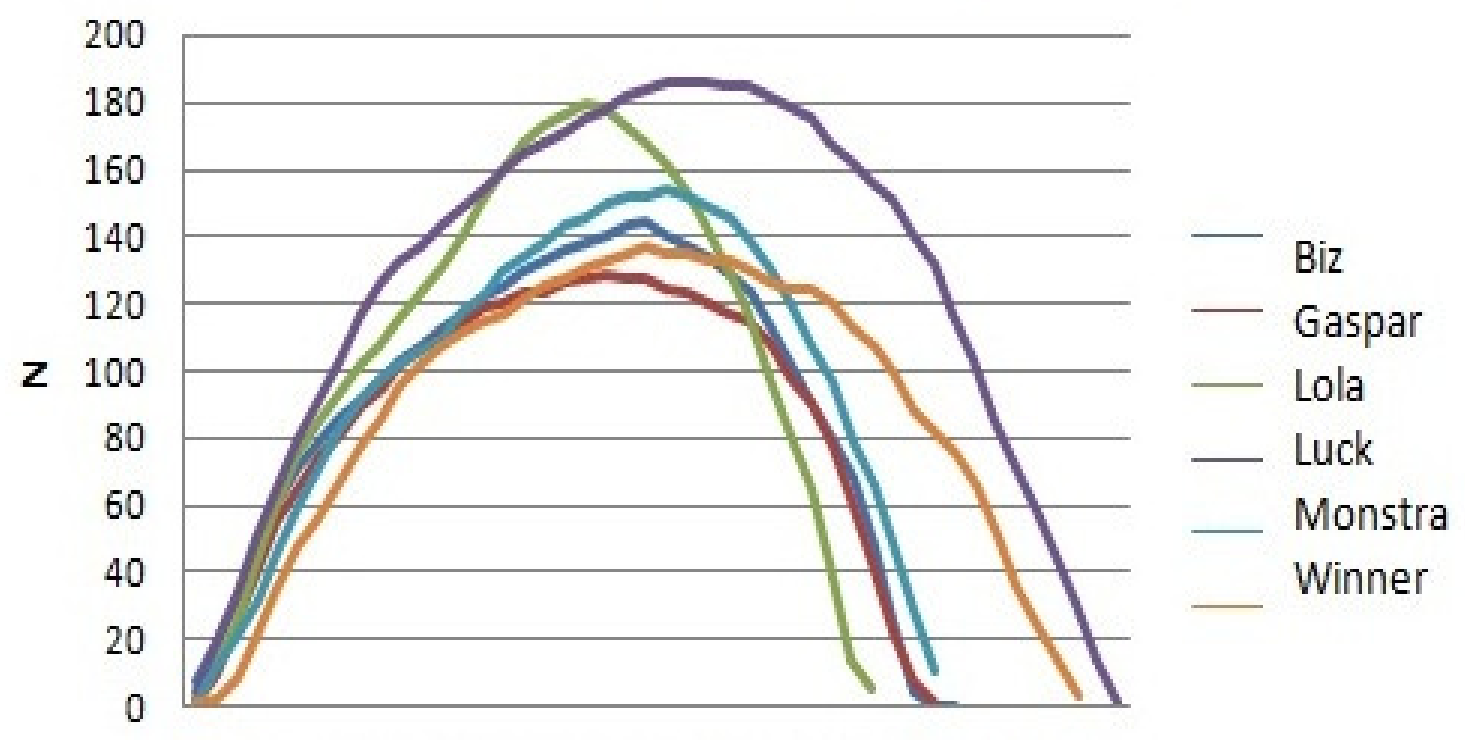

13579111315171921232527293133353739414345

Os picos verticais de força de reação solo de cada um dos animais estão expressos na tabela 5 .

Tabela 5 - Média dos valores dos picos de força de reação ao solo de cada um dos animais.

\begin{tabular}{llll}
\hline Animal & Média & \multicolumn{2}{l}{ Desvio Padrão } \\
\hline Biz & 141 & 5.76 & $\cdot p>0.10$ \\
Gaspar & 128 & 8.32 & $\ldots p>0.10$ \\
Lola & 180 & 4.97 & $p>0.10$ \\
Luck & 183 & 2.49 & $p>0.10$ \\
Monstra & 150 & 5.92 & $p>0.10$ \\
Winner & 135 & 6.25 & $p>0.10$ \\
\hline
\end{tabular}

Para todas as análises biométricas analisadas foram aceitas a hipótese de normalidade pelo método GraphPad, valor de $\mathrm{p}>0.10$. 


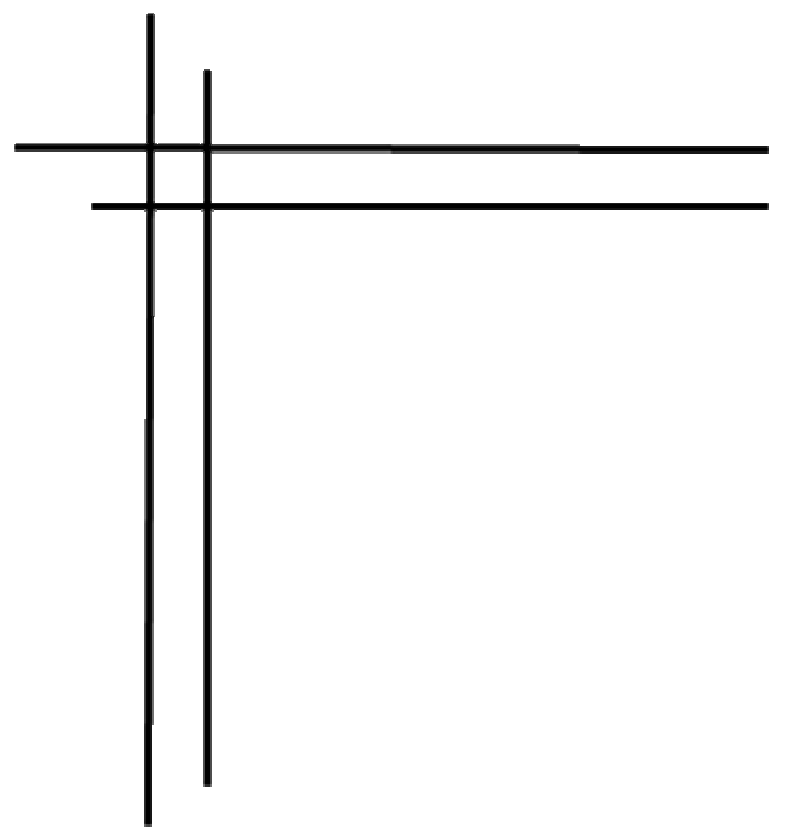

Discussãa 


\section{DISCUSSÃO}

A distrofia muscular de Duchenne se manifesta por um defeito no gene da distrofina, proteína associada ao sarcolema dos músculos lisos, cardíacos e esquelético que ajuda a manter a integridade da membrana durante o processo de contração e relaxamento muscular. (PALMIERI et al., 1996; BERGMAN et al., 2002). Esses indivíduos afetados pela distrofia apresentam alterações significantes no organismo quando comparados com a população normal (PALMIERI et al., 1996)

A inexistência de um tratamento definitivo para esta doença tem incentivado pesquisas que em geral abordam terapias celulares, genéticas e medicamentosas com modelos animais, principalmente o camundongo mdx. De acordo com McLoon (2008) deve se estimular a investigação de terapias complementares e de suporte da doença para aumentar a qualidade de vida dos pacientes.

O modelo canino GRMD é o modelo animal mais similar a DMD humana. Por ser geneticamente homólogo, compartilha seu quadro de miopatia severa e desenvolvimento clínico letal (COOPER et al., 1988; VALENTINE et al., 1990). Além das alterações musculares serem as mais próximas daquelas encontradas em humanos, cães adultos do modelo GRMD apresentam peso corporal relativamente semelhante ao de meninos afetados, o que possibilita um melhor monitoramento da fraqueza muscular da patologia e estratégias de tratamento durante experimentos (GAIAD, 2006).

- A avaliação visual da marcha do animal é utilizada para diagnosticar e monitorar a progressão de uma doença, porém é uma analise subjetiva e qualitativa (HARRIS, 1994). Ela é usada para caracterizar o movimento articular em várias espécies e raças, e comparar o comportamento articular de cães com afecções músculo esqueléticos e cães saudáveis (MARSOLAIS, 2003).

Nesse estudo objetivamos estabelecer dados das variáveis da marcha de cães da raça Golden Retriever afetados pela distrofia muscular a fim de contribuir para a compreensão e padronização da locomoção desses animais além de fortalecer as ferramentas de avaliação clínica deste modelo. 
Publicações em avaliações animais vêm crescendo da mesma forma que nas avaliações em humanos. Através de um estudo cinemático, Coulbome (2005) comparou as raças Greyhoun e Labrador Retriever onde concluiu que as diferenças na mecânica coxal são evidentes, a amplitude de movimento articular de membros pélvicos do Greyhound foi bem maior que a do Labrador Retriever deixando claro que fatores corporais específicos da raça influenciam na movimentação do animal.

Suwankong et. al. (2007) através de resultados obtidos com uma plataforma de força, mostraram prejuízo da força propulsiva dos membros pélvicos de animais no póscirurgico de descompressão da estenose lombosacral degenerativa, enquanto os proprietários dos mesmo através de observação os avaliaram como tendo sua função totalmente estabelecida.

Em outro estudo na determinação da componente vertical da força de reação do solo atuante nos membros de bovinos jovens da raça Girolanda nas condições estática e dinâmica, Rodrigues et. al. (2009), relataram que no caso das FRS na condição dinâmica os resultados mostram que a configuração das curvas registradas se assemelha às encontradas em literaturas de referência para marcha normal de humanos e que a FRS máxima encontrada corresponde, em média, a mais de $50 \%$ do peso do animal. Observaram também que na condição dinâmica, as FRS exercidas sobre os membros posteriores podem se alcançar valores duas vezes superiores aos observados na condição estática.

Em um estudo comparativo de resultados de avaliação qualitativa e quantitativa de animais submetidos à osteotomia da tíbia corrigidos por fixadores externos, Quinn et al. (2007) relataram que os dois tipos de avaliação tiveram concordância somente quando o grau de claudicação era severo. A avaliação qualitativa não foi capaz de detectar claudicações de grau leve.

Silva (2005) através de um estudo cinemático analisou a marcha de sete cães da raça Golden Retriever clinicamente normais. Pode concluir que esse método de estudo provou ser um consistente método de avaliação do movimento durante a marcha e os dados obtidos podem ser utilizados na comparação em avaliações de marcha para outros estudos e base de normalidade quando comparados a evolução de tratamentos de cães com afecções musculoesqueléticas. 
Podemos observar então a sensibilidade da avaliação biomecânica, que além de fornecer dados quantitativos para comparação de progressão de uma doença degenerativa ou diferenças pré e pós-tratamento, também possibilitam ao profissional entender as perdas de função e alterações decorrentes de terapias e ou doenças. (MACHADO, 2009).

Por a avaliação biomecânica animal ser um assunto recente, poucos estudos foram encontrados com o modelo experimental canino GRMD. Em estudo recente Marsh et. al., 2010 objetivou quantificar a cinemática bi-dimensional na articulação do joelho e tornozelo de seis cães do modelo GRMD, comparados com seis cães Golden Retriever clinicamente normais (controles). Resultaram que os cães GRMD andaram significativamente mais lento que o cão controle e na articulação do joelho, os GRMD andaram com o joelho relativamente mais estendido em comparação aos controles. $\mathrm{Na}$ articulação do jarrete, o modelo GRMD exibiu menos amplitude de movimento e andou com a articulação relativamente menos flexionada comparados aos controles.

Machado (2009) objetivou em seu estudo, elucidar o papel da fisioterapia motora na deposição de colágeno muscular, bem como em alguns parâmetros cinemáticos e dinâmicos da marcha do modelo GRMD. Em seus resultados mostraram que os animais tratados com a fisioterapia apresentaram diminuição da flexibilidade e menor regeneração do tecido muscular em comparação aos animais não tratados. Relatou também que funcionalmente, a fraqueza muscular dos animais distróficos reflete em uma marcha lenta, com característica de sobrecarga e dificuldade de avançar o corpo.

Em outro estudo utilizando o modele canino GRMD, investiga a viabilidade do uso do acelerômetro como medida quantitativa da marcha de animais distróficos. Esta ferramenta difere da utilizada em nossa pesquisa, uma vez que o acelerômetro é acoplado ao corpo do animal. Os dados apresentados pelos autores fornecem importantes características da marcha do animal distrófico e concluíram que a acelerometria representa uma ferramenta útil para avaliar a locomoção durante testes pré e pós-clinicos

. Em nosso estudo, os dados da pesquisa foram realizados no Laboratório de Biomecânica da Escola de Educação Física e Esportes da Universidade de São Paulo. 
Os seis animais avaliados passaram por um processo de adaptação ao espaço do laboratório antes da coleta, com o objetivo de os animais se sentirem familiarizados ao ambiente de coleta e pudesse realizar a marcha o mais próximo possível do usual sem interferência no resultado final.

A análise feita neste estudo utilizou um espaço bidimensional, porém outros estudos da marcha animal utilizaram espaços tridimensionais, Hottinger (1996) e Bennet (1995). Nielsen (2003) realizou análises de marcha bidimensional e tridimensional de membros anteriores de cães saudáveis e afirmou que existem diferenças notáveis entre essas análises, como por exemplo, as curvas excursão articular e a amplitude de movimento.

A colocação das marcas flexivas é uma possível fonte de erro, causada pelo deslocamento da pele do animal podendo movimentar as marcas e levar à possíveis erros. Em estudo avaliando os efeitos deste deslocamento em cavalos Van Den Bogert e Weeren (1990) concluíram que na articulação escapuloumeral o deslocamento ocorreu 1 a $4 \mathrm{~cm}$ e na articulação coxofemoral o deslocamento médio foi de 13 a $17 \mathrm{~cm}$, concluindo que este deslocamento é de importância considerável na interpretação No entanto a anatomia e a biomecânica do cavalo difere-se da canina, não esclarecendo como esses achados podem ser aplicados a esse estudo.

Os dados morfométricos analisados não demonstraram diferenças físicas significativas entre os cães estudados. Os dados obtidos foram braço: $16,69 \mathrm{~cm}$; antebraço 17,12cm; carpo 5,16cm; coxa 18,91cm; perna 19,03cm; tarso $10,98 \mathrm{~cm}$; tórax $67.54 \mathrm{~cm}$; altura $52,14 \mathrm{~cm}$; e peso 20,44kg. Esses dados corroboram com os resultados de Silva (2006), que também não encontrou diferenças significativas entre os sete cães da raça Golden Retriever clinicamente normais analisados.

Visualmente falando, a forma de deambulação de cada animal é única, e notouse também que havia cães mais resistentes que outros, devido à patologia, o que poderia alterar de alguma forma a variável estudada.

Os resultados do comportamento das articulações estudadas indicam uma variação maior de flexão e extensão das articulações do membro pélvico. Em nosso estudo a angulação foi: coxofemoral (flexão $122.08^{\circ}$ e extensão $153.96^{\circ}$ ), femortibiopatelar (flexão $121.2^{\circ}$ e extensão $151.64^{\circ}$ ), tarso (flexão $121.48^{\circ}$ e extensão 
$153.44^{\circ}$ ). Machado (2009), em seu estudo sugere maior comprometimento do mesmo (coxofemoral e tarso) em seu estudo com cães do mesmo modelo; uma vez que fez duas avaliações; aos cinco e aos nove meses de vida.

Marsh (2010), em seu estudo pioneiro comparou e mediu o comportamento da articulação femortibiopatelar e tarso de cães GRMD e cães Golden Retriever saudáveis. Seus resultados indicaram que os cães GRMD andaram mais lentos em relação aos controles; na articulação femortibiopatelar ambos os grupos exibiram uma amplitude semelhante, mas comparados aos controles dos cães GRMD andou com essa articulação relativamente mais extensa. Em nosso estudo podemos observar que a articulação fermortibiopatelar também foi a que teve um grau de extensão maior se comparada a outras articulações. Em relação à articulação do tarso March et. al (2010) os cães GRMD exibiram uma menor amplitude de movimento comparadas aos cães controles.

Bensacon et al. (2004) mostraram em seus estudos que a força de reação ao solo vertical é maior nos membros torácicos que nos membros pélvicos, porém em nosso estudo foi possível calcular a força do membro torácico, que teve uma variável significativa em relação aos animais estudados

Os resultados aqui obtidos são importantes para implantação de protocolos e avaliação clinica para análise do movimento de cães GRMD. 


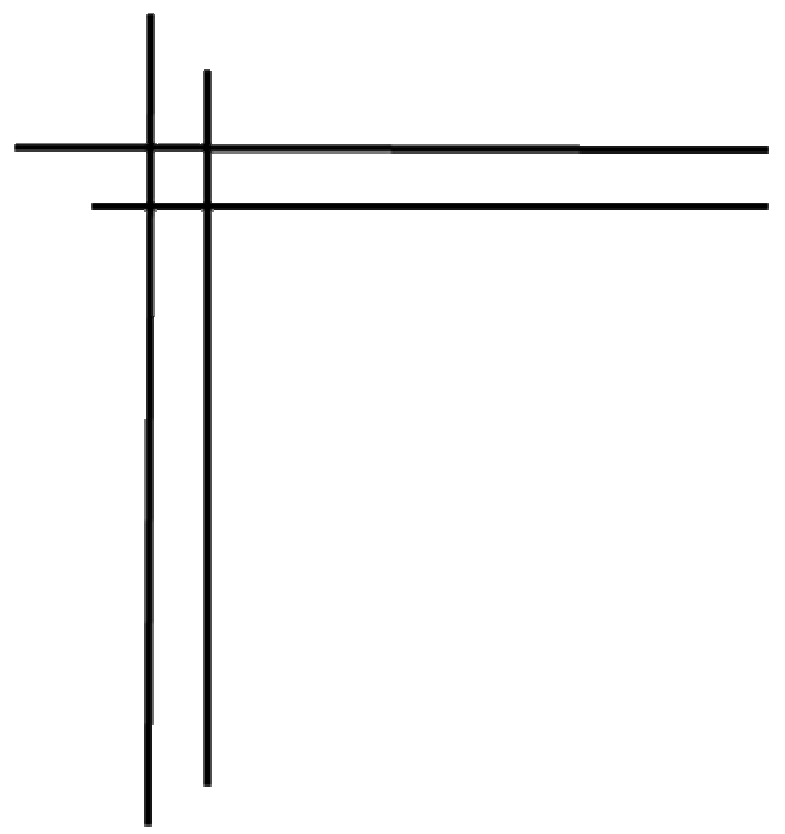

Canclusãa 


\section{Conclusões}

- Os animais distróficos têm uma marcha lenta, com dificuldades de avançar os membros durante a marcha.

- A forma de deambulação é diferente em cada um dos animais

- A articulação femortibiopatelar foi a que teve um grau de amplitude maior em relação as outras articulações

- Os picos de flexão e extensão articular variam de acordo com cada articulação.

- Os picos de flexão e extensão variam mais no membro pélvico do que no membro torácico.

- Os resultados obtidos podem ser úteis em avaliações pré-clinicas utilizando o modelo canino GRMD. 


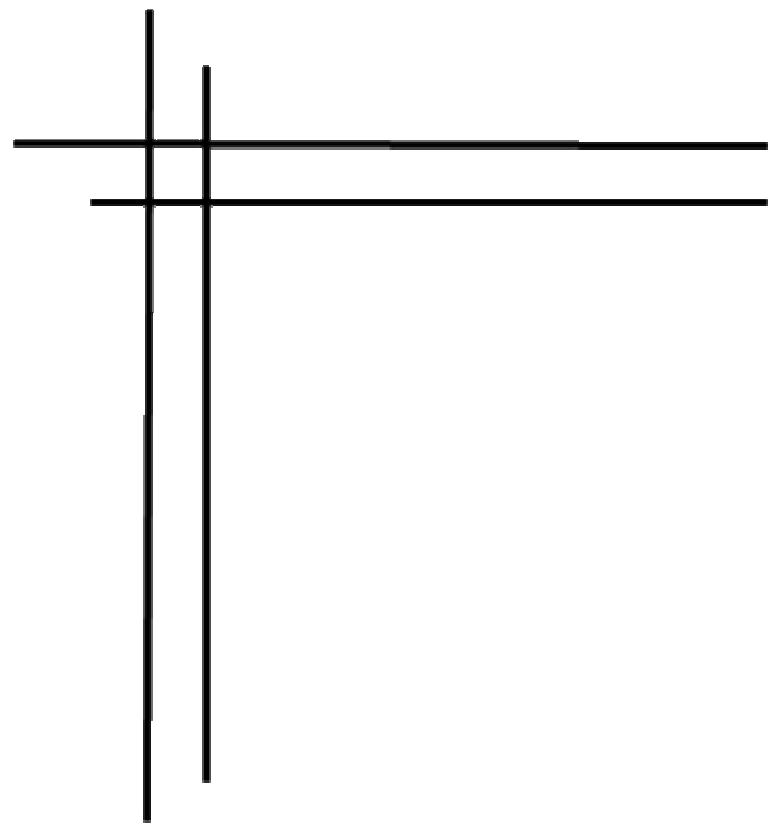

Referencias 


\section{REFERÊNCIAS}

ALLEN, K.; DECAMP, C. E.; BRADENT, T. D.; BAHNS, M. Kinematic gait analysis of the trot in healthy mixed breed dogs. Veterinary and Comparative Orthopedics and Traumatology, v. 7, p. 148-153, 1994.

AMADIO, A. C. Fundamentos biomecânicos para análise do movimento humano, 1996, 86 f. Dissertação (Mestre em Educação Física) - Escola de Educação Física e Esporte da Universidade de São Paulo, 1996.

AMADIO, A. C.; COSTA, P. H. L.; SACCO, I. C. N.; SERRÃO, J. C.; ARAÚJO, R. C. MOCHIZUKI, L.; DUARTE, M. Introdução à análise do movimento humano descrição e aplicação dos métodos biomecânicos de medição. Revista Brasileira de Fisioterapia, v. 3, n. 2, p. 41-54, 1999.

AMBROSIO, C. E.; FADEL, L.; GAIAD, T. P.; MARTINS, D. S.; ARAÚJO, K. P.; ZUCCONI, E.; BROLIO, M. P.; GIGLIO, R. F.; MORINI, A. C.; JAZEDJE, T.;

FROES, T. R.; FEITOSA, M. L.; VALADARES, M. C.; BELTRÂO-BRAGA, P. C.; MEIRELLES, F. V.; MIGLINO, M. A. Identification of three distinguishable phenotypes in golden retriever muscular dystrophy. Genetics and Molecular Research, v. 8, n. 2, p. 389-396, 2009.

ANDERSON, G. I.; HEARN, T.; TAVIS, C. Force plate gait analysis in normal and dysplastic dogs before and after total hip replacement surgery: an experimental study. Veterinary Surgery, v. 17, n. 1, p. 27, 1998.

BANKS, G. B.; CHAMBERLAIN, J. S. The value of mammalian models for Duchenne Muscular Dystrophy in developing therapeutic strategies. In: KRAUSS, R. S. Current Topics in Developmental Biology. Burlington: Academic Press, 2008. v. 84, p. 431453.

BARTHÉLEMY, I.; BARREY, E.; THIBAUD, J. L.; URIARTE, A.; VOIT,T.; BLOT, S.; HOGREL, J. Y. Gait analysis using accelerometry in dystrophin-deficient dogs. Neuromuscular Disorders, v. 19, n. 11, p.788-796, 2009.

BAROHN, R. J.; LEVINE, E. J.; OLSON, J. O.; MENDELL, J. R. Gastric hypomotility in Duchenne's Muscular Dystrophy. New England Journal of Medicine, v. 319, n. 1, p. 15-18, 1988.

BENNET, R. L.; DECAMP, C. E.; FLO, G.; HAUPTMAN, J. G.; STAJICH, M. Kinematic gait analysis in dogs with hip dysplasia. American Journal Veterinary Research, v. 57, n. 7, p. 996-971, 1996.

BERGMAN, R. L.; INZANA, K. C.; MONROE, W. E.; SHELL, L. G.; LUI, L. A.; ENGVALL, E.; SHELTON, G. D. Dystrophin-deficient muscular dystrophy in a 
Labrador retriever. Journal of the American Animal Hospital Association, v. 38, n. 3, p. 255-261, 2002.

BERTRAN, J. E.; LEE, D. V.; CASE, H. N.; TODHNTER, R. J. Comparison of the trotting gaits of Labrador retriver and greyhound. American Journal Veterinary Research, v. 6, n. 7, p. 832-838, 2000.

BERTRAN, J. E.; TODHUNTER, R. J.; FOELS, W. S.; WILLIAMS, A. J.; LUST, G. Multiple force platform analysis of the canine trot: a new approach to assessing basic characteristics of locomotion. Veterinary and Comparative Orthopedics and Traumatology, v. 10, p. 160-169, 1997.

BESANCON, M. F.; CONZEMIUS, M. G.; DERRICK, T. R.; RITTER, M. J. Comparison of vertical forces in normal greyhounds between force platform and pressure walkway measurement sustems. Veterinary and Comparative Orthopedics and Traumatology, v. 16, n. 3, p. 153-157, 2003.

BOMBONATO, P. P.; MORAES, V. V.; OLIVEIRA, M. A. R. G. Biomecânica canina. In: MIKAIL, S.; PEDRO, C. R. Fisioterapia Veterinária. São Paulo: Manole, 2005. p.13-17.

BRAGA, I. Fisioterapia na medicina veterinária. Revista Fisio \& Terapia, v. 2, n. 12, p. 19, 1999.

BRIGUET, A.; COURDIER-FRUH, I.; FOSTER, M.; MEIER, T.; MAGVAR, J. P. Histological parameters for the quantitative assessment of muscular dystrophy in the mdx-mouse. Neuromuscular Disorders, v. 14, p. 675-682, 2004.

BUDSBERG, S. C.; VERSTRAETE, M. C.; SOUTAS-LITTLE, R. W. Force plate analysis of the walking gait in healthy dogs. American Journal of Veterinary Reserch, v. 48, n. 6, p. 915-918, 1987.

CHILDERS, M. K.; OKAMURA, C. S.; BOGAN, D. J.; BOGAN, J. R.; PETROSKI, G. F.; MCDONALD, K.; KORNEGAY, J. N. Eccentric contraction injury in dystrophic canine muscle. Archives of Physical Medicine and Rehabilitation, v. 83, p. 15721578, 2002.

CLAYTON, H. M. Advances in motion analysis. Veterinary Clinics North American Equine Practice, v. 7, n. 2, p. 365-382, 1991.

COLLINS, C. A.; MORGAN, J. E. Duchenne's muscular dystrophy: animal models used to investigate pathogenesis and develop therapeutic strategies. International Journal of Experimental Pathology, v. 84, n. 4, p. 165-172, 2003.

COOPER, B. J.; WINAND, N. J.; STEDMAN, H.; VALENTINE, B. A.; HOFFMAN, E. P.; KUNKELL, L. M.; SCOOT, M.; FISCHBECK, K. H.; KORNEGAY, J. N.; AVERY, R. J.; WILLIAMS, J. R.; SCHMICKEL, R. D.; SYLVESTRER, J. E. Thei 
homologue of the Duchenne lócus in defective in $\mathrm{x}$ - linked muscular dustrophy of dogs. Nature, v. 334, p. 154-156, 1988.

COROMANO, F. A. Características do portador de distrofia muscular de Duchenne: revisão. Arquivos de Ciências da Saúde da UNIPAR, v. 3, n. 3, p. 211-218, 1999.

DAVID, A. C. Aspectos Biomecânicos do Andar em Crianças: Cinemática e Cinética. Dissertação (Doutorado em Ciência do Movimento Humano) - Universidade Federal de Santa Maria, Rio Grande do Sul, 2000.

DECAMP, C. E.; RIGGS, C. M.; OLIVIER, B.; HAUPTMAN, J. G.; HOTTINGER, H. A.; Dystrophy in developing therapeutic strategies. In: EMERY, A. E. H. Current Topics in Developmental Biology. 2 ed. Orford: Oxford University Press, 1997.

ENOKA, R. M. Bases neuromecânicas da cinesiologia. 2. ed. São Paulo: Manole, 2000. p. 3- 216.

FUNG, Y. C. Biomechanics: motions, flow, stress and growth. New York: Springer Verlag, 1990. p. 7.

ERAZO-TORRICELLI, R. Actualización em distrofinas musculares. Revista de Neurologia, v.39, p.860-871,2004.

FANCHON, L.; VALETTE, J. P.; SANAA, M.; GRANDJEAN, D. The measurement of ground reaction force in dogs trotting on a treadmill. Veterinary and Comparative Orthopedics and Traumatology, v. 19, n. 1, p. 86-89, 2006.

GAIAD, T. P. Influência da fisioterapia na função motora e histopatologia da fibra muscular esquelética no modelo Golden Retriever Muscular Dystrophy (GRMD), 2006; 98f. Dissertação (Mestrado de Ciências) - Faculdade de Medicina Veterinária e Zootecnia da Universidade de São Paulo, São Paulo, 2005.

GAIAD, T. P.; MIGLINO, M. A.; ZATZ, M.; HAMLETT, W. C.; AMBROSIO, C. E. Effect of physical therapy on joint range of motion and muscle collagen deposition in the golden retriever muscular dystrophy (GRMD) model. Revista Brasileira Fisioterapia, v.13, n. 3, p. 244-251, 2009.

GILLETTE, R. L., ANGLE, T. C. Recent developments in canine locomotor analysis. The Veterinary Journal, v.178, n. 2, p. 165-176, 2008.

GRANDO, A. P.; MARIANA, A. N. B.; MIGLINO, M. A.; STERMAN, F. A.; ZATZ, M.; KANAYAMA, L.; FEITOSA, M. L. T.; MARTINS, D. S.; MORINI, A. M.; SANTOS, J. P. A.; FADEL, L.; ALVES, F. R.; AMBRÓSIO, C. E. Ultra-sonografia abdominal e pélvica em cães da raça golden retriever sadios, portadores e afetados pela distrofia muscular progressiva. Ciência Rural, v. 39, n. 1, p. 123-128, 2009. 
GUO, Z. W.; WANG, G. Z.; LIU, Y. B.; DING, H.; LIU, L. J.; DING, H. S. A gait analysis system based on digital video and digital image processing. Space Medical Enginier, v. 15, n. 2, p. 122-126, 2002.

HACK, A. A.; GROH, M. E.; MCNALLY, E. M. Sarcoglycans in muscular dystrophy. Microscopy Research and Techique, v. 48, n. 3-4, p. 167-168, 2000.

HALL, S. J. Biomecânica básica. 3. ed. Rio de Janeiro: Guanabara Koogan, 2000.

HARRIS, G. F.; WERSTSH, J. J. Procedures for gait analysis. Archive of Physical Medicine Rehabilitation, v. 75, n. 2, p. 216-225, 1994.

HOTTINGER, H. A.; DECAMP, C. E. N.; OLIVIER, B.; HAUPTMAN, J. G.; SOUTAS-LITTLE, R. Noninvasive kinematic analysis of the walk in healthy large breeds dogs, American Journal Veterinary Research, v. 57, n. 3, p. 38-338, 1996.

HOWELL, J. M.; FLETCHER, S.; KAKULAS, B. A.; O'HARA, M.; LOCHMULLER, H.; KARPATI, G. Use of the dog model for Duchenne muscular dystrophy in gene therapy trials. Neuromuscular Disorders, v. 7, n. 5, p. 325-328, 1997.

JORDE, L. B. Genética médica. Rio de Janeiro: Elsevier, 2004. p. 111-113.

KEMPER, A. R.; WAKE, M. A. Duchenne muscular dystrophy: issues in expanding newborn screening. Current Opinion in Pediatrics, v. 19, n. 6, 2007.

MACHADO, T. P. G. Golden Muscular Dystrophy (GRMD) como modelo morfofuncional da reparação tecidual na Distrofia Muscular de Duchenne, 2009; 104 f. Tese (Doutorado de Ciências) - Faculdade de Medicina Veterinária e Zootecnia da Universidade de São Paulo, São Paulo, 2009.

MANN, R. W; ANTONSON, E. K. Gait analysis: precise, rapid, automatic, 3D position and orientation Kinematics and dynamics. Bulletion of the Hospital for Joint Diseases Orthopedic institute, v. 43, n. 2, p.137-146, 1983.

MARQUES, A. Manual de goniometria. 2. ed. São Paulo: Manole, 2003. p.1-8.

MARQUES, M. J. Structural biology of the dystrophin-deficient muscle fiber. Brazilian Journal of Morphology and Science, v. 21, n. 3, p. 145-152, 2004.

MARSOLAIS, G. S.; M. C. LEAN, S.; DERRICK, T.; CONZEMIUS, M. G.; Kinematic analysis of the hind limb during swimming and walking in healthy dogs and dogs with surgically corrected cranial cruciate ligament rupture. Journal American Veterinary Medical Association, v. 222, n. 6, p.739-743, 2003.

MATIAS, R.; GAMBOA, H. Avaliação do movimento e função humana: análise cinemática tridimensional e eletromiografia. FisiOnline. v. 1, n. 3, p.38-51, 2005. 
McGINLEY, J. L.; BAKER, R.; WOLFE, R.; MORRIS, M. E. The reliability of three dimensional kinematic gait measurements: a systematic review. Gait \& Posture, v. 29, n. 3, p. 360-369, 2006.

McKERRELL, R. E. Miopatias caninas e felinas. In: DUNN, J. K. Tratado de medicina de pequenos animais. São Paulo: Roca, 2001. p. 690-713.

MEIJER, O. G. Making things: na introduction to the history of movement science. In: LATASH, M. L.; ZATSIORSKY, V. N. M. Classics in movement science. USA: Human Kinects, 2001. p. 11- 12.

MIYATAKE, M.; MIIKE, T.; ZHAO, J.; YOSHIOKA, K.; UNCHINO, M.; USUKU, G. Possible systemic smooth muscle layer dysfunction due to a deficiency of dystrophin in Duchenne muscular dystrophy. Journal of the Neurological Sciences, v. 93, n. 1, p. 11-17, 1989.

MORIUCHI, T.; FUJII, Y.; KAGAWA, N.; HIZAWA, K. Autopsy on the heart, liver, kidney and brain in Duchenne muscular dystrophy. The Tokushima Journal of Experimental Medicine, v. 38, n. 1-2, p. 5-13, 1991.

NGUYEN, F.; CHEREL, Y.; GUIGAND, L.; GOUBAULT, L.I; WYERS, M. Muscles lesions associated with dystrophin deficiency in neonatal golden retriever puppies. Journal of Comparative Pathology, v. 126, n. 2-3, p. 100-108, 2002.

NICHOLS, P. L.; LYMN, R. W.; DRISCOLL, P. P.; CLEARFIELD, C. Gene therapy in duchenne muscular dystrophy. Brain and Development, v. 18, n. 5, p. 357-361, 1994.

NIELSEN, C.; STOVER, S. M.; SCHULZ, K. S.; HUBBRD, M.; HAWKINS, D. A. Two dimensional link segment model ofthe forelimb of dogs at a walk. American Journal Veterinary Research, v. 64, n. 5, p. 609-617, 2003.

OFF, W.; MATIS, U. Gait analysis in dogs. Tieraztliche Praxis, v. 25, n. 1, p. 8-14, 1997.

PALIMERI, G. M.; BERTORINI, T. E.; GRIFFIN, J. W.; IGARASHI, M.; KARAS, J. G. Assessment of Wole body composition with dual energy X-ray absorptiometry in Duchenne muscular dystrophy: correlation of lean body mass with muscle function. Muscle Nerve, v. 19, n. 6, p. 777-779, 1996.

PICON, A. P. Estudo biomecânico do ballet clássico: influência da sapatilha e do andamento musical no SAUTÉ em primeira posição. Dissertação (Mestre em Educação Física). Escola de Educação Física e Esporte da Universidade de São Paulo, São Paulo, 2004.

POY, N. S. J.; DECAMP, C.; BENNETT, R. L.; HAUPTMAN, J. G. Additional kinematic variables to describe differences in the trot between clinically normal dogs 
and dogs with hip dysplasia. American Journal Veterinary Research, v. 61, n. 8, p. 974-97, 2000.

QUINN, M. M.; KEULER, N.; LU, Y.; FARIA, M. L. E.; MUIR, P.; MARKEL, M. D. Evaluation of agreement between numerical rating scales, visual analogue scoring scales and force plate gait analysis in dogs. Veterinary Surgery, v. 36, n. 4, p. 360-367, 2007.

RODRIGUES, L. B.; LAS CASAS, E. B.; FALEIROS, R. R.; MANEZEL, H. J. Medição das forças de reação do solo em bovinos jovens nas situações de caminhada e de parada utilizando a plataforma de força. Revista Brasileira de Biomecânica, v. 10, p. 18, 2009.

RUMPH, P. F.; KINCAID, S. A.; BAIRD, D. K.; KAMMERMANN, B. S.; VISCO, D. M.; GOETZE, L. F. Vertical ground reaction force distribution during experimentally induced acute synovitis in dogs. American Journal of Veterinary Research, v. 54, n. 3, p. 365-369, 1994.

SAHRMANN, S. Concepts and principles of movement. In: SAHRMANN, S. Diagnosis \& treatment of movement impairment syndromes. EUA: Mosby, 2000. p.9-49.

SAMIEI, H. V. Genetic surgery for muscular dystrophy in golden retrievers. Genome News Network, June, 2000. Disponivel em:

http://www.genomenewsnetwork.org/articles/06_00/muscular_dystrophy. Acesso em 07 set. 2009.

SCHATZBERG, S. J.; SHELTON, D. G. Newly indentified neuromuscular disorders. The Veterinary Clinics of North America Small Animal Practice, v. 34, n. 6, p. 1497-1524, 2004.

SHELTON, G. D. Neuromuscular disorders. In: BIRCHARD, S. J.; SHERDING, R. G. Saunders manual of small animal practice. Philadelphia: W. B. Saunders Company, 1994. P. 1173.

SILVA, G. C. A. Análise cinemática da marcha de cães da raça Golden Retriever saudáveis, 2005; 81 f. Dissertação (Mestrado de Ciências) - Faculdade de Medicina Veterinária e Zootecnia da Universidade de São Paulo, São Paulo, 2005.

SOUTAS-LITTLE, R. W. Kinematic evaluation of gait analysis and the assessment of lameness in the dog. The Veterinary Clinics of North America Small Animal Pratice, v. 27, n.4, p.825-839, 1997.

STANHONE, S. J.; KEPLE, T. M.; McGUIRE, D. A.; ROMAN, N. L. Kinematicbased technique for event time determination during gait. Medical and Biological Engineering and Computing, v. 28, n. 4, p.355-360, 1990. 
STROBER, J.B. Therapeutics in duchenne muscular dystrophy. The American Society for Experimental Neuro Therapeutics, v. 3, n. 2, p. 225-234, 2006.

SUWANKONG, N., MEIJ, B. P., KLAVEREN, N. J. V., WEES, A. V., MEIJER, E., BROM, W. E. V. D., HAZEWINKEL, TOKURIKI, M. Eletromyographic and joint Mechanical studies in quadrupedal locomotion: Walk. Journal Veterinary Science, v. 35, p. 43-446, 1973.

VALENTINE, B. A. Canine X-linked muscular dystrophy as an animal modelo of Duchenne muscular dystrophy: A review. Am. J. Genetics, v. 42, p. 352-356, 1992.

VALENTINE, B. A.; WINAND, N. J.; PRADHAN, D.; MOISE, N. S.; LAHUNTA, A. KORNEGAY, J. N.; COOPER, B. J. Canine X-linked muscular dystrophy as an animal model of Duchenne muscular dystrophy: a review. American Journal of Medical Genetics, v.42, n.3, p.352-356, 1992.

VALENTINE, B. A.; BLUE, J. T.; SHELLEY, S. M.; COOPER, B. J. Increased serum alanine aminotransferase activity associated with muscle necrosis in the dog. Journal of Veterinary Internal Medicine, v. 4, n. 3, p. 140-143, 1990.

VALENTINE, B.A.; COOPER, B.J. Canine X-linked muscular dystrophy: selective involvement of muscle in neonatal dogs. Neuromuscular Disorders. v. 1, p. 31-38, 1991.

VAN DEN BORGERT, A.; VAN WEEREN, P.; SCHAMHARD, H. C. Correction for skin displacement errors in moviment analysis of the horse. Journal of Biomechanics, v. 23, n. 1, p. 97-101, 1990.

WALTER, R. M.; CARRIER, D. R. Ground forces applied by galloping dogs. Journal of Experimental Biology, v. 210, p. 208-216, 2007.

WANG, J.; FORST, J.; SCHODER, S.; SCHODER, M. Correlation of muscle fiber type measurements with clinical and molecular genetic data in Duchenne muscular dystrophy. Neuromuscular Disorders, v. 9, n. 3, p. 150-158, 1999.

WILLMANN, R.; POSSEKEL, S.; DUBACH-POWELL, J.; MEIER, T.; RUEGG, M. A. Mammalian animal models for Duchenne muscular dystrophy. Neuromuscular Disorders, v. 19, n. 4, p 241-249, 2009.

WINGFIELD, C. H. T.; STEAD, A. C. Canine kinematic practice hind leg gait analysis using a microcomputer. Journal of Small Animal Practice, v.34, n.7, p.319-324, 1993.

WINTER, D. A. Biomechanics and motor control of human movement. 26. ed. Ontario: University of Waterloo, 1990. p.11-212.

YAMAZAKI, M.; MINOTA, S.; SAKURAI, H.; YAMADA, A.; KANAZAWA, I.; KAWAI, M. Expression of transforming growth factor- $\beta 1$ and its relation to endomysial 
fibrosis in progressive muscular dystrophy. American Journal, v. 144, p. 221-226, 1994.

ZIMOWSKI, J. G.; HOLDING, M.; FIDZIAŃSKA, E.; FIDZIAŃSKA, A.;

RYNIEWICZ, B.; DOBOSZ, I.; HAUSMANOWA-PETRUSEWICZ, I.; KOSTERAPRUSZCZYK, A.; ZDZIENICKA, E.; KUBALSKA, J.; ANDRZEJCZYK, A.; ZAREMBA, J. Detection of rare mutations in the dystrophin gene. Med Wieku Rozwojowego, v. 13, n. 2, p. 140-145, 2009. 